\title{
CONTROLLED HEAT STRAIGHTENING FOR THE ROLLING STOCK STRUCTURES TO RESTORE THEIR SERVICEABILITY
}

\section{Collective monograph}

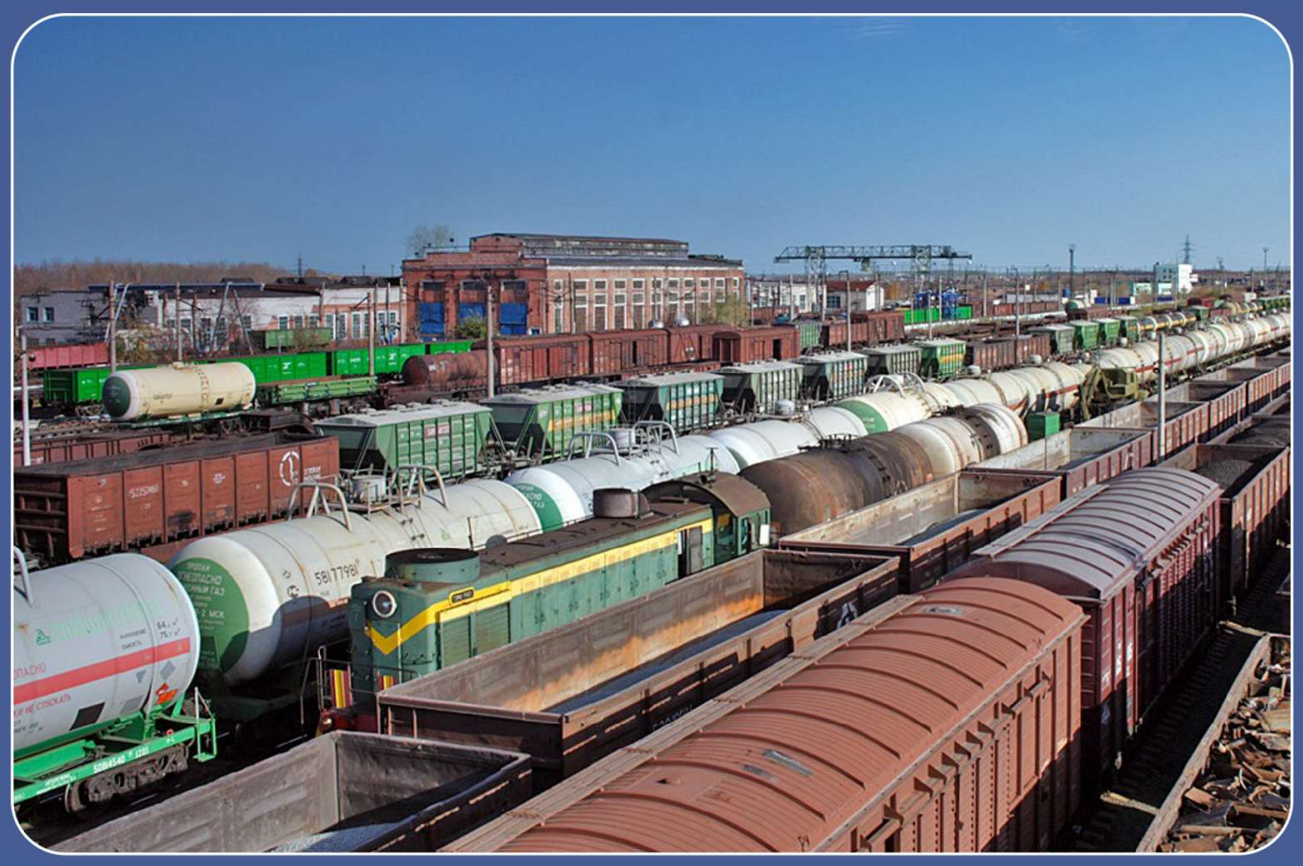

Anisiia Tomanek OSVČ 

Oleksii V. Fomin,

Mykola I. Gorbunov,

Oleksii V. Burlutski,

Olga O. Ievsieieva,

Anna M. Fomina,

Volodimir S. Nozhenko

\title{
CONTROLLED HEAT STRAIGHTENING FOR THE ROLLING STOCK STRUCTURES TO RESTORE THEIR SERVICEABILITY
}

\author{
Monograph
}

Ostrava, Czech Republic

2021 



\section{Authors}

Oleksii V. Fomin, Mykola I. Gorbunov, Oleksii V. Burlutski, Olga O. Ievsieieva, Anna M. Fomina, Volodimir S. Nozhenko

Published by Anisiia Tomanek OSVČ

Controlled heat straightening for the rolling stock structures to restore their serviceability. Hlučín: Anisiia Tomanek OSVČ. - 2021. - 119 p.

\section{ISBN 978-80-908088-7-4}

DOI 10.47451/book2021-09-01

The monograph presents the theoretical and methodological basis of the controlled heat straightening techniques for the rolling stock structures (particularly, wagons) and their prospective implementation in engineering industry. Specifically, it is concerned with a range of fundamental and applied problems of straightening distortions (occurred in the processes of production, repair and operation in structural components of the rolling stock) by applying controlled heat straightening.

The monograph is for specialists in the field of transport engineering, the information presented can be of interest for design engineers, developers, researchers, and post graduate students. Moreover, it can be used as a textbook for graduate students of rail transport engineering.

The recommended APA7 citation for this publication is:

Fomin, O.V. et al. (2021). Controlled heat straightening for the rolling stock structures to restore their serviceability. Hlučín: Anisiia Tomanek OSVČ.

(C) Anisiia Tomanek OSVČ, 2021

(C) The collective of the authors 



\section{ABSTRACT}

The monograph presents the theoretical and methodological basis of the controlled heat straightening techniques for the rolling stock structures (particularly, wagons) and their prospective implementation in engineering industry. Specifically, it is concerned with a range of fundamental and applied problems of straightening distortions (occurred in the processes of production, repair and operation in structural components of the rolling stock) by applying controlled heat straightening.

The monograph scientifically substantiates the promising trends in the technological advancement of the production and repair processes of rolling stock and analyses the techniques used for investigation of temperature fields, distortions and stresses. It describes reasons for residual stresses and distortions in the freight wagons elements during their service life, and rational approaches to their elimination. Heat straightening as an afterwelding treatment for wagon metal structures has been described.

The study presents special aspects of the straightening process for the basic open wagon elements (center sill and top cord with technological distortions) by applying heat smooth straightening, called the wedge-shape heating. The generalized three-factor mathematical model (obtained through the mathematical planning of the experiment) is used to describe a change in the basic factor (beam deflection) depending on variation of the controlled variables presented by the geometrical parameters of a wedge (width and height), and the heating temperature. The additional diagrams (binary sections) demonstrate the contour lines of deflection (lines of equal values). According to the results of these diagrams the optimal values of the wedge dimensions and the heating temperature were found; they may be used for elimination of deflections in the above-mentioned basic elements of open wagons in production.

The finite element model of the top cord of an open wagon was built, and the results of the modelling of the heat straightening techniques conducted by means of the special module Cosmos of the SolidWorks software were compared with the experimental research on determination and elimination of residual weld distortions on the full-scale specimen.

The structural and physical transformations in the bearing structures of freight wagons due to thermal welding and heat straightening were described. The study presents the results of the research of the metal structure in the heating zone before and after heat straightening, along with its mechanical characteristics. 
The results and special features of the work in restoration of serviceability of the rolling stock structures by applying controlled heat straightening have been published in some Ukrainian and international journals, discussed, and received approval at some international scientific and technical conferences.

The heat straightening techniques proposed for the bearing structures of freight wagons will be effective for other metal structures of transport and mechanical engineering.

The monograph is for specialists in the field of transport engineering, the information presented can be of interest for design engineers, developers, researchers, and post graduate students. Moreover, it can be used as a textbook for graduate students of rail transport engineering.

Keywords: transport mechanics, engineering, railway transport, rolling stock, distortion, straightening techniques. 


\section{CONTENTS}

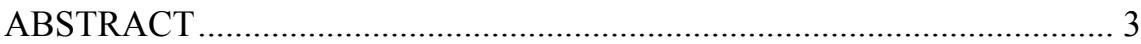

LIST OF ABBREVIATIONS ................................................................ 7

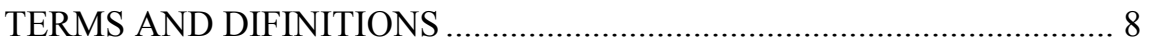

CHAPTER 1 ANALYSIS OF TEMPORARY STATE OF THE PROBLEM OF POST-WELDING DEFORMATIONS OF FREIGHT WAGON CARRYING STRUCTURES ............................................... 9

1.1 Analysis of implementation of welded joints in production and maintenance of freight wagons .......................................................... 9

1.2 Review of existing methods for determination of welding deformations in carrying welded structures of freight wagons.............. 13

1.3 Analysis of deformations in structural components of freight

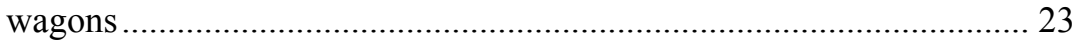

1.4 Methods to control welding deformations and stresses .................. 28

1.5 Classification of straightening methods for wagon structures and advantages of thermal straightening ................................................... 33

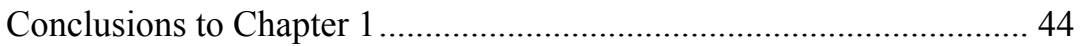

CHAPTER 2 HIGHER EFFICIENCY OF THERMAL

STRAIGHTENING WITH GENERALIZED UNIVERSAL

MATHEMATICAL NOTATION OF THERMAL STRAIGHTENING

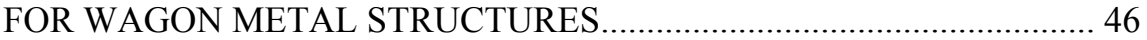

2.1. Physical nature and peculiarities of use of thermal straightening for wagon metal structures.................................................................. 46

2.2 Mathematical modelling of thermal straightening for wagon metal structures by optimality criterion....

2.3 Mathematical modelling of straightening processes in open

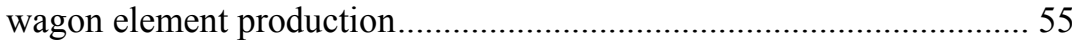

2.4. Rationale for choosing forms and geometrical parameters of heating zones under thermal straightening for wagon metal structures 
2.5 Computer modelling of straightening process with application of designed mathematical dependencies ............................................... 69

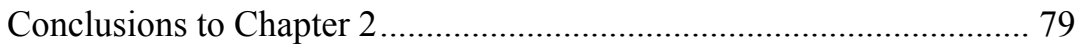

CHAPTER 3 COMPUTATION AND EXPERIMENTAL RESEARCH INTO THERMAL STRAIGHTENING OF WAGON STRUCTURES ....... 81

3.1 Organization of experimental research ....................................... 81

3.2 Experimental research into thermal straightening with local

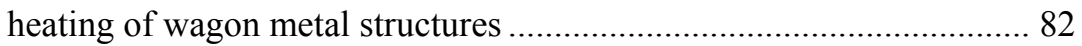

3.3 Optical microscopy for research into metal structure in heating

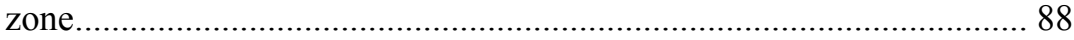

3.4 Determination of mechanical characteristics in heating zone......... 93

3.5 Cost-benefit analysis of improved technology implementation for production and maintenance of freight wagons .............................100

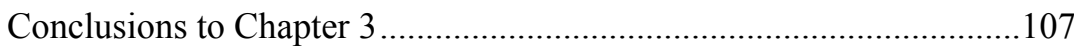

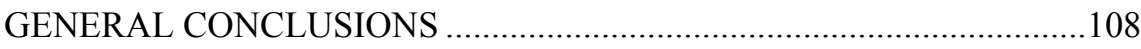

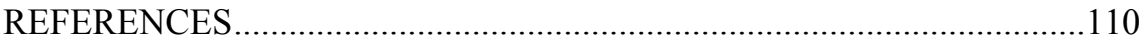




\section{LIST OF ABBREVIATIONS}

$\begin{array}{ll}\text { WM } & \text { Wagon Manufacturer } \\ \text { CSFW } & \text { Carrying Structure of Freight Wagon } \\ \text { TS } & \text { Thermal Straightening } \\ \text { WMW } & \text { Weld Metal Weight } \\ \text { FEM } & \text { Finite Element Method } \\ \text { DFEM } & \text { Design Finite Element Model } \\ \text { OD } & \text { Optimization Design } \\ \text { FR } & \text { Feasible Region } \\ \text { SSB } & \text { Stress-Strain Behaviour } \\ \text { TS } & \text { Technical Standards } \\ \text { GMM } & \text { Generalized Mathematical Model } \\ \text { TF } & \text { Target Function }\end{array}$




\section{TERMS AND DIFINITIONS}

Straightening is a technological operation consisting of generation of plastic deformations in compression zones by constant loads. It requires various presses or rolls for long objects, e.g. pipes or I-beams, for generating deformations when needed.

Thermal straightening with local heating is conducted with a gas flame or a carbon arc as a local heating source. The heating temperature is $700-900^{\circ} \mathrm{C}$, as it is favourable for plastic deformations on the deformed area. This method is widely used in production, as it is simple, convenient, precise, and cheap, and can straighten both general and local deformations.

Cold straightening is fulfilled with a force impact on the presses with hydraulic, pneumatic, mechanic or manual drives. Welding deformations emerge during welding process and remain after cooling the structure.

Thermal stresses are mechanic stresses between macro- and microelements of a solid body as a result of internal forces conditioned by heat impact and generate deformations.

Welding thermal stresses are internal stresses emerging after welding and during cooling.

Residual welding deformations are changes in forms and sizes of a detail under internal and external forces during a thermal welding cycle.

Residual welding stresses are inner stresses emerging during a thermal welding cycle, as a result of thermoplastic deformations and structural transformations on certain areas (generally, near and in joints). 


\section{CHAPTER 1 \\ ANALYSIS OF TEMPORARY STATE OF THE PROBLEM \\ OF POST-WELDING DEFORMATIONS OF FREIGHT WAGON CARRYING STRUCTURES}

\subsection{Analysis of implementation of welded joints in production and maintenance of freight wagons}

The main technological process in production and maintenance of freight wagons (e.g. open wagons) is welding. Nowadays the most important condition to improve the welding process is not only development of fundamentals of the welding process based on advanced achievements in different branches of fundamental and applied sciences, but also creation of highly effective techniques and methods of modelling and simulation of welding processes. Application of mathematical methods and mathematic modelling for welding processes has become a powerful instrument for research and study of processes running in complex technological systems; it allows the specialists to obtain a formalized description of their basic dependencies and to learn how to control them most efficiently. The mathematical modelling can optimize conditions of welding processes, avoid emergence of intolerable defects in welded joints for the structure, and simultaneously increase efficiency of welding operations. Therefore, higher labour efficiency and lower production cost have always been in the center of attention for any production. Similarly to other technological processes, welding greatly influences the technical level of many industries, particularly, the wagon production, which is testified in the studies presented [1,2].

Successes in welding science and engineering have broken a new ground in the wagon building, created brand new highly-efficient freight wagon structures, increased labour efficiency of production [3].

Application of welding has considerably facilitated the whole process, increased strength and decreased labor efficiency. Production and maintenance of metal structures of freight wagons require welding for joining their elements. Most metal structures must meet high requirements for strength, reliability and operability. Therefore, the comprehensive and complete estimation of strength, reliability and operability of carrying structures of freight wagons requires sufficient information on the stressstrain behavior of metal, not only on critical sections, but also in stress concentration areas where cracks emerge and develop [4]. 
For welded structures such stress concentrators are various technological defects emerging under welding, and transition areas between joint and base metal. Presence of such stress concentrators, particularly in most loaded zones, considerably decreases the strength and the operational capacity of a structure. Special attention is given to rolling stock units, as they are the key element of traffic safety for passengers, staff, and security of the cargo transported. Welded joints of wagon structures in comparison with other machine building structures have some peculiarities in terms of loads and operational conditions regarding various climatic zones. The research into the processes of crack emergence and development demonstrates that considerable plastic deformations are running in the stress concentration areas before damage in the local areas; it results in creation of dissipative structures generating this damage.

A fundamental contribution to estimation and increase of the strength and reliability of wagon structures was made by E.P. Blokhin, Yu.P. Boronenko, S.V. Vershinsky, O.V. Fomin, V.M. Danilov, I.P. Isaev, M.O. Kostenko, K.P. Koroliov, V.M. Koturanov, L.D. Kuzmich, O.S. Lisovsky, V.P. Lozbinev, B.A. Meisner, E.M. Nikolsky, L.M. Nikolsky, M.M. Ovechnikov, A.P. Prikhodko, A.I. Rechkalov, A.M. Savoskin, O.M. Savchuk, M.M. Sokolov, V.D. Khusidov, L.A. Shadur, M.M. Shaposhnikov and others.

The problems of higher strength of materials and welded structures were thoroughly studied in research by A.E. Andreikin, G.S. Vasilchenko, V.A. Vinokurov, P.M. Vitvitsky, A.G. Grigoriants, V.F. Demchenko, V.S. Ivanova, V.A. Karkhin, S.N. Kiseliov, V.L. Kolmogorov, L.A. Kopelman, A.Ya. Krasovsky, S.A. Kurkin, V.I. Makhnenko, M.A. Makhutov, O.M. Morozov, V.F. Lukianov, G.A. Nikolaev, V.A. Osadchuk, V.V. Panasiuk, V.Z. Paton, G.S. Pisarenko, Ya.S. Podstrigach, N.M. Prokhorov, O.M. Romaniv, V.I. Savchenko, V.I. Trufiakov, G.P. Cherepanov, A.O. Chizhik, D.M. Shur, S.Ya. Yarema, D. Dugdale, R. Dolby, T. Ekobori, D. Irwin, F. McClintock, D. Nott, D. Rice, D. Si, A. Wells, F. Erdogan, D. Eshelby, V.Kh. Munze, R. Olivir, Zh. Vocney, J. Cravmer, V. Langenekker, A. Solokian and others.

All modern wagon types in service in the rail transport are complex welded spatial structures of different rigidities, intercrossed and joined (e.g. center sill, cross beam, poles, etc.), of various spatial location, mutually intercrossed, most popular of which are welded T-joints. Such welded joints and structural forms can create considerable stress concentrations and, thus, greatly impact the strength and the reliability of a wagon. Besides, it should 
be mentioned that freight wagon elements are produced with virtually all known types of welded joints.

The most complicated welded assemblies of freight wagons, which are subjected to considerable damage in operation are locking angles of corner posts and side stakes of open wagons, cross unit of the frame, linking beams of heavy eight-axle wagons, truss joints of side wall of a box car, frame and body of a tank wagon. Besides, there are a lot of welded joints in other assembly units and wagon elements.

The welding technological process increases strength of products and reduces labour intensity. All over the world welded elements have structurally been improved and the welding process has been automated. A number of scientific and technical publications in Ukraine and other countries [5] have demonstrated that research and design studies dedicated to improved welding technology and optimization of welded structures in wagon building are continuing.

Among lines of research in wagon production mentioned in the studies above are the following: research of structural properties of joint metal and the appropriate area of thermal impact under welding; development of methods aimed at determination and further decrease of stresses and deformations in welded structures; research into strength characteristics of joints and metal properties; study of changes in strength properties of metal under cyclic loading; improved methods of mechanization and automation of welding processes in production and maintenance of wagons.

Nowadays welded structures are basic carrying and frame elements in wagon production. Among main types of existing welded structures in modern railway wagons are beams, frames, floors, side and end walls, doors, roofs and tank shells. The structures of welded assemblies of wagons and their production technologies are constantly improving.

In production and maintenance of open wagons, welding processes account for about $80 \%$ of all works. As far as the strength of an open wagon is defined by the rational combination of characteristics of materials used, geometry of details and assemblies, technological production and maintenance processes, and operational conditions, the specialists involved in the development and maintenance of open wagons must give considerable attention to a further increase of operational efficiency of wagons. And special attention should be paid to welded joints because the main reason when an open wagon must be send to uncoupling and scheduled repairs is fatigue damage of its elements along with plastic deformations in metal crystals, which generates fatigue cracks after two or three years of service. It 
was established that about $90 \%$ of fatigue cracks is located in welded joints, which generated initial defects and damages [6, 7]. Besides, it should be mentioned that welding-on various pads, patches, joints and other details as part of roundhouse servicing of main assemblies for an open wagon during its service life increases the labour intensity four times in average, and current/scheduled repairs of an open wagon require about 12 tons of metal, thus twice exceeding its tare weight [8].

At present the electric arc welding (half-automatic, manual or flux) is widely used in production and repair of freight wagons. This welding is characterized by fast local heating, conditioned by an impact from a concentrated heating source (which makes the metal on welding area plastic and liquid), with comparatively quick cooling of the area. And the result of it is temporary and residual welding stresses in the structure. The temporary stresses can be seen only under welding with change in temperature, and, generally, disappear after cooling. The residual stresses remain in the welded structure after welding, complete cooling and taking fixation loads off.

There are such residual stresses according to the length and physical nature of the stress field: Stresses of $1^{\text {st }}$ kind (macro-stresses balanced within the zones comparable to the dimensions of a product); Stresses of $2^{\text {nd }}$ kind (micro-stresses balanced within the metal grain size); and Stresses of $3^{\text {rd }}$ kind (sub-micro-stresses balanced within several interatomic distances). Generally, welded structures of low-carbon and low-alloyed steels undertake welding stresses of the $1^{\text {st }}$ kind, while some welded alloy and high-alloyed steels can suffer from stresses of the $2^{\text {nd }}$ and the $3^{\text {rd }}$ kinds. And there are several welding stresses according to spatial location and interaction: linear single-axis, two-dimensional - two-axis, three-dimensional - three-axis; and by direction of action: longitudinal - parallel to the weld axis, and transverse - perpendicular to the weld axis. Residual welding stresses appear after welding and taking fixation off the welded structure. Along with that, the stress-strain behaviour of a structure re-distributes, residual deformations emerge, and internal stresses also re-distribute [9].

The main reason for residual welding deformations in freight wagon elements is formation of the so-called heat-effected or plastic zones. Therefore, research into dependencies under formation of heat-effected zones and reasons for that, study of residual deformations and displacements, development of techniques to regulate and control them is at present of primary importance for wagon production. Besides, residual welding stresses, as known, increase the potential energy accumulated in the structure, which intensifies negative effects of fatigue damage $[10,11]$, and in operation the 
residual deformations and stresses decrease strength, corrosion stability and accuracy of a welded structure.

Conventional methods to decrease these stresses, such as an increase of the metal thickness, stabilization of post-welding works, and elimination of allowances do not always meet the up-to-date requirements for energy consumption, labour intensity and metal capacity of a structure. As far as each existing welding technique does not ensure zero-defect welded joint, post-welding treatment of joints has been widely used in the world in recent years; it implies to straightening methods which can renew the detail geometry after welding [12].

\subsection{Review of existing methods for determination of welding deformations in carrying welded structures of freight wagons}

A wide use of welded structures in wagon production has made it possible to distinguish problems of negative effects of stresses and deformations emerging under welding and affecting the carrying capacity of freight wagon elements. Among the methods used for determination of such stresses and deformations are:

- grapho-analitical, based on the plane-section hypothesis and assumptions of one-dimensionality of a high field by G.A. Nikolaev [13], later studied by N.O. Okerblom [14], V.P. Vologdin, K.M. Gatovsky [15] and other specialists. A disadvantage of the graphic-analytical methods is their restriction to one-dimensional problems;

- analytical methods with the mathematical apparatus of the theory of elasticity and plasticity. The appropriate mathematical tool presented in studies by B.S. Kasatkin, L.M. Lobanov [16] was used to determine an uneven temperature distribution and stresses during welding processes. At the same time the analytical research into welding stresses and deformations with the use of this apparatus is restricted to the models, which consider the development of elastic-plastic deformations in the technological welding process as ideal;

- numerical methods with the use of the theory of elasticity and plasticity $[17,18]$. These methods allow calculation of stresses and deformations during a free temperature distribution by the law set analytically or numerically with computers. The combination of numerical methods and modern computer means has proved their potential for calculation of welding stresses and deformations; 
- computational and experimental. The use of them gives consistent results in terms of actual welded joints regardless welding patterns;

- experimental [19], for determination of welding stresses and deformations directly on welded objects, such as samples or models. And the main feature in determination of welding stresses and deformations is a need to conduct experiments in high temperature areas.

These methods helped establish a number of basic dependencies in creation and distribution of welding stresses and deformations for modern structures. However, due to the complicated nature, there is no single method for determination of welding stresses and deformations. Most researchers believe that plastic deformation accounts for $2 \%$ of the weld line length in average. It testifies that the reason for deformation causing changes in the metal structure is a plastic deformation zone. Thus, development of stresses and deformations in the weld bath area depends on main and additional factors. Among the main ones are: temperature gradient, metal stiffness, initial state of the metal, type of welded joint and external ties. The role and the impact of a certain factor are complex and have to be considered for each particular case $[2,4,12,32]$.

Welding deformations and stresses lead to deflections in geometrical forms and dimensions from the design ones, which increase the labour intensity in production of a welded structure, decrease operational characteristics, worsen stability and carrying capacity, complicate assembly of certain units, or even make this assembly impossible. Thus, one of the most important problems in production of welded structures is determination of welding deformations and stresses which affect the operational performance of welded joins and structures very differently.

The problem of internal and residual stresses under heating of metal during welding was firstly outlined by Russian steel worker N.V. Kalakutsky as early as in 1887. In his study "Research into internal stresses in iron cast and steel" N.V. Kalakutsky demonstrated that such stresses had of a wide boundary range. Thus, a design engineer must consider them and recommend some reliable methods for their regulation and control.

The most popular methods for determination of welding deformations are calculation methods based on the theory of thermal plasticity, and approximate calculation methods. At the same time experimental methods are rarely used for prediction of welding deformations in large structural systems. They are mostly used for estimation of fabricated structures according to different input parameters. And on the basis of such experimental data it is possible to construct corresponding parameter-oriented 
prediction models. Some well-known studies [20, 21] use the approaches based on neural networks; it means that the corresponding computer database includes a selection of experimental data with consideration of a certain variation of output parameters, and on the basis of them the computer program generates the solution which, by far, has some restrictions regarding prediction of deformations emerging during welding of metal structures of large overall dimensions.

At present existing methods for determination of welding stresses and deformations are based on mathematical modelling of physical processes forming the stress-strain behaviour during welding which is similar to the residual state. Thus, welding process actuates changes in the metal microstructure, forms temperature fields, mechanical and thermal-physical properties, and also stress fields leading to elastic plastic deformations. It should be mentioned that this approach is of interest for many scientists and researchers all over the world.

Historically, a great contribution to the analysis of thermal mechanical processes during welding was made by Soviet scientists [22, 23] as early as in 1960s, which is shown in the studies on the subject. Unfortunately, the findings were not presented in other countries because of the language barriers. For example, European countries could read the academic papers of M.O. Okerblom, V.A. Vinokurov and V.I. Makhnenko only when they were translated into English many years later $[24,25,26]$. Thus, we can witness that researchers from Western countries, and Japanese specialists [27, 28] presented the results, which were obtained by Soviet scientists $10-20$ years before. However, developments of scientists from Western countries were of higher quality due to application of computer technologies and up-to-date methods. Soviet scientists used various approaches for prediction and computation of welding stresses and deformations. The approach based on thermal plasticity was classical. It was developed and presented in study [14] by N.O. Okerblom. At the same time, the prediction methods for residual stresses and deformations based on the use of material shrinkage which accompanies welding of certain joints were in good progress [29]. These approaches can be classified as approximation methods based on the shrinkage function of welded joints. E.O. Paton along with co-workers was the founder of the trend to consider the shrinkage function [30]. It should be mentioned that his work published as early as in 1936 is still used and of scientific and practical interest, as far as his idea to use the computational estimation of residual welding deformations with methods of the theory of elasticity through a set value for experimental shrinking deformations (simple tests) is now widely referred to in many studies. 
Scientific and technical literature presents a great variety of methods for measurement of welding deformations according to the purpose. And there is a difference between measurements of welding deformations in the metal of a welded joint and measurements of displacements of certain points of a welded metal structure. At the same time temporary and residual deformations in welded joints result in development of local and general deformations in welded structures. Such local deformations as longitudinal and transverse shrinkages, angular deformations, deflections and others are insignificant by the absolute values. General deformations of welded structures, among which are shortenings, deflections and torsions, as well as some types of local deformations, which can appear as displacements of certain points can reach considerable values. Existing experimental methods for measurement of local and general welding deformations differ by range and measuring accuracy. They can be measured either in one point of a welded structure or along a specific length. Therefore, measuring methods of deformations can principally differ.

The traditional measurement of residual displacements is fulfilled with standard measuring instruments and detecting heads [22]. Displacements of small structures are determined by measurements on the plate (Fig. 1.1, a), and large ones - with a stretching string (Fig. 1.1, b). And such deformations as cambers are determined with a portable stiff linear (Fig. 1.1, c). For this reason one should place it on the structure and transfer the detecting head which will record displacements of isolated points (Fig.1.1, d). The detecting head can also be fixed on the mount pillar moving on the plate. Sometimes deflections can be measured with a special device of prisms and a detecting head (Fig. 1.1, f).
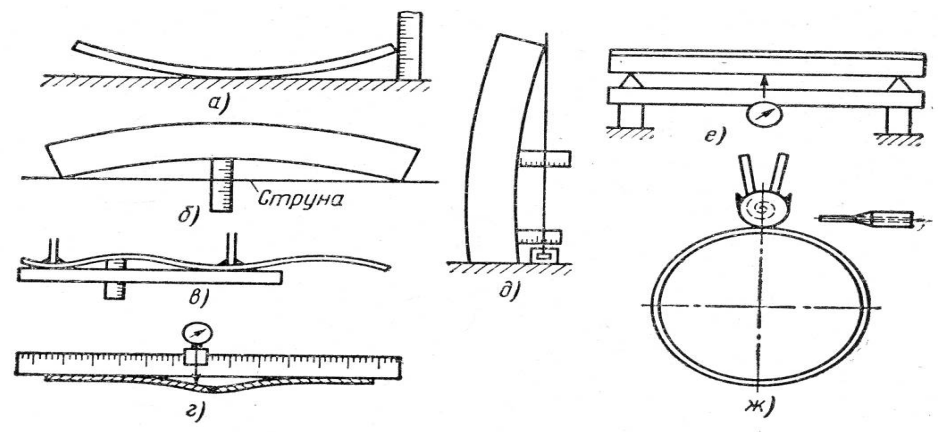

Fig. 1. 1. Measuring diagrams of residual displacements in welded structures 
Displacements (deflections) of such welded elements as pillars, can be measured with a weighted string submerging in a bath with a liquid which absorbs oscillations (Fig. 1.1, e). Perimeters can be measured by stretching the string around (Fig. 1.1, g).

It is crucial that the method can be used for determination of the deformation kinetics during welding (cooling) with the appropriate record of measuring results. A special feature in terms of measuring deformations during welding is high temperature. Therefore, there is a need to use either thermal resistant electric tensometers, or mechanical tensometers with heateliminating legs (Fig. 1.2, a, b). It is more convenient to measure displacements of some points relative to a certain reference point on the detail being welded and located outside the zone of considerable displacements. In the measuring diagrams (see Fig. 1.2, c, d, e) the reference points are on the cold metal. The reference starting point can lie on the device, e.g. when measuring displacements of the plate edges in the vertical direction (Fig. 1.2, e, f), or on the backing ring for measurements on the edges of a shell in radial direction (Fig. 1.2, g).

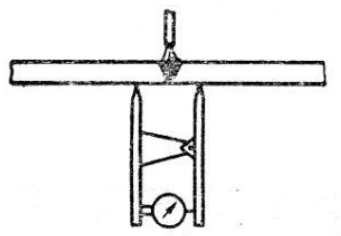

a)
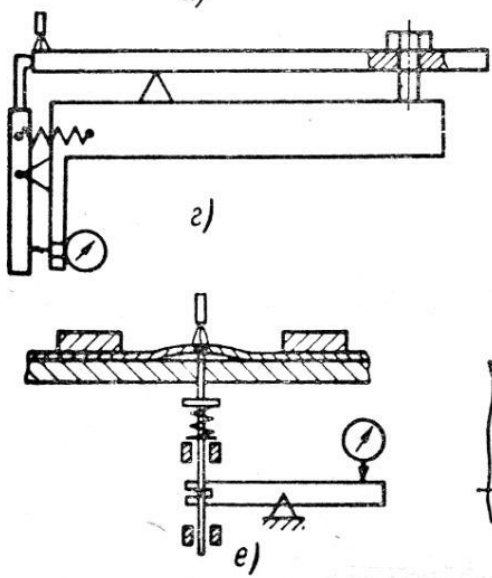

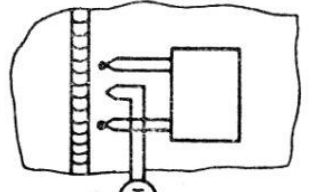

(T)

ठ)
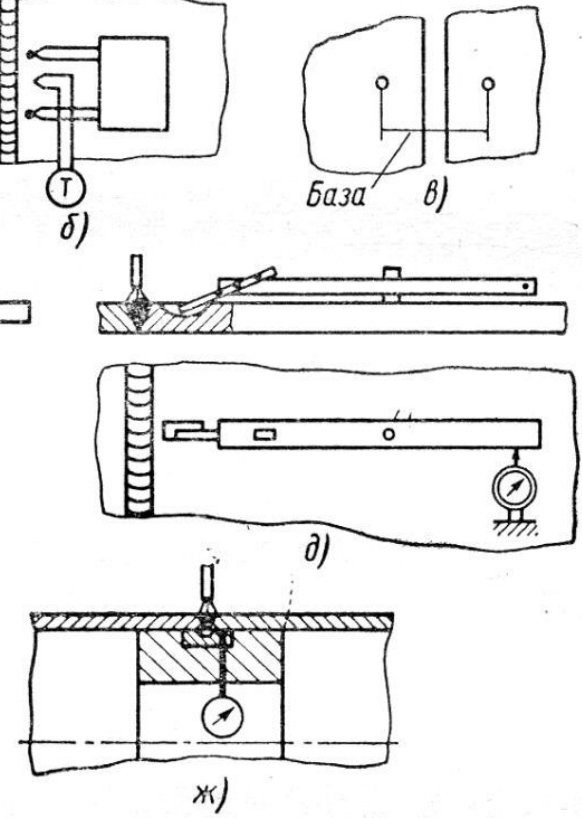

Fig. 1.2 Measuring diagrams of deformations and displacements under welding process 
The measurements with optical and mechanical tensometers are widely used for experimental research into the stress-strain behavior of welded metal structures; they differ structurally and by design according to type, measuring accuracy, measurement range, and also complexity of the metal structure under study. Their basic operational principle is to determine a change in the base restricted by the read-out elements of a tensometer [31]. The structure of mechanical tensometers establishes a rather high (no less than 10-20 mm) minimal gauge length. In practice transverse and longitudinal shrinkage of welded joints, and angular deformations can be measured with mechanical tensometers. Such measurements are taken before and after welding with marked gauge lengths.

The indicating tensometers are widely used for experimental research (Fig. 1.3) [23]. Their operational principle is based on the lever of the first kind, which is placed in the reference holes (see Fig. 1.4); it takes the deformation and transfers it to the movable indicator bar. The accuracy of such tensometers depends on the accuracy of their indicators and can be increased by changing a ratio of scale arms.

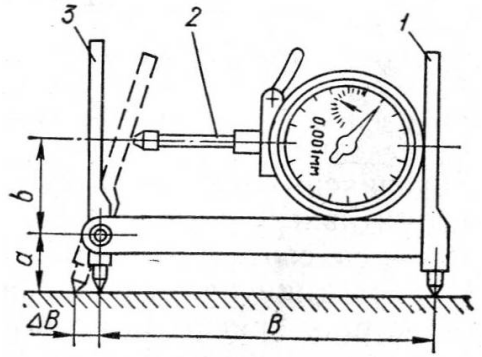

Fig. 1.3. Diagram of indicating tensometer:

1- rigid lever;

2 - indicator bar;

3 - moving lever
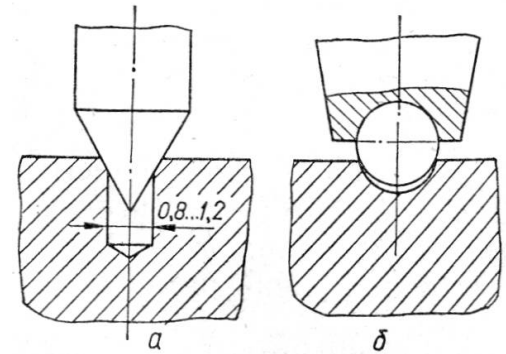

Fig. 1.4. Installation of measuring levers of strainmeters in reference holes (a) and on sphere marks (b)

The structure of mechanical tensometers is based on a lever or a system of levers. The gauge length of a measuring device depends on the scale of magnification and the required sensitivity. The mentioned tensometers are used for static and dynamic measurements. Besides, they can be fixed on the object under study during the whole testing time, or only for measuring, therefore, they can be removed later. Mechanical tensometers can also be used for measuring the deformation kinetics. But their use for experiments on 
welding deformations is restricted as far as they use an obsolete method for recording results, and the measuring accuracy depends on the human factor.

Analysis of research methods for temperature fields and appropriate deformations and stresses

Analysis of some areas of the base metal of welded structures of freight wagons demonstrated that in the areas where they border the melting zone there appear considerable changes both in properties and in metal structure. The basic reason for these changes is heating of the metal of a heat-affected zone to high temperatures with subsequent gradual cooling with simultaneous effect from appearing stresses and plastic deformations.

A quality welded joint requires an appropriate welding (or fusing) mode which provides conditions for the optimal structural and phase transformations for further obtaining the needed properties of material in the heat-affected zone. Therefore, development of special methods to research into phase transformations in materials affected by heat under conditions similar to the actual welding process is of primary attention of specialists in the field.

One of the first techniques used for studying phase transformations in metals is a bead-on-plate test developed by M.M. Rikalin and L.O. Fridliand; for many years it has been used for studying the structure and properties of material in the heat-affected zone, and for selecting the technology and mode of welding [32].

In his work [33] V.A. Riapolov considered a change in temperatures in the cross-cuts of a tank wagon; this change is of non-linear nature, which must lead to appearance of high stresses in sections of the carrying structure.

The thermal kinetic diagrams give the most comprehensive knowledge of the processes during continuous cooling. On the basis of a number of research dilatometers were designed; they allow researchers to obtain continuous cooling transformation (CCT) diagrams during welding. M.Kh. Shorshorov and V.V. Belov generalized an extensive material on CCT diagrams of different steels in collection of maps [34]. On the basis of CCT diagrams it is possible to establish speed limits for steel cooling, which are most favourable in terms of structure and hardness of the heat-affected zone of welded joints. These techniques were used in the reasoned research into aging and properties of the heat affected zone of welded joints for different steel grades.

By the data presented by A.I. Akulov [35], the heat-affected zone for low-carbon and low-alloyed steels have some areas of diverse structure and mechanical properties. The metal area heated to the temperature interval 
between solidus and liquidus forms an incomplete fusing area. This area consists of partially fused grains with thin layers between them. Therefore, the metal composition of this zone can differ from the composition of the base metal and the joint metal. The length of this area is small and usually does not exceed $0.5 \mathrm{~mm}$, but the properties of its metal often affect the properties of the whole welded joint.

Metal heated from the temperature $1100 \ldots 1150^{\circ} \mathrm{C}$ to the solidus curve forms a superheated zone. Here we can see a growth of the austenite grain, the size of which increases with an increase of the metal temperature. The coarse metal structure on this zone can lead to formation of the unfavourable structure. Metal slightly heated over temperatures $\mathrm{A}_{\mathrm{C} 3}$ forms a normalization (re-crystallization) zone. This zone is of fine-grain texture and good mechanical properties. On the incomplete re-crystallization area metal is heated to the temperature between $\mathrm{A}_{\mathrm{C} 1}$ and $\mathrm{A}_{\mathrm{C} 3}$. Therefore, it is characterized by a practically uniform ferrite grain, slight grain refining and spheroidization of perlite zones. Metal heated in a range of temperatures from $500-550{ }^{\circ} \mathrm{C}$ to $\mathrm{A}_{\mathrm{C} 1}$ forms a re-crystallization zone. Here we can witness fusion of crumbled grains and their increase. As a result, the mechanical properties of metal on this area can change. On the aging area metal is heated in a range of $100 \ldots 500{ }^{\circ} \mathrm{C}$. Its structure does not change, but heating of some steels to $150 \ldots 350{ }^{\circ} \mathrm{C}$ runs along with a sharp drop in the impact viscosity.

The structure of welded joints of freight wagons is formed under nonsteady temperatures and stresses, therefore, the properties of a welded joint depend not only on a thermal cycle but also on a deformation cycle determined by the temperature cycle and rigidity of the welded joint.

Study [36] considers the efficiency of a deformation cycle under the arc welding of wagon structures of low-carbon steel with Chernov-Lüders deformation lines which clearly reveal the welded joint zone covered with plastic deformations. It was demonstrated that a deformation cycle covers a far larger area (to $60 \mathrm{~mm}$ ), than a thermal cycle (to $25 \mathrm{~mm}$ ).

Study [37] demonstrates that the inter-grain slip processes and the intra-grain slide processes run along with accumulation of defects in the crystal grid. It is proved by findings presented by I. Hryvniak [38], who while studying the dislocation structure of a heat-affected zone, observed a relatively high dislocation density on the superheat zone of ferrite-perlite structure oriented to the Widmanstätten structure. In the normalization zone the dislocation density was slightly higher than that in the base metal, but lower than that in the superheat zone. 
The high dislocation density in a heat-affected zone indicates considerable plastic deformations (over 10\%) and poor development of the return process, which leads to accumulation of elastic energy of crystals distortions. This energy partially emits in re-crystallization, thus explaining better mechanical properties in the normalization zone. However, further heating of metal to point $\mathrm{A}_{\mathrm{C} 1}$ and lower demonstrates more intensive plastic deformations. In spite of a considerable increase in the dislocation density there is no noticeable changes in the output ferrite-pearlite structure.

According to B.E. Paton [39] it creates favourable conditions for deformation aging, which results in the above-mentioned deteriorations of the mechanical properties in this area of a heat-affected zone.

Further studies conducted in Ukraine and abroad dealt with a link between the structure of a heat-affected zone and the mechanical properties of welded joints. The researchers studied metal samples of the structure simulating that of a heat-affected zone. Thus, study [40] regards formation of the structure and properties of metal of welded joints, metal of a heat-affected zone of welded joints of low-carbon steels by samples of simulated structure. It was established that a smaller austenite grain with a ferrite zone does not considerably affect the impact viscosity.

Below is given a short analysis of important studies devoted to calculation of temperature fields and the corresponding stress-strain behaviour in element bodies, including ones which are components of transport structures.

One of the first studies dealing with temperature stresses was written by Duhamel [40], where he generalized the basic equations of the theory of elasticity for the case when the body temperature changed, and, with generalized equations he considered a number of specific examples of homogeneous isotropic, mainly symmetrical, bodies. The approach to the problem and the nature of the tasks set by Duhamel were mostly similar; he derived equilibrium equations (in stresses) and surface conditions with considerations of temperatures, used dependencies between deformations and stresses, and considered isotropic bodies. Duhamel invented the concept of thermal pressure coefficient, the value of which equals the uniform external pressure needed for the body volume to be constant at a uniform increase of its temperature. For isotropic bodies they both suppose the equal coefficient in all directions; it is taken as directly proportional to the first degree of temperature. The temperature is supposed to be independent of external forces. Later studies [41, 42] developed and improved the calculation methods for temperature stresses in rotation bodies. 
B.G. Galerkin [43] considered stress distribution in rectangular, triangular and pie plates at the temperature changed only according to the thickness. Those studies and many others became the foundation for modern analytical and numerical methods of research into temperature stresses.

A great theoretical contribution to the thermo-elastic behaviour was made by A.D. Kovalenko [44, 45]. In his monographs the author chose the natural and best approach, i.e. he built the theory of thermal elasticity based on the fundamental thermal dynamics laws for non-reversible processes and laws of classic mechanics. Such an approach allowed him to consider in one respect the running and interaction of mechanical and heat processes in solid bodies under deformation, and to obtain an equation system with ratios between stresses and deformations, heat-transfer equations with a component dependent on deformations, motion equation, interaction between deformations and displacements. Such a system of equations at certain initial conditions generally describes the so-called coupled dynamic thermoelasticity problem.

This approach helped clearly classified and stated the fundamental thermo-elasticity problems at big and small thermal excitations. Among the most important problems are coupled dynamic and quasi-static ones.

Taking into account the given classification, most important for practice is the uncoupled quasi-static thermo-elastic problem which describes deformation of elastic bodies regardless of inertia terms in motion equations and an effect of a deformation field on a temperature field. Numerical methods have become most popular in solution to engineering thermoelasticity problems. First of all, among these methods one should mention the finite element method (FEM), which was actively applied and formed as an effective method for a great variety of problems. Apart from its universal nature, it is illustrative and produces exact results, though it requires certain experience in discretization and powerful computers. When applied for heat conduction problems it helps consider various boundary and initial conditions, physical heterogeneity, complicated geometrical form and, thus, brings the design diagram in proximity with a real object. Besides, FEM makes it possible to solve heat conduction problems non-linearly, when thermal-physical characteristics can change according to the temperature.

Solution to the temperature problems in wagon production was considered in $[33,46]$. The study deals with plane design models, on the basis of which the authors made a numerical analysis of distribution and change of temperatures in time on eleven most typical sections of carrying and supporting structural elements of a 22-4008 open wagon for hot bulky 
metallurgical freight with consideration of cooling directly after loading. The numerical analysis demonstrated that change in temperature on sections was non-linear and led to high stresses; the maximum temperature $\left(\mathrm{T}_{\max }\right)$ for the carrying and supporting elements was not uniform, and elements of various cross-sections of beams reached it at different time under heat dissipation conditions. Thus, the center sill in the center of the wagon had $\mathrm{T}_{\max }=44^{\circ} \mathrm{C}$ at the time moment $\mathrm{t}=40 \mathrm{~min}$.

The authors developed a technique for determination of temperature stresses in welded elements of a wagon; it was based on transfer from the uneven temperature distribution on sections in the basic carrying and supporting elements of a wagon emerging due to high temperature of the freight, to the load characteristics (moments and forces) included in the loading vector.

Study [47] presents a model for the thermal loading of a temperaturecontrol car for transporting hot semi-finished metallurgical products.

\subsection{Analysis of deformations in structural components of freight wagons}

The generalized mathematical model of the stress-strain behaviour of a body, proposed by V.I. Makhnenko [39], is based on algorithms in which a temperature field is defined by formula of N.N. Rikalkin [33].

So, the general strain tensor $\varepsilon_{\mathrm{ij}}(\mathrm{x}, \mathrm{y}, \mathrm{z}, \mathrm{t})$ is given as the sum of three tensors

$$
\varepsilon_{i j}=\varepsilon_{i j}^{e}+\varepsilon_{i j}^{p}+\varepsilon_{i j}^{c},
$$

where the index e corresponds to elastic deformation; $\mathrm{p}$ - deformations of instantaneous plasticity; c-deformations of diffused plasticity or creep.

The elastic deformation tensor $\varepsilon_{i j}^{e}$ is linked with the tensor $\sigma_{\mathrm{ij}}$ by Hooke's law

$$
\varepsilon_{i j}^{e}=\delta_{i j} \varepsilon+\left(\sigma_{i j}-\delta_{i j} \sigma\right) \frac{1}{2 G},
$$

where $\delta_{\mathrm{ij}}-$ single tensor; $\mathrm{G}$ - shear modulus, and

$$
\varepsilon=K \sigma+\varphi
$$




$$
\boldsymbol{G}=\frac{E}{2(1+v)}
$$

where $\mathrm{K}$ - volumetric modulus of elasticity determined by the formula

$$
K=\frac{1-2 v}{E}
$$

where E - Young's modulus; $v$ - Poisson's ratio.

The conditions of emergence and development of plastic deformations $\varepsilon_{i j}^{p}$ are presented as formula with invariant characteristics of stress tensors. One of simple and the most popular approaches is the method based on the theory of plastic flow combined with the Cramér-von Mises criterion as

$$
\begin{aligned}
& \boldsymbol{d} \varepsilon_{i j}^{p}=\mathbf{0}, \text { provided } \mathrm{f}<0 \text { or } \mathrm{f}=0, \text { but } \mathrm{df}<0 ; \\
& \boldsymbol{d} \varepsilon_{i j}^{p}={ }_{\mathrm{B}} \lambda\left(\boldsymbol{\sigma}_{i j}-\boldsymbol{\delta}_{i j} \boldsymbol{\sigma}\right), \text { provided } \mathrm{f}=0 \text { and } \mathrm{df}>0 ;
\end{aligned}
$$

the state $\mathrm{f}>0$ is inadmissible.

Besides,

$$
\begin{gathered}
\boldsymbol{f}=\boldsymbol{\sigma}_{\boldsymbol{i}}^{2}-\boldsymbol{\sigma}_{\boldsymbol{T}}^{2}\left(\boldsymbol{T}, \boldsymbol{\omega}^{\boldsymbol{p}}\right) \\
\sigma_{e q}=\frac{\sqrt{2}}{2}\left[\left(\sigma_{x x}-\sigma_{y y}\right)^{2}+\left(\sigma_{x x}-\sigma_{z z}\right)^{2}+\left(\sigma_{y y}-\sigma_{z z}\right)^{2}+6\left(\sigma_{x y}^{2}+\sigma_{x z}^{2}+\sigma_{y z}^{2}\right)\right]^{0,5},
\end{gathered}
$$

where $\sigma_{\mathrm{eq}}$ - equivalent stress intensity;

$\sigma_{\mathrm{s}}\left(T, \omega^{\mathrm{p}}\right)-$ deforming stress on the loading surface $\mathrm{f}=0$;

$\omega^{\mathrm{p}}-$ mechanical hardening parameter;

$\mathrm{d} \lambda$ - scalar function.

The technique proposed by V.I. Makhnenko makes it possible to define the speed of welding stresses and deformations with numerical methods. However, this technique does not consider phase-transition heat and dependency of thermal-physical coefficients on temperature, and also has the error of the method of numerical differentiation, which considerably worsens its accuracy at determining high-temperature changes.

However, there is an alternative way, i.e. determination of the residual stresses and deformations with A.A. Ilyushin's theorem of unloading as follows 
1. Solution to the elastic-plastic problem

$$
\begin{aligned}
& \left\{\begin{array}{c}
\frac{\partial \sigma_{11}}{\partial \mathrm{x}_{1}}+\frac{\partial \sigma_{12}}{\partial \mathrm{x}_{2}}=0 \\
\frac{\partial \sigma_{21}}{\partial \mathrm{x}_{1}}+\frac{\partial \sigma_{22}}{\partial \mathrm{x}_{2}}=\mathbf{0}
\end{array}\right. \\
& \frac{\partial^{2} \Delta \varepsilon_{11}}{\partial x_{2}^{2}}+\frac{\partial^{2} \Delta \varepsilon_{22}}{\partial x_{1}^{2}}=\mathbf{2} \frac{\partial^{2} \Delta \varepsilon_{12}}{\partial \mathrm{x}_{1} \partial \mathrm{x}_{2}} ; \\
& \left\{\begin{array}{c}
\sigma_{11}\left(M^{I}\right) n_{\mathbf{1}}+\sigma_{12}\left(M^{I}\right) n_{2}=g_{1}\left(M^{I}\right) \\
\sigma_{21}\left(M^{I}\right) n_{1}+\sigma_{22}\left(M^{I}\right) n_{2}=g_{2}\left(M^{I}\right)
\end{array}\right.
\end{aligned}
$$

$\mathrm{M}^{\prime} \boldsymbol{\epsilon} \Gamma, \boldsymbol{n}_{\mathbf{1}}, \boldsymbol{n}_{\mathbf{2}}-$ directional cosines to $\Gamma$;

$$
\varepsilon_{i j}=\varepsilon_{i j}^{*}+\Delta \varepsilon_{i j}
$$

where $(*)$ - value in a previous temporary layer.

$$
\left\{\begin{array}{c}
\Delta \varepsilon_{11}=\mathrm{B}_{1} \sigma_{11}+\mathrm{B}_{2} \sigma_{22}-b_{11} \\
\Delta \varepsilon_{22}=B_{1} R_{22}+B_{2} R_{11}-b_{22} \\
\Delta \varepsilon_{12}=\psi \sigma_{12}-b_{12} \\
\Delta \varepsilon_{33}=B_{2}\left(\sigma_{22}+\sigma_{11}\right)-\mathrm{b}_{33} \\
\Delta \varepsilon_{13}=\Delta \varepsilon_{33}=0
\end{array}\right.
$$

where $\mathbf{B}_{1}=\frac{2 \psi+\mathbf{K}}{3} ; \mathbf{B}_{2}=\frac{\mathrm{K}-\psi}{3}$

$$
b_{i j}=\left(\frac{\sigma_{i j}}{2 G}\right)^{*}+\delta_{i j}\left[\sigma^{*}\left(K-\frac{1}{2 G}\right)^{*}-\Delta \varphi\right], i, j=1,2,3 .
$$

Let us define the temporary stresses $\sigma_{i j}$ and deformations $\varepsilon_{i j}$ to the end of welding process (before unloading). The full stress $\left(\sigma^{n}{ }_{i j}\right)^{1}$ and complete deformation $\left(\varepsilon^{n}{ }_{i j}\right)^{1}$ will be equal to the temporary stress and temporary deformation, respectively. At the final moment of welding, i.e. in the moment of arc welding, let us solve the elasticity problem 
2.

$$
\begin{gathered}
\left\{\begin{array}{l}
\frac{\partial \sigma_{11}}{\partial \mathrm{x}_{1}}+\frac{\partial \sigma_{12}}{\partial \mathrm{x}_{2}}=0 \\
\frac{\partial \sigma_{21}}{\partial \mathrm{x}_{1}}+\frac{\partial \sigma_{22}}{\partial \mathrm{x}_{2}}=0
\end{array}\right. \\
\frac{\partial^{2} \varepsilon_{11}}{\partial \mathrm{x}_{2}^{2}}+\frac{\partial^{2} \varepsilon_{22}}{\partial \mathrm{x}_{1}^{2}}=2 \frac{\partial^{2} \varepsilon_{12}}{\partial \mathrm{x}_{1} \partial \mathrm{x}_{2}} \\
\left\{\begin{array}{c}
\sigma_{11}\left(M^{\mathrm{I}}\right) \mathrm{n}_{1}+\sigma_{12}\left(M^{\mathrm{I}}\right) \mathrm{n}_{2}=\mathrm{g}_{1}\left(\mathrm{M}^{\mathrm{I}}\right) \\
\sigma_{21}\left(\mathrm{M}^{\mathrm{I}}\right) \mathrm{n}_{1}+\sigma_{22}\left(M^{\mathrm{I}}\right) \mathrm{n}_{2}=\mathrm{g}_{2}\left(\mathrm{M}^{\mathrm{I}}\right)
\end{array}\right.
\end{gathered}
$$

where $\mathrm{M}^{\prime} \in \Gamma, \mathrm{n}_{1}, \mathrm{n}_{2}$ - directional cosines to $\Gamma$;

$$
\left\{\begin{array}{c}
\varepsilon_{11}=\frac{1}{4 \mu(\lambda+\mu)}\left[(\lambda+2 \mu) \sigma_{11}-\lambda \sigma_{22}\right], \\
\varepsilon_{22}=\frac{1}{4 \mu(\lambda+\mu)}\left[-\lambda \sigma_{11}+(\lambda+2 \mu) \sigma_{22}\right], \\
\varepsilon_{12}=\varepsilon_{21}=\frac{1}{2 \mu} \sigma_{12}=\frac{1}{2 \mu} \sigma_{21},
\end{array}\right.
$$

After welding and before complete cooling of the body (before complete unloading), the full stress $\left(\sigma_{\mathrm{ij}}^{\mathrm{n}}\right)^{2}$ equals to the stress value at the moment of full unloading.

The complete deformation is determined by the formula

$$
\left(\varepsilon_{\mathrm{ij}}^{\mathrm{n}}\right)^{2}=\varepsilon_{\mathrm{ij}}^{\mathrm{e}}+\alpha \Delta \mathrm{T},
$$

where $\varepsilon_{\mathrm{ij}}^{\mathrm{e}}-$ elastic deformation, which equals to the value of the fully unloaded state; $\alpha \Delta \mathrm{T}$ - temperature deformation.

3. Let us determine the residual stress and deformation in the beam after welding

$$
\left\{\begin{array}{l}
\varepsilon_{\mathrm{ij}}^{0}=\left(\varepsilon_{\mathrm{ij}}^{\mathrm{n}}\right)^{1}-\left(\varepsilon_{\mathrm{ij}}^{\mathrm{n}}\right)^{2} \\
\sigma_{\mathrm{ij}}^{0}=\left(\sigma_{\mathrm{ij}}^{\mathrm{n}}\right)^{1}-\left(\sigma_{\mathrm{ij}}^{\mathrm{n}}\right)^{2}
\end{array}\right.
$$


In order to check the adequacy and reliability of the proposed method for determination of residual stresses and deformations, the author calculated the specified characteristics of the center sill welded of two Z-like rolled sections of the size $16 \times 130 \times 10.5 \times 183 \times 9 \times 310$, the cross-section of which is shown in Fig.1. 5

The center sill elements are produced of Steel 345-09G2S-14 GOST 5267.0-90. The main characteristics at local temperature effects on steel were taken from the study. The geometrical characteristics of the center sill's sections and the dynamic calculation data. The Z-like rolled sections were joined by automatic welding under a flux layer; the data for calculation under flux material 09G2S were: current force $175 \mathrm{~A}$, electrode diameter $4 \mathrm{~mm}$, and welding speed $4 \mathrm{mph}$. The other joints were made by half-automatic welding in the protective gas environment. The length of a non-standard welded joint and other data for calculation were obtained and presented in Appendix B.

The initial data and basic prerequisites of the set assignment were based on the results of theoretical and experimental research by E.O. Paton, M.O. Okerblom, V.I. Makhnenko, V.A. Riapolov, L.M. Lobanov, V.O. Vinokurov and others.

Fig. 1.5 illustrates deformations (deflection) of the center sill after welding.

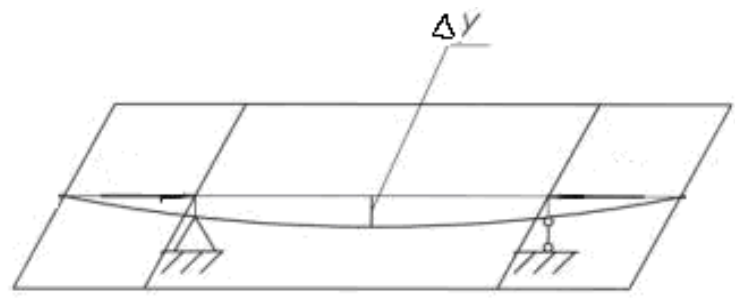

Fig. 1.5. Scheme of deformations in center sill after welding.

Table 1.1 presents the distribution of residual stresses and deformations obtained by the proposed method after welding on a similar center sill. The adequacy and reliability of the proposed method was estimated by comparing the results with those obtained through calculation by the method of fictitious shrinkage force according to V.A. Vinokurov and others (the Bauman Moscow State Technological University, BMSTU) and by V.I. Makhnenko's method based on the shrinkage function. 
Table 1.1

Results of residual deformation calculation after production of center sill of open wagons

\begin{tabular}{|c|c|c|c|}
\hline $\begin{array}{c}\text { Deformation } \\
\text { (deflection), } \mathrm{mm}\end{array}$ & $\begin{array}{l}\text { By method of } \\
\text { fictitious } \\
\text { shrinkage } \\
\text { force }\end{array}$ & $\begin{array}{l}\text { By method } \\
\text { based on } \\
\text { shrinkage } \\
\text { function }\end{array}$ & By proposed method \\
\hline $\begin{array}{l}\text { Deflection }(\Delta Y 1) \\
\text { after welding Z-like } \\
\text { rolled sections }\end{array}$ & 6.5 & 6.7 & 7.1 \\
\hline $\begin{array}{l}\text { Deflection }(\Delta Y 2) \\
\text { after welding top } \\
\text { cord (H-girder № } \\
\text { 19) }\end{array}$ & 3.03 & 3.5 & 3.7 \\
\hline $\begin{array}{l}\text { Main deflection } \\
(\Delta Y) \text { of beam after } \\
\text { welding }\end{array}$ & 9.53 & 10.2 & 10.8 \\
\hline
\end{tabular}

Besides, it should be mentioned that studies [48, 49] present similar results on deflections of the longitudinal axle of the center sill. On the basis of a built distribution of residual plastic shrinkage deformations in the longitudinal section of the center sill the following parameters were calculated: shrinkage force Pyc $=5.408 \cdot 10^{5} \mathrm{~N}$; calculated coordinates of the shrinkage force point and eccentricity $\mathrm{e}=11.485 \mathrm{~cm}$; longitudinal deflection of the center sill axle $\mathrm{f}=1.379 \mathrm{~cm}$.

\subsection{Methods to control welding deformations and stresses}

The high welding temperatures change both physical and mechanical characteristics. And the basic reasons for residual stresses and deformations in welded elements of wagon metal structures are [36]:

- local irregular heating of metal. As know, at heating all metals expand, and at cooling they shrink. Thus, local heating of metal under welding with consequent cooling of a welded joint creates an irregular temperature field. Thus, the welded detail undergoes compressive thermal internal stresses and/or tension stresses. The value of these stresses mainly depends on heating temperature, linear expansion coefficient, and thermal conductivity of the welded metal. Under welding of a rigidly fixed structure 
the value of thermal stresses can increase due to restrictions of its free movement during heating and cooling. At first the heated structure undergoes compression internal stresses due to its expansion, and at consequent cooling - torsion stresses due to its shortening. When the internal stresses reach the yield limit level plastic deformations change the form and dimensions of the welded metal product. After welding the residual stresses can be observed in places of irregular plastic deformations;

- irregular structural transformations in metal. Carbon and alloyed steel structures heated to the critical temperatures can suffer from stresses due to phase transformations with change in the crystal grid type and formation of a phase of great specific volume and another linear expansion coefficient. The greatest stresses can appear under welding of hardening alloyed-steel structures. In such steels the structural transformation runs along with formation of the so-called hardening structures (martencite) of great specific volume, higher hardness, fragility and lower plasticity. Such transformation runs along with a volume growth; the metal adjacent to it undergoes the torsion stresses, and the area of martencite structure stretches. For non-plastic alloys it can lead to crack development;

- casting shrinkage of weld metal. Under cooling and hardening the molten metal of a joint shrinks. It is explained by higher metal density leading to its lower volume. Due to a close link between weld metal and base metal, which keeps the same volume and resists shrinkage, there appear longitudinal and transverse internal stresses which cause the corresponding deformations of welded joints. Longitudinal shrinkage causes deformations in a longitudinal direction relative to the joint axis, and transverse shrinkage generally causes angular deformations.

Therefore structural and technological techniques are used to avoid residual stresses and deformations under welding.

The structural method implies the optimal design of welded assemblies, and includes the following techniques:

- establishing the minimum sections in welded joints (by strength condition) to decrease the volumes where plastic deformations run;

- avoiding excess concentrations and sections of welded joints to decrease in-plane and three-dimensional stresses, particularly, in structures under impact and variable loads;

- placing welded joints symmetrically to the gravity center of a product for the mutual equilibrium of the bending moments appearing;

- prior use of butt joints as they are least rigid and characterized by low concentration of power loads in comparison with angular joints; 
- avoiding pads, gusset plates, etc, which increase in-plane deformations;

- use of additional elements in the form of strengthening ribs to maintain the strength of elements and secure from formation of bulgings in the spatially-developed structures of box-likes sections. The transverse shrinkage can be decreased by placing a strengthening rib so that the same areas of the base metal should be heated in welding;

- adding allowances for contraction to the nominal dimensions of a product, which equals to metal shrinkage to balance deformation; and

- location of welded joints so that they do not hamper mechanization of welding.

The technological method is based on the optimal choice of a thermal mode, layout and welding technology; it includes the following:

- applying an optimal thermal welding mode, in which a heating zone of welded details (an active zone's width) is minimum;

- increasing the current density of welding for even heating of the metal through the depth. It results in a deep root penetration and, thus, in a decrease of gaps in butt joints, which decreases transverse shrinkage;

- avoiding application of tick welds to fix assemblies and details which form rigid fixation;

- applying wedge, centering and other assembly tools to ensure movable condition of fixed details. Besides, assembly tools must provide free movement of details toward longitudinal shrinkage and prevent their turns, thus avoiding angular deformations;

- ensuring preliminary mutual layout of details considering possible deformations and deflections, which can be eliminated after welding;

- applying the joint sequence pattern at which internal stresses balance relative to the center of gravity of a welded structure without considerable superheating and shrinkage of metal. The joint sequence pattern must ensure the balance between stresses and deformations. Deformation of a joint must be compensated by deformation of a following joint;

- ensuring free movement of welded elements. It especially refers to butt joints which suffer from large transverse shrinkage. Therefore, butt joints should be welded before corned joints. Thus, while welding I-like beams, walls and faces should be welded first, before belts which are welded with fillet joints;

- hammering during welding to decrease deformations. The hammering strengthens the joint by flattening a cooling weld layer, and thus, decreasing 
the joint shrinkage. It is not recommended to hammer the last outer layer, as it may lead to development of cracks on the joint surface.

Continuous studies into welding stresses and deformations have formed a system of their calculation and elimination, which is used at wagon building enterprises. Thus, the basic techniques to avoid welding deformations are: optimal design engineering (basic principles of which are presented in normative documents for design and production of different metal structures, including freight wagons); fixation of products (widely used in wagon production); creation of deformations opposite to welding ones (used in production of axial and beam elements of wagons); mechanical impact from plastic deformations in the joint zone, which leads to fewer residual deformations; and regulation of a thermal impact by removing heat from the welded product [50].

Issues of control over welding deformations and stresses have attracted specialists all over the world since welding has been used to get integral joints. As early as in 1892 N.G. Slavianov wrote about a danger of harmful stresses in metals under welding processes. However, only in 1930s, with wide application of welding in production, this problem was thoroughly studied and presented in theoretical and experimental research.

And here we should distinguish the control aimed at fewer residual stresses, which may cause problems with the carrying capacity of welded structures (brittle strength, fatigue at changeable stresses, resistance to aggressive conditions, etc.), and the control to prevent (decrease) welding deformations, which change the design forms and dimensions of a structure, worsens the marketable condition of a product, and sometimes even the performance.

During recent years the specialists worked out a number of approaches to regulate welding stresses and deformations. Nominally, these approaches can be divided into three groups.

The first group includes a set of methods dealing with design of a welded structure (structural forms, thicknesses, location of welded joints, etc.). Structural aspects of welded products in terms of residual stresses and deformations are considered in studies [51-53]. So, study [51] presents the results of numerical research with the method of thermal plasticity and finite element method aimed at minimization of deformations of welded panels by optimizing such factors as fillet joint location, distance between welded ribs of rigidity, rib rigidity configuration, and welding sequence pattern. With an approximate calculation method used in [52] the authors study an effect of a gap between the rib and the finishing on general torsional deformations in 
welded panels of a specified initial curvature; this gap can be eliminated with a force action during laying-out for welding. It is shown that such a divergence in curvature after blank production can considerably affect residual deformations in a welded panel. Study [53] demonstrates an efficiency of fully-welded carrying elements of freight wagon bogies, which are of higher stability and more interoperable among those produced at present.

The second group includes a set of methods used during welding (welding mode [54], sequence of weld passes, supporting heating or cooling, power loading, etc.).

One of the effective technological methods to decrease residual welding stresses in welded plane thin-sheet structures is the preliminary tension [55]. Recently this method has developed in the form of different techniques of preliminary tension, used during welding with local heating $[56,57]$ or cooling $[58]$ at both sides from the welded joint.

The supporting induction heating of a wall for compensation of residual longitudinal deflections of a beam [59] is widely used in production of Tshaped beams. Study [60] suggests computation the optimal heating parameters for T-beams.

The third group deals with post-welding treatment of welded structures and aimed at a decrease in residual welding stresses (general or local thermal treatment, appropriate mechanical treatment by rolling, with impact pneumatic tools, impact ultra-sound treatment, etc.).

The post-welding general and the local thermal treatment are widely used to decrease the residual stresses. Modelling of these technological operations for optimization of parameters is considered in many studies [61].

Recently, a lot of engineers work at the numerical modelling of impact ultra-sound treatment of welded joints. Study [62] presents a residual stress distribution in a welded joint after welding and after application of an impact ultra-sound treatment with the finite element method in commercial ANSYS software. It was shown that right parameters of this treatment (treatment place, frequency and amplitude of injections) can prolong the life cycle of a welded joint, and may compensate angular deformations.

Here it should be mentioned that thermal straightening methods are very popular for welded structures at the current state of production [63-66]. But the thermal straightening requires highly qualified manual labour, and its efficiency greatly depends on a straightener's experience and qualification, which considerably complicates mechanization (automation) of such operations. 


\subsection{Classification of straightening methods for wagon structures and advantages of thermal straightening}

Mechanical properties of metals are determined by their capacity to carry external loads, i.e. be resistant to deformations and damage. They suffer from two different types of deformations, i.e. elastic and plastic, which differ in external manifestation and internal mechanisms. It is clear that the properties which define the elastic and plastic condition of metals are described by different characteristics.

Elastic deformations are the result of change in inter-atomic distances; they are reversible and do not change the structure and properties of metal. The reversibility means that after taking off the load the body returns its previous form and dimensions, without residual deformations.

Plastic deformations are the result of formation and movement of dislocations, which change the structure and properties of metal. After taking off the load the deformations maintain, thus, plastic deformations are of irreversible nature.

At present there are a lot of straightening methods used for restoration of details' geometrical forms at the final welding stage $[65,66]$. Among them are general or local thermal treatment; local heating which implies concentrated heating of small deformed areas of the structure; thermal treatment in clamping mechanisms; impulse and vibration loading on welded joints of metal structures or their assemblies; mechanical treatment by rolling; mechanical treatment by impact pneumatic tools; rolling of welded joints with rolls; pivoting and straightening based on formation of plastic deformations, opposite to welding ones; cold and hot deformation; impact ultra-sound treatment; and active loading. At the same time all these numerous methods can be reduced to two groups, namely methods of deformation by external forces (cold straightening) and methods of deformation by temperature (thermal straightening).

The physical nature of the cold straightening is deformation of the metal structure by plastic bending at an ambient temperature, thus elimination of a distortion and formation of a rectangular form. Due to deformation the product gets a flux which increases the yield limit of metal. The range of plasticity of such structures considerably narrows. Due to riveting the mechanical properties become heterogeneous, it decreases the static and fatigue structural strength. 
At the same time the physical nature of the cold straightening can be considered a bit differently. A bended structural element presents a beam loaded with straightening forces. If the value of this force is sufficient to form plastic deformations in the structural element, it can elongate the short fibers of the element and reduce its long fibers under action of this force. These processes can run together or separately according to peculiarities of the straightening type used. Thus, the straightener has to identify the areas where to apply a straightening force, its value and duration on the structural element according to nature and value of deformations. The cold straightening is conducted with presses, jacks, rollers or manually with blacksmith tools. Plastic deformations of details in cold condition requires considerable external forces, therefore, this procedure can renew a detail of non-ferrous metals and their alloys, as well as steel details of up to $0.3 \%$ carbon which were not thermally treated before. At present the cold straightening of technologically-deformed wagon metal structures is the simplest and most popular procedure, however it rarely guarantees a stable form of treated details, and the deformation eliminated can appear again.

The reason for an unstable form of the details treated by cold straightening can be explained by the heterogenic nature of residual stresses due to irregular deformations in the metal. Besides, the properties of the base metal deteriorate, i.e. the impact viscosity decreases, and due to fluxes as a result of deformation the yield limit of metal increases. Besides, riveting leads to heterogeneity of the mechanical properties, which worsens the static and fatigue structural strength. At the same time as far as devices for cold straightening are huge stationary equipment, their application is usually restricted by structural and geometric characteristics of the presses.

Among advantages of the cold straightening is high efficiency of straightening machines. However, equipment for cold straightening used in production and maintenance of freight wagons has big dimensions and mass; thus, it is rather huge stationary equipment. Besides they work periodically with long idle time, thus, production areas are used ineffectively, and the specific production volume decreases. Generally, the cold straightening is restricted by structural and geometrical characteristics of presses (by height, frame's width, absence of ribs of rigidity etc.). The properties of the base metal deteriorate after cold plastic deformation: impact viscosity decreases, yield point increases.

A traditional method of form stabilization for technologically-deformed wagon metal structures is the cold straightening, but one of the most optimal is the thermal straightening in terms of lower residual deformation 
stabilization of the structure; the procedure of thermal straightening eliminates deformations by creating plastic deformations emerging at local high-temperature heating of metal with a gas-oxygen flame or electric arc.

When the product is heated to a temperature of $0.8-0.9$ out of the melting temperature, plastic deformation forces decrease by 12-15 times without considerable change in physical and mechanical properties of metal. In comparison with the cold straightening procedure, thermal straightening does not require special equipment, and is conducted due to plastic deformations at local high-temperature heating of metal with a gas burner. However, the thermal straightening still remains a labour-consuming procedure, as it is conducted manually and requires high qualification from a straightener, who must take into account many parameters which in combination influence the result of straightening [67].

One of the most economically attractive methods of form stabilization for frame elements of open wagons in production is thermal straightening; it implies a local heating of appropriate zones, it results in straightening of deflections appeared in welding [4, 68, 69]. The basic advantage of this type of straightening is its universal nature, as it can be used for any welded metal structure of complex configuration and dimensions (e.g. the center sill of an open wagon). The thermal straightening consists of heating appropriate areas of a welded structure with their subsequent cooling. At the temperature 750$850{ }^{\circ} \mathrm{C}$ a deformed heated area expands, but the cold metal nearby restricts it, which results in compressive plastic deformations. After cooling the linear sizes of the heated area decrease, thus reducing or completely eliminating the deformations.

Besides, it should be mentioned that the thermal straightening with local heating can be applied practically for any straightening of a vertical deflection in elements of the carrying systems of wagons and their bodies, while the cold straightening cannot be used in these particular cases. Thus, the thermal straightening has more potential, than the cold straightening.

The thermal straightening of welded elements of an open wagon can be referred to non-productive costs. The value of residual plastic deformations at thermal straightening depends on the maximum value and distribution of heating temperature, power of heating sources, number and location of heated areas, residual stresses and structural rigidity, rigidity of external fixation, etc. Thus, the efficiency of the thermal straightening depends on a great number of parameters, which is the main problem for automation of such a technological operation. One of the solutions to the problem is a choice of the 
optimal parameters of heating, number and location of heating areas, on the basis of the mathematical modelling of the thermal straightening.

The existing calculation methods for temperature stresses and deformations under heating can be divided into two groups. The first group includes methods which determine analytical average deformations (by the cross-section of an element) according to the welded joint position [70]. But they cannot consider irregularity in the temperature distribution by section under formation of the thermo-stressed state. Therefore, they cannot be used for the modelling of thermal straightening processes. The second group includes methods for calculation of the thermo-stressed state and deformations at a different temperature distribution by cross-sections of the element, and considers change in the thermal and mechanical characteristics (yield limit, elasticity modulus, linear expansion coefficient, etc) according to the temperature and the initial stress state. The foundation of these methods is the principles of the theory of material strength and the modelling of the thermo-stressed state at high-temperature heating [71].

By considering the foundations of the theory of thermal stresses and deformations, one should mention that thermal deformations emerge at heating only under factors influencing free thermal expansion of a body. Generally, these factors are regarded as structural characteristics or irregular heating. The thermal stresses in bodies are the result of thermal deformations. When temperature is low and material deforms smoothly, the thermal stresses are proportional to elasticity modulus E, linear expansion coefficient $\alpha$, change in temperature $\Delta T$ according to Hooke's law.

$$
\sigma=\varepsilon \cdot E=\alpha \cdot \Delta T \cdot E .
$$

Practically, emergence of plastic deformations in material is of great interest. As a rule, it runs under high temperature gradients and comparatively high temperatures. A growth in temperatures changes the mechanical characteristics of material and the stress/deformation diagram. Thus, with an irregular temperature distribution the properties of material become heterogeneous. At a high temperature the creep effect intensifies: stresses and deformations change with time. In most cases, particularly under thermal straightening, an analysis of stresses is greatly complicated by unsteady thermal fields.

The above-mentioned review of the straightening methods forms the classification of straightening methods for carrying metal structures of freight wagons and their elements presented in Fig.1.6 as a diagram [67]. 


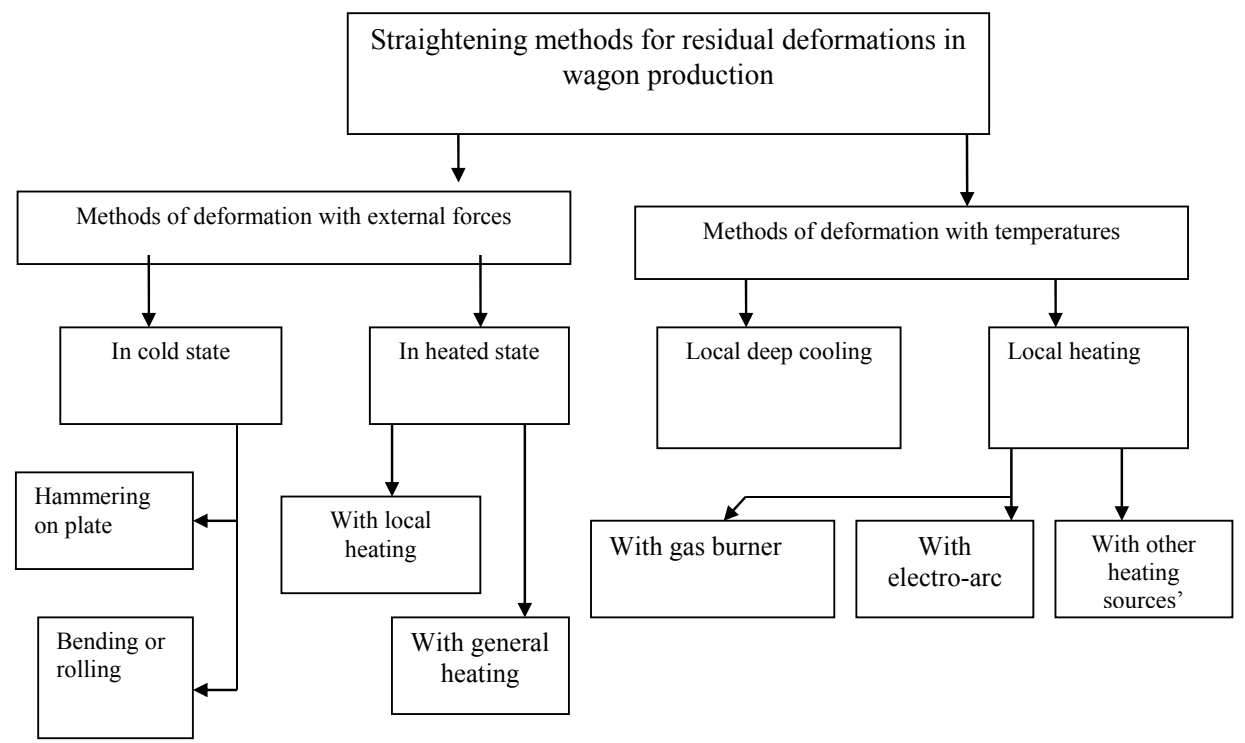

Fig. 1.6. Classification of straightening methods used in wagon production

In spite of great variety of elements to be straightened and production conditions at wagon building plants there are only three factors to be taken into account when choosing the appropriate equipment.

1. A possibility to strengthen a certain element with a certain method under certain conditions of the enterprise. It is determined by versatility of straightening equipment (e.g., rollers and presses for certain types of elements); suitability of the workshop (e.g., additional transport facilities for long beams); technical conditions; other specific conditions (e.g., energy consumption restrictions).

2. Straightening process speed. It is determined by the speed of three operations: straightening, preparation and final operations connected with straightening equipment (additional operations of the first type), and preparation and final operations connected with transport and crane equipment (additional operations of the second type). The thermal straightening includes only additional operations of the first type, and the cold straightening includes operations of the first and second types.

3. Production cost. Basically, it is determined by four components: cost of equipment; cost of equipped workshop; cost of additional straightening equipment; and energy consumption. Energy consumption costs for thermal 
and cold straightening can be considered as equal. Thus, in terms of the production cost the thermal straightening is more economical.

Because of a great number of parameters for estimation of the efficiency of cold and thermal straightening, it was decided to estimate a graphical ratio of an effect from cold and thermal straightening on each factor, respectively. For visual clarity these straightening types got contrast colours: black for cold straightening and white for thermal straightening. And for visual clarity it was also decided to combine tables and diagrams presenting the dependencies obtained. The objective of the study [67] is determination of dependencies with generalized numerical values for different characteristics. The areas of application and prospects of development of both straightening types were also regarded. All characteristics under study for cold and thermal straightening, and groups of structural, organizational and operational parameters are given in Tables 1.2 - 1.4. Table 1.5 arranges the results of the previous three tables presented as graphical ratios of the cold and thermal straightening by preferences.

Table 1.2

Comparison of cold and thermal straightening by operational parameters

\begin{tabular}{|c|c|cc|}
\hline Number & Operational parameter & $\begin{array}{c}\text { Efficiency ratio for cold }(\mathrm{C}) \text { and thermal } \\
(\mathrm{T}) \text { straightening }\end{array}$ \\
\hline 1 & $\begin{array}{c}\text { Availability of straightening } \\
\text { equipment (only) }\end{array}$ & $\mathrm{C}-100 \%$ & $\mathrm{~T}-0 \%$ \\
\hline 2 & $\begin{array}{c}\text { Availability of straightening } \\
\text { equipment and machine }\end{array}$ & $\mathrm{C}-50 \%$ & $\mathrm{~T}-50 \%$ \\
\hline 3 & Availability of machine only & $\mathrm{C}-0 \%$ & $\mathrm{~T}-100 \%$ \\
\hline 4 & Workshop area restrictions & $\mathrm{C}-0 \%$ & $\mathrm{~T}-100 \%$ \\
\hline 5 & Insufficiency of gases & $\mathrm{C}-100 \%$ & $\mathrm{~T}-0 \%$ \\
\hline 6 & Insufficiency of electricity & $\mathrm{C}-0 \%$ & $\mathrm{~T}-100 \%$ \\
\hline 7 & Insufficiency of gas and electricity & $\mathrm{C}-50 \%$ & $\mathrm{~T}-50 \%$ \\
\hline 8 & Workload of crane and other & $\mathrm{C}-0 \%$ & $\mathrm{~T}-100 \%$ \\
\hline 9 & transport means & $\mathrm{C}-65 \%$ & $\mathrm{~T}-35 \%$ \\
\hline 10 & With straightening efficiency & $\mathrm{C}-0 \%$ & $\mathrm{~T}-100 \%$ \\
\hline
\end{tabular}


Table 1.3

Comparison of cold and thermal straightening by structural parameters

\begin{tabular}{|c|c|cc|}
\hline Number & Structural parameter & $\begin{array}{c}\text { Efficiency ratio for cold (C ) and thermal } \\
(\mathrm{T}) \text { straightening }\end{array}$ \\
\hline 11 & Wagon body beams: & $\mathrm{C}-90 \%$ & $\mathrm{~T}-10 \%$ \\
\hline 12 & - of short length & $\mathrm{C}-50 \%$ & $\mathrm{~T}-50 \%$ \\
\hline 13 & - of average length & $\mathrm{C}-25 \%$ & $\mathrm{~T}-75 \%$ \\
\hline 14 & - of long length & $\mathrm{C}-0 \%$ & $\mathrm{~T}-100 \%$ \\
\hline 15 & Bith welded ribs of rigidity & & \\
\hline & & $\mathrm{C}-0 \%$ & $\mathrm{~T}-100 \%$ \\
\hline
\end{tabular}

Table 1.4

Comparison of cold and thermal straightening by organizational parameters

\begin{tabular}{|c|c|c|}
\hline Number & Organizational parameter & $\begin{array}{l}\text { Efficiency ratio for cold }(\mathrm{C} \quad \text { ) and thermal } \\
\qquad(\mathrm{T} \quad) \text { straightening }\end{array}$ \\
\hline 16 & Automatic transfer lines & $\mathrm{C}-100 \% \quad \mathrm{~T}-0 \%$ \\
\hline 17 & Conveyor production line & $\mathrm{C}-50 \% \quad \mathrm{~T}-50 \%$ \\
\hline 18 & Single production & $\mathrm{C}-15 \% \quad \mathrm{~T}-85 \%$ \\
\hline 19 & $\begin{array}{l}\text { Combination of laying-out, welding } \\
\text { and straightening }\end{array}$ & $\mathrm{C}-0 \% \quad \mathrm{~T}-100 \%$ \\
\hline 20 & $\begin{array}{l}\text { Combination of straightening for } \\
\text { bulging deformation and deflection }\end{array}$ & $\mathrm{C}-30 \%$ \\
\hline 21 & Cost benefit & $C-50 \%$ \\
\hline 22 & $\begin{array}{l}\text { Method of deflection straightening } \\
\text { for other technological operations }\end{array}$ & $\mathrm{T}-100 \%$ \\
\hline
\end{tabular}


Table 1.5

Rational application ratio for cold and thermal straightening

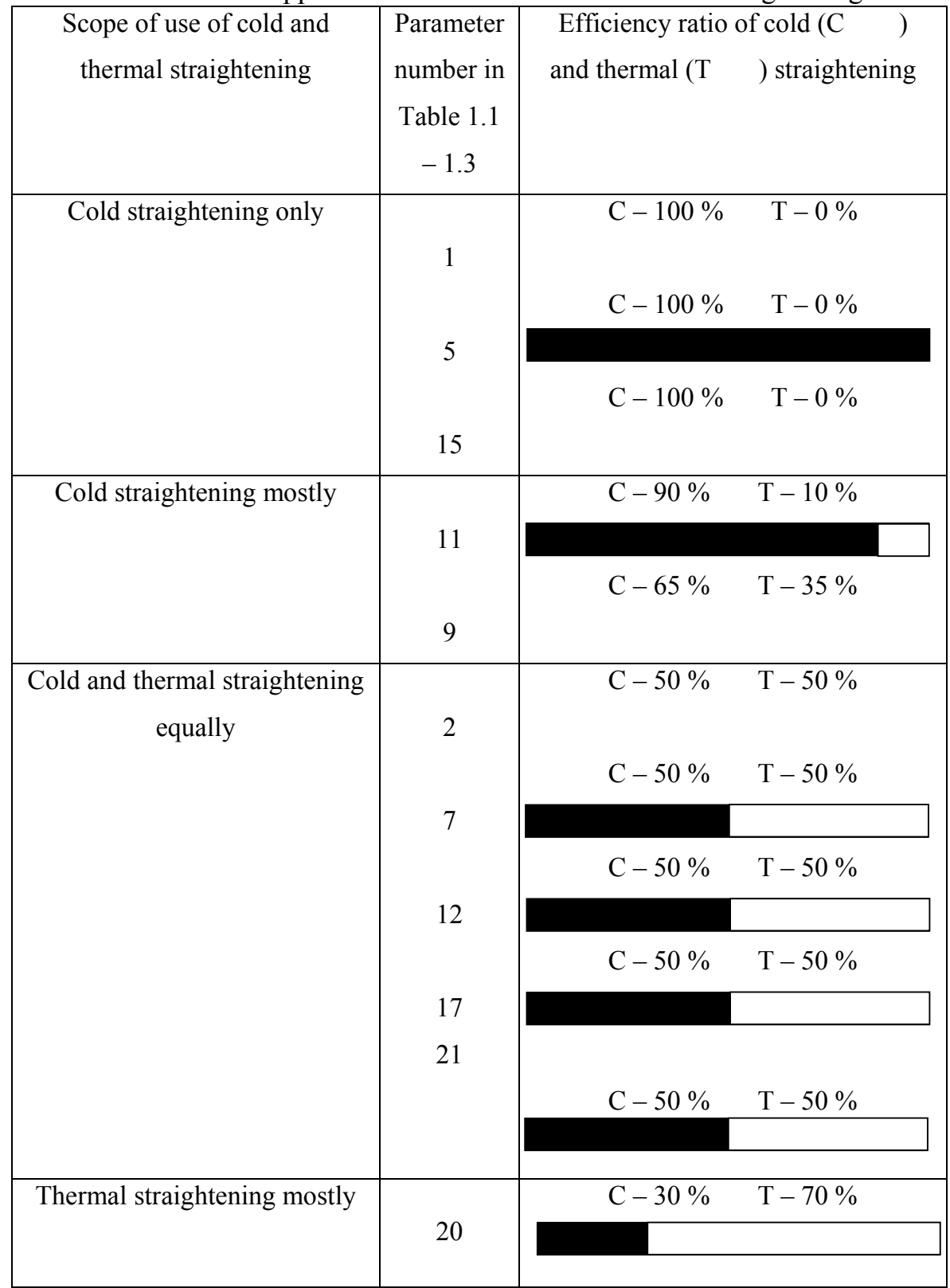




\begin{tabular}{|c|c|c|c|}
\hline \multirow{4}{*}{$\begin{array}{l}\text { Scope of use of cold and } \\
\text { thermal straightening }\end{array}$} & \multirow{4}{*}{$\begin{array}{l}\text { Parameter } \\
\text { number in } \\
\text { Table } 1.1 \\
-1.3\end{array}$} & \multicolumn{2}{|c|}{ Efficiency ratio of cold (C) } \\
\hline & & and thermal $(\mathrm{T}$ & ) straightening \\
\hline & & & \\
\hline & & & \\
\hline & 13 & $\mathrm{C}-25 \%$ & $\mathrm{~T}-75 \%$ \\
\hline & 18 & $C-15 \%$ & $\mathrm{~T}-85 \%$ \\
\hline \multirow[t]{16}{*}{ Thermal straightening only } & & $\mathrm{C}-0 \%$ & $\mathrm{~T}-100 \%$ \\
\hline & & $\mathrm{C}-0 \%$ & $T-100 \%$ \\
\hline & \multirow[t]{2}{*}{4} & & \\
\hline & & $\mathrm{C}-0 \%$ & $T-100 \%$ \\
\hline & \multirow[t]{2}{*}{6} & & \\
\hline & & $\mathrm{C}-0 \%$ & $T-100 \%$ \\
\hline & \multirow[t]{2}{*}{8} & & \\
\hline & & $\mathrm{C}-0 \%$ & $\mathrm{~T}-100 \%$ \\
\hline & \multirow[t]{2}{*}{10} & & \\
\hline & & $\mathrm{C}-0 \%$ & $T-100 \%$ \\
\hline & \multirow{2}{*}{14} & & \\
\hline & & $\mathrm{C}-0 \%$ & $\mathrm{~T}-100 \%$ \\
\hline & 15 & & \\
\hline & \multirow{2}{*}{19} & $2-010$ & $1-10070$ \\
\hline & & $\mathrm{C}-0 \%$ & $\mathrm{~T}-100 \%$ \\
\hline & 22 & & \\
\hline
\end{tabular}

It should be mentioned that dependencies presented in Table 1.5 are qualitative estimation of the use of both straightening types, as they do not consider the value of each characteristics, which can be expressed by different width of the bar representing a certain characteristic; but it could complicate presentation and understanding of the dependencies, therefore this approach was rejected to return to it in future. The analysis of Table 1.5 enables to estimate the prospects of application of the thermal straightening; it is an endevour to generalize an expert analysis of the qualitative effective application ratio for cold and thermal straightening.

If we put on the horizontal axis the general volume of straightening in elements of the body for a given range in percent, and on the vertical axis - 
the efficiency of cold and thermal straightening (in percent), and if we divide the general volume into separate groups of elements, we will obtain the general comparison of efficiencies for two straightening types (Fig. 1.7).

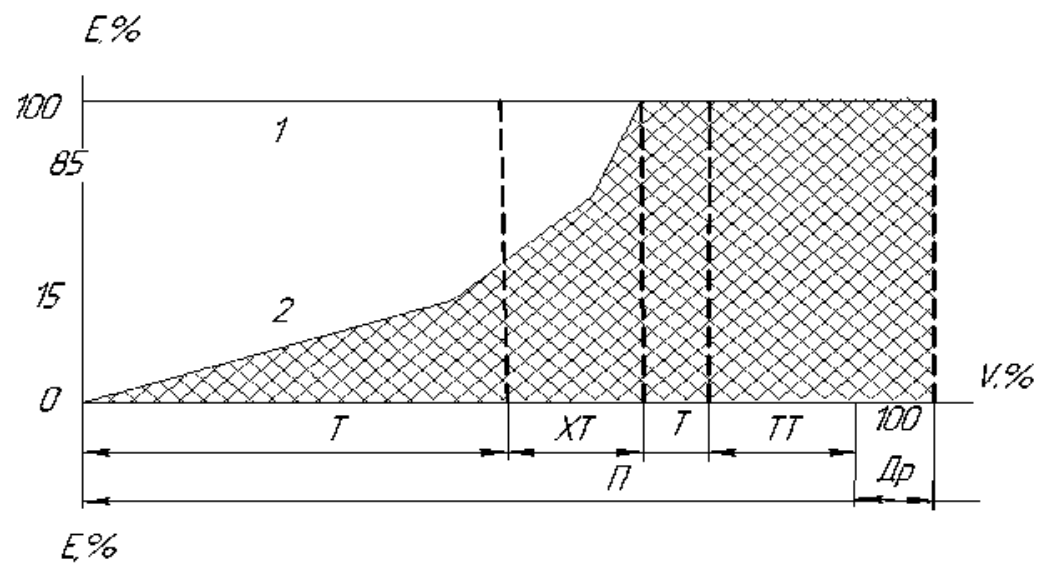

Fig. 1. 7. Comparison of efficiencies of cold and thermal straightening 1, 2 - Relative efficiency for cold and thermal straightening, respectively;

$\mathrm{S}$ - straightening zone which includes

$\mathrm{C}$ - cold straightening is preferable;

$\mathrm{CT}$ - efficiencies of cold and thermal straightening are equal;

$\mathrm{T}$ - thermal straightening is preferable;

TT - thermal straightening is an only opportunity;

Ors - other thermal straightening applications.

There exist four groups of elements which are straightened at wagon building plants:

group one $(\mathrm{C})$ - cold straightening is more efficient. It is true for great number of similar elements. The experience testifies that straightening on rollers is applied even if elements need to be transported from another workshop;

group two $(\mathrm{CT})$ - the efficiencies are equal for both methods. It refers to small batches, when preparation operations for cold straightening require long time (waiting for a crane, transportation by bogies, etc.);

group three $(\mathrm{T})$ - thermal straightening is more efficient. It refers to single products, production in overloaded workshops, when installation of equipment for cold straightening is not reasonable; and 
group four (TT) - thermal straightening is an only opportunity (compound belts, e.g. I-like ones, when overall sizes exceed the capacity of equipment for cold straightening, when cold straightening is forbidden due to metal properties, etc.).

The efficiency of thermal straightening, apart from mentioned four groups, refers to the group of elements treated similarly, namely, scimitarshape straightening, creation of curved structures, etc. It is group five and it is marked in Fig. 1.7 as Ors.

Fig. 1.8 presents a principle diagram of emergence and straightening of post-welding deformations in the conditional beam of a freight wagon with thermal straightening.

1. Початковнй (до зварювання) стан умовної ба.лкн.

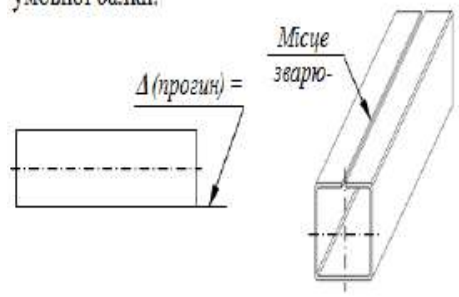

2. Проведення зварювальних робіт.

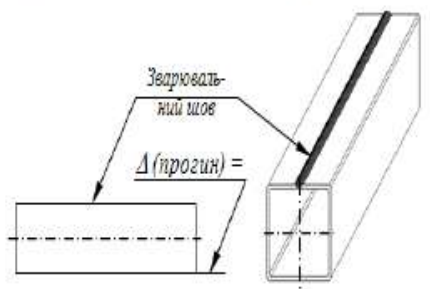

3. Після зварюватьний деформований стан умовноі балки
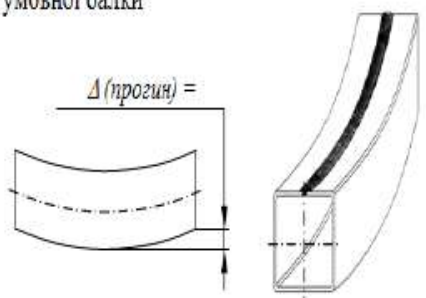

4. Термічннй вптнв газовпм різаком на деформовану балку.

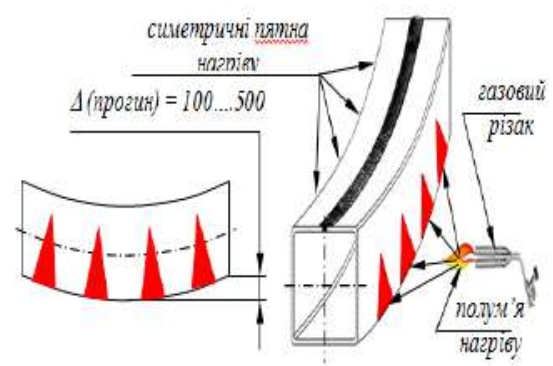

5. Кінцевнй стан (після охолодження) умовної балкн 3 виправленимн після зварювальнимн деформаціями методом термічної правка

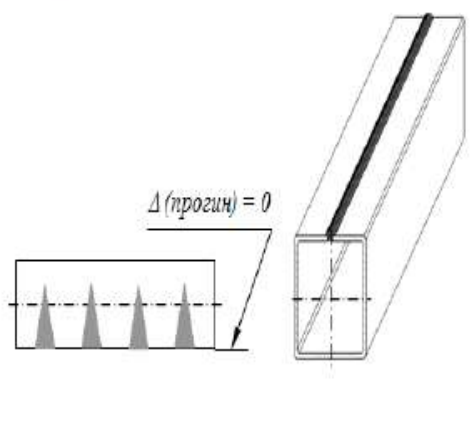

Fig. 1.8. Principle diagram of emergence and straightening of post-welding deformations in conditional beam of freight wagon with thermal straightening 
On the basis of the analysis presented in Tables 1.2-1.5 the following basic advantages of thermal straightening were distinguished:

1) universal nature (straightening of metal structures of complex configuration and large overall sizes);

2) no need for huge stationary equipment (gas cutter or welding apparatus is sufficient);

3) no considerable deterioration of the base metal properties;

4) simplicity of the technological process, ease of use, flexibility, sufficient accuracy and cost-effectiveness.

\section{Conclusions to Chapter 1}

1. It was mentioned that the basic technological process in production of freight wagon elements is welding. The study deals with advantages and disadvantages of welding. The reasons for residual stresses and deformations in wagon metal structures were analyzed. It was mentioned that residual deformations in operation result in lower strength, decreased resistance to corrosion and poor accuracy of a welded structure.

2. Methods for determination of welding stresses and deformations in the carrying structure of freight wagons were considered. The diagrams for measuring residual deformations in welded structures, and deformation diagrams under welding are also presented. The results of the analysis of possible deformations in structural components of freight wagons proved that the basic reasons for them are violation of requirements for operation and technological process conditions. Particularly, it is revealed that over $80 \%$ of deformations are the result of violation of the technology of welding works in production. So, violation of requirements in production of the center sill for universal open wagons leads to a deflection of about $120 \mathrm{~mm}$, which is absolutely inadmissible. And a breach of requirements for the technological process welding in the top cord leads to a deflection of about $500 \mathrm{~mm}$, which is also inadmissible.

3. The research methods for temperature fields and appropriate deformations and stresses were analyzed. It was mentioned that one of the most popular methods to solve engineering problems of thermal elasticity is the finite element method, which is universal and produces quite accurate results.

4. The reasons for residual stresses and deformations were considered. It is mentioned that emergence of residual stresses and deformation under welding can be avoided with application of the structural and technological 
method. The approaches presented deal with control of welding stresses and deformations. Their analysis enabled to choose a way of the post-welding general and local thermal treatment, which is aimed at considerable decrease of residual stresses.

5. The classification of straightening methods for wagon structures fully encompasses and structures all the existing types. In terms of economical characteristics, the thermal straightening method has special advantages among the straightening methods for wagon structures. The study considers the physical nature of cold straightening, underlying its advantages and disadvantages. It presents the results of comparison of cold and thermal straightening for wagon structure elements by operational, structural and organizational parameters, and also the rational application ratio.

The following Chapters of the study are devoted to a search for ways to speed up thermal straightening by optimizing heating zones. 


\section{CHAPTER 2 \\ HIGHER EFFICIENCY OF THERMAL STRAIGHTENING \\ WITH GENERALIZED UNIVERSAL MATHEMATICAL NOTATION OF THERMAL STRAIGHTENING FOR WAGON METAL STRUCTURES}

\subsection{Physical nature and peculiarities of use of thermal straightening for wagon metal structures}

Last years have seen a wide spread of thermal straightening in production of welded structures. And thermal straightening with local heating is of primary importance for production of pilot engineering structures, when proven technological techniques cannot be used for elimination of welding deformations.

The physics of straightening processes with local heating can be studied by heating a small area of a fixed low-carbon steel rod. Let us uniformly heat a rod fixed at both ends (Fig. 2.1, a) on the whole section at the area $A A^{\prime} B B^{\prime}$. The material of the rod is in different physical states: cold areas, which do not change their mechanical properties, and heated area $A A^{\prime} B B^{\prime}$, which decreases the strength and increases the plasticity with an increase of temperature. The heated volume $A A^{\prime} B B^{\prime}$ is the weakest link in the power circuit, because it can take a plastic flow at lower stresses than the other (cold) areas of the metal. Let us describe the processes in the rod with a diagram (Fig. 2.1, b) in the coordinates $\sigma-T$ (stress/temperature). The diagram was obtained by the following way. The yield boundary/temperature curves were built in the coordinates $\sigma-T$ under heating and cooling. As known, the yield boundary decreases with an increase in temperature of the sample. The straight lines show changes in stresses in the sample under change of the heating temperature. While heating to the temperature $T_{A}$ there emerge and develop compression stresses along the strength line $O A$. These stresses reach the yield boundary in the point $A$ at the temperature $T_{A}$ $[72,73]$. 

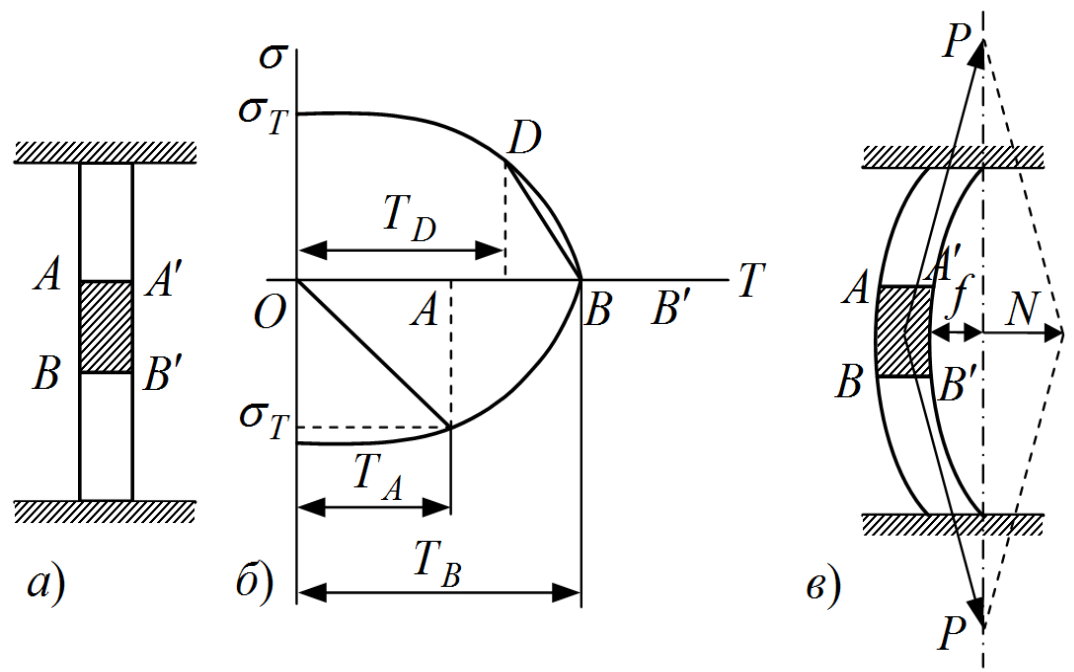

Fig. 2. 1. Thermal straightening physics:

a) fixed rod; b) diagram; c) straightening of rod with local heating

The temperature $T_{A}$ is defined by the formula

$$
T_{A}=\frac{\sigma_{T}}{\alpha \cdot E}
$$

where $\sigma_{T}$ - the yield boundary;

$\alpha$ - linear expansion coefficient;

$E$ - elasticity modulus of the first type.

It should be mentioned that in practice the real temperature is much higher, than that used in formula (2.1), because the rod is not rigidly fixed.

If we take into account that there is no area of temperature gap between cold and heated parts of the rod (as if they are divided with heat impenetrable borders), in heating the volume $A A^{\prime} B B^{\prime}$ elongates and creates the pressure growing to the yield boundary on the adjacent parts of the rod. Under the compression stress in the rod the yield boundary also increases. At heating over $T_{A}$ the stress in the heated volume will decrease by the yield change curve according to temperature. At the temperature $600^{\circ} \mathrm{C}$ they will be equal to zero, as far as at this temperature metal is in the plastic state. The fibers of the volume $A A^{\prime} B B^{\prime}$ under further heating expand by the dependency 
$\Delta l=\alpha \cdot T \cdot l$, however, in terms of braking from cold areas the fibers compress plastically.

At a further heating of the rod above the temperature $600^{\circ} \mathrm{C}$, the fibers do not expand due to barriers - cold volumes of metal. Thus, plastic deformation, i.e. shortening of the volume $A A^{\prime} B B^{\prime}$ will continue. The diagram (Fig. 2.1, b) presents the process as a section of the straight line $B B^{\prime}$, which coincides with the axis of abscissa. When heating stops in the point $B^{\prime}$, the volume $A A^{\prime} B B^{\prime}$ will cool down to $T_{B}$ and shrink while suffering from plastic deformations. In the point $B$ the plastic state turns into the elastic one. And the volume $A A^{\prime} B B^{\prime}$, by shrinking at a further cooling, tends to tear itself off the rest of the metal of the rod, but under the opposite force it begins to stretch, first to the point $D$ elastically along the line $B D$, and then - elastic-plastically, as the pressure reaches the yield boundary. As far as plastic deformation at the temperature lower than $600^{\circ} \mathrm{C}$ emerges only under the stresses equal to the yield boundary, the plastic stretching of the volume $A A^{\prime} B B^{\prime}$ will also undergo under the stresses equal to the yield boundary [72].

These stresses will be in effect when the rod reaches the initial length. Thus, the heating of the volume $A A^{\prime} B B^{\prime}$ to the plastic state leads, at first, to plastic deformation and shortening of fibers along the area heated, then, after cooling it results in plastic deformation and stretching of fibers in the whole rod by compression stresses equal to the yield boundary. These physical processes are in the basis of the straightening process with local heating. Let us demonstrate it by an example of a bent rod of the deflection $f$, rigidly fixed in supports (Fig. 2.1, c).

The heating of the volume $A A^{\prime} B B^{\prime}$ to the temperature $600^{\circ} \mathrm{C}$ leads to plastic deformation of shrinkage of the fiber length, and emergence of the tension stresses $P$ along the rod's axle under cooling. Then these forces cause emergence of the force $N$, which strengthens the rod and, consequently, decreases the deflection. Therefore, the strengthening of the bent rod requires determination of the length of the volume $A A^{\prime} B B^{\prime}$ being heated; this length should ensure its complete strengthening thanks to the physical processes under heating and cooling. Three types of heating are used for straightening: heating symmetrical to the detail's axle, which does not cause the bending moment, it is used for straightening bulges and for thin sheets; heating nonsymmetrical to the detail's axle, which, due to residual compressive plastic deformation, causes the moment, which, by bending the deformed detail, strengthens it; heating independent of the axle of symmetry 
of the detail and, due to compressive plastic deformation, shortens elongated fibers of the product and, consequently, straightens the structure.

The metal structure straightening is a thermal treatment which implies processes of a thermal impact under certain modes in order to change the structure and properties of an alloy. Such factors as heating time (speed), heating temperature, curing time (duration), cooling time (speed) influence the thermal treatment. Thus, the basic thermal treatment factors are temperature and time. Therefore, the thermal treatment process is demonstrated as a diagram in the temperature/time coordinates (Fig. 2.2 and Fig. 2.3); the thermal treatments which consists only of one operation is called simple (see Fig. 2.2), and if it consists of several operations, it is called complex (see Fig. 2.3).

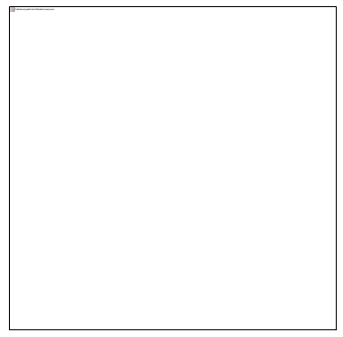

Fig. 2.2.Diagram of simple thermal treatment

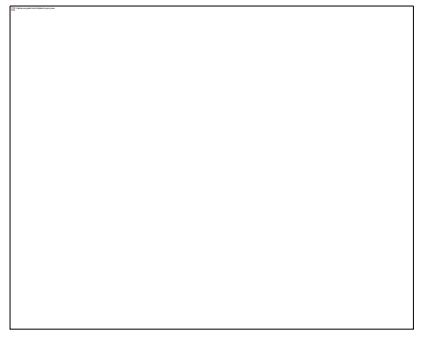

Fig. 2.3.Diagram of complex thermal treatment

\subsection{Mathematical modelling of thermal straightening for wagon metal structures by optimality criterion}

Nowadays the most important condition to improve the welding production is not only development of the theoretical basics of welding with application of innovations from different branches of fundamental and applied sciences, but also creation of highly efficient methods and techniques for modelling and simulation of welding processes. The mathematical methods and mathematic modelling of welding processes applied have been turned into a powerful instrument for research and cognition of processes in complex technological systems, which allow the specialists to obtain a formalized description of their basic dependencies and control them efficiently. The mathematical modelling can optimize conditions of the welding process, avoid inadmissible defects in welded joints of structures, 
and, simultaneously, increase the efficiency of welding operations. Therefore, the issue of higher labour efficiency and lower production cost has always been of high priority for any production.

As mentioned in Chapter 1, one of economical ways to reduce deformations in metal structures of freight wagons, which appear under welding, is the thermal straightening with local heating. At the same time, the problem to improve production and maintenance technologies for freight wagons based on scientific substantiation of the thermal straightening of their elements at the current stage is advisable to solve with application of techniques and methods of the optimization theory [74, 75], i.e. the optimization research of the thermal straightening in order to reduce deformations in wagon metal structures. Generally, the optimization theory is aimed at finding and identification of the best variants among the great variety of actual alternative solutions with appropriate numerical methods, which can dispose of an exhaustive search for estimation of all possible variants. And the mathematical modelling plays one of the basic roles; it implies the use of objective mathematical models in optimization research, and methods and algorithms of these studies (search for an optimal solution).

As far as known methods to avoid welding deformations in metal structure production are not sufficient, there are some techniques used in the wagon production to eliminate welding deformations and stresses [22, 76, 77]. They are:

- rolling of welded joints;

- hammering and straightening in order to create displacements with plastic deformations opposite to displacements created by welding;

- local heating which implies concentrated heating of small areas of a deformed structure;

- thermal treatment in clamp assemblies; and

- impulse and vibration loading of welded joints of metal structures or their separate units.

With consideration of the trends mentioned, the proposes a universal mathematical modelling notation of an optimization problem for the thermal straightening of wagon metal structures in order to decrease their postwelding deformations, as problems of limited multifunctional optimization. Generally, the objective of the optimization research is determination of the vector of controlled parameters $\bar{X}^{*}\left(x_{1}, x_{2}, \ldots x_{n}\right)$ called the optimal point which meets all specific restrictions at which the extreme value of the target function (TF) is reached: $F^{*}(\bar{X})$ - the TF value in the optimal point. 
The general notation of the problem for any wagon metal structure has the form:

$$
\begin{gathered}
F(\bar{X}) \rightarrow \text { extremum, } \\
\bar{X} \in Д_{x} \in Д,
\end{gathered}
$$

where $F$ - main optimality criterion chosen according to the main objective of the optimization research;

$\bar{X}$ - vector of variables $\left(x_{1}, x_{2}, x_{3} \ldots x_{n}\right)$, variation of which can change the main criterion $F$. And dependency (2.2) is called the target function (response function);

Д - area of feasible solutions (optimization area), limited by boundaries of variation of variables $x_{i}$ (controlled variables) regardless the functional limitations, i.e. parametrical (direct) limitations $\left(x_{i \max }, x_{i \min }\right)$;

$$
Д=\left\{\left.\bar{X}\right|_{x_{\text {imin }} \leq x_{i} \leq x_{\text {imax }}, i \in[1 ; n]}\right\}
$$

$Д_{x}$ - area of admissible solutions, limited by functional (secondary criteria presented as equations $\psi(x)=0$ or inequations $\varphi(x)>0)$ and parametrical limitations, where the taken (admissible) solution is searched:

$$
Д_{x}=\left\{\left.\bar{X}\right|_{\psi(x)=0 \ldots . . \varphi(x)>0, x_{i \min } \leq x_{i} \leq x_{i \max }, i \in[1: n]}\right\} .
$$

In the final calculation the optimization research problem is reduced to determination of optimal values of variable factors $\left(x_{1}^{*}, x_{2}^{*}, x_{3}^{*} \ldots x_{n}^{*}\right)$, at which the parametric and functional limitations are fulfilled, and the target function takes the extreme (conditionally extreme or rational) value.

The earlier research demonstrated that it is advisable to use the deflection value $f$ for problems of optimization research into the thermal straightening for wagon metal structures in order to decrease their postwelding deformations; this value is the main optimality criterion, as far as deflection is the main welding deformation in the wagon metal structure production.

Considering the chosen criterion, a generalized notation of optimization research into the thermal straightening, aimed at decreasing post-welding deformations, has the following form 


$$
\begin{aligned}
& f(\bar{X}) \rightarrow \min \\
& \bar{X} \in Д_{x} \in Д,
\end{aligned}
$$

where the area of feasible solutions $\not$ is determined by boundaries of the corresponding values of variable factors $x_{i}$ (parametric limitations):

$x_{B a}, x_{Д d}, x_{U e}$ - variable parameters, which characterize geometrical dimensions of heating areas, namely, height, length and width;

$x_{\Pi j}$ - variable parameter, which characterizes the number of heating zones;

$x_{T k}-$ variable parameter, which characterizes the heating temperature $T$ at thermal straightening.

Considering the all above-mentioned, the area of feasible solutions $Д$ can be presented as follows

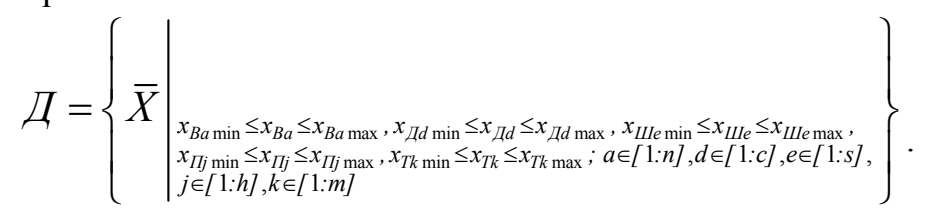

The feasibility region $Д_{x}$ with the solution found is sorted out of the region $Д$ by functional requirements (by secondary criteria limitations). The earlier research demonstrated how the mentioned criteria and limitations corresponding to them should be considered:

$\sigma_{\text {max }}$ - maximum stress in a critical section of the metal structure, which should not exceed the admissible stress $[\sigma]$ for the material chosen;

$c_{\text {max }}$ - rigidity value, which should not exceed the admissible value $[c]$;

$\sigma_{c m . m a x}$ - strength value, which should not exceed the admissible value $\left[\sigma_{c m}.\right]$

$E$ - factor of proportionality (modulus of longitudinal elasticity, elasticity modulus, Young's modulus of elasticity), which is chosen according to the material; for steel it equals $E_{c m}$;

$\eta$ - efficiency of heating for metal structure (within the range from $\eta_{\min }$ to $\left.\eta_{\max }\right)$ 
Thus, the feasibility region $Д_{x}$ is

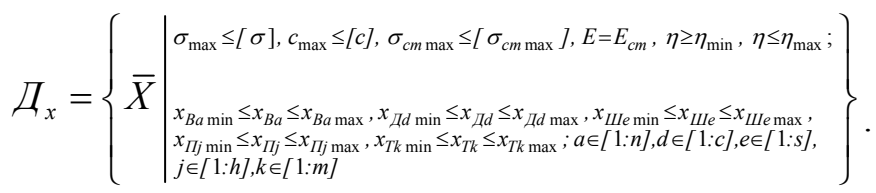

And the general form of the optimization research of the thermal straightening for wagon metal structures has the form

$$
\begin{aligned}
& f(\bar{X}) \rightarrow \text { min } ; \\
& \bar{X} \in Д_{x} \in Д \text {; }
\end{aligned}
$$

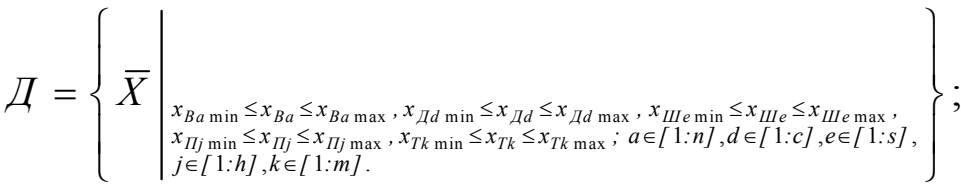

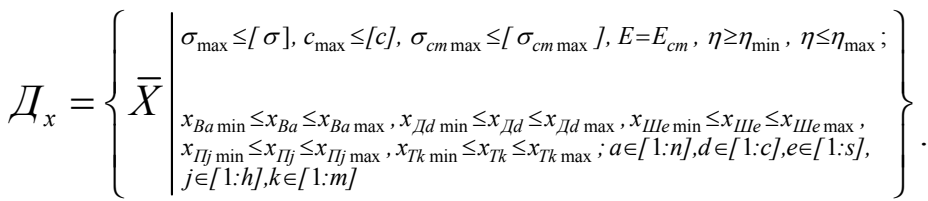

The deflection value for the welded metal structure of a freight wagon is calculated by the formula

$$
f=\frac{M l^{2}}{8 E J},
$$

where $M-$ moment from the action of a pair of axial internal forces;

$$
M=\frac{P_{y c} \cdot h}{2},
$$

where $P_{y c}-$ shrinkage forces, $\mathrm{N}$;

$h$ - height of metal structure before deformation,

$$
P_{y c}=\frac{P_{y c}^{\prime}}{1-\frac{P_{y c}^{\prime}}{\sigma_{T}\left(\frac{e^{2}}{J}+\frac{1}{F}\right)},}
$$


where $P_{y c}^{\prime}$ - initial shrinkage force, $H$;

$F$ - cross-section of welded metal structure;

e - eccentricity of shrinkage force relative to gravity center of cross section.

$$
P_{y c}^{\prime}=B \frac{q}{V_{38}}
$$

where $B=4 \ldots 7$ - non-dimensional coefficient [78], which depends on the specific heat input $q_{0}$ (at $q_{0}=(42 \ldots 63) \cdot 10^{6}$ Дж $/ \mathrm{m}^{2}$ the value $B$ is close to 7 , at $q_{0}=(209 \ldots 293) \cdot 10^{6}$ Дж/ $/ M^{2}$ the value $B$ is close to 4 , at the values $q_{0}=(63 \ldots 209) \cdot 10^{6}$ Дж $/ \mathrm{M}^{2}$ the value $B$ is defined with linear interpolation).

$$
q_{0}=\frac{q}{\delta \cdot V_{H}}
$$

where $V_{H}$ - heating speed, $\mu / c$;

$q$ - efficient heat capacity of a gas oxide flame, Дю $c$;

$\delta$ - width of welded elements (mean thickness of welded elements, if their thicknesses are different), $M$.

$$
q=\frac{\eta \cdot Q \cdot V_{n}}{3600}
$$

where $\eta$ - effective efficiency of heating for metal structure with a gas flame (for production of wagon metal structures $\eta=0,8 \ldots 0,95$ ) [8];

$Q$ - lower heating value of the fuel, кДж / ${ }^{3}$;

$V_{n}$ - volume flow of the fuel, $m^{3} /$ год;

$l$ - length of metal structure before deformation;

$E$ - coefficient of proportionality (called modulus of longitudinal elasticity, modulus of elasticity, or Young's modulus of elasticity);

$J$ - axial inertia moment.

The geometrical dimensions of wedge-like heating zones (the most popular in straightening welded wagon metal structures) are the height $h_{\kappa л}$, which for straightening the center sill is in the range $20 \ldots 24 \%$ out of its 
height, and for straightening the top cord is $45 \ldots . .85 \%$ out of the top cord's height, and width calculated by the formula

$$
b_{\kappa л}=\frac{4 h f}{l \cdot\left(\alpha_{t} \cdot T_{n л}-\varepsilon_{T}\right)},
$$

where $\alpha_{t}$ - linear expansion coefficient for steel, $1 /{ }^{\circ} \mathrm{C}$.

$$
\alpha_{t}=\frac{1}{l} \frac{\Delta l}{\Delta T},
$$

where $\Delta l$ - elongation of the metal structure under an increase in its temperature by value $\Delta T$;

$T_{n л}$ - temperature of heating to the plastic state, ${ }^{\circ} \mathrm{C}$;

$\varepsilon_{T}-$ deformation of material, which corresponds to reaching the yield boundary (at normal temperature).

$$
\varepsilon_{T}=\frac{\sigma_{T}}{E}
$$

where $\sigma_{T}$ - yield boundary of material.

The number of wedges $n$ to be heated for elimination of the residual deformation of a metal structure is calculated by the formula presented below [72].

$$
n=\frac{h f}{2 l\left(\alpha_{t} \cdot T_{n л}-\varepsilon_{T}\right)} .
$$

According to science and technology [79], heating temperature is chosen in the range from $500^{\circ} \mathrm{C}$ to $900^{\circ} \mathrm{C}$. It was experimentally established that the optimal temperature for local heating is in the range from $800^{\circ} \mathrm{C}$ to $850^{\circ} \mathrm{C}[80]$.

\subsection{Mathematical modelling of straightening processes in open wagon element production}

The analysis of recent research and publications demonstrated that today the number of welding techniques by type of activation energy is over a hundred, and the number of arc welding exceeds a thousand. Therefore, 
there is a great variety of possibilities to build mathematic models of welding processes and their improvements. It should be mentioned that a mathematic model of the stress-strain behaviour of open wagon elements in welding or thermal straightening consists of two mutually coupled problems: temperature and deformation.

The research into a deformational problem, and the kinetics of welding stresses and deformations, presented in the, demonstrated that in production of the center sill of an open wagon there appears a considerable deflection (from $65 \mathrm{MM}$ to $110 \mathrm{MM}$ ), which should be reduced [69] (detailed calculation of deformations is given in Appendix C). The study analyzed modern methods and approaches to straightening of deformations under welding carrying metal structures of freight wagons and their elements, and proposed a classification of straightening methods used for welded structures in wagon production. It was established that the most popular method is the thermal straightening with local heating as more economical in comparison with others [67].

Besides, known analytical solutions to the thermal conductivity usually do not consider the heat of transformation of the first kind, accompanied by absorption or emission of the hidden heat, and change of the specific volume.

The academician M.M. Rikalin developed the general theory of heat distribution under heating for estimation of the temperature field [32]; the results demonstrated that the heat of fusing considerably affects the dimensions of the molten metal and the joint. It should be mentioned that the theory of thermal processes by M.M. Rikalin is based on the method of sources, which is efficient when a heating source is concentrated in a small volume of the element, and the heat expansion area is not limited. It enables to find speeds of welding stresses and deformations with numerical methods, but determinates require application of numerical differentiation formulae which give additional errors. However, Rikalkin's method of temperature field calculation does not consider the heat of transformation. All this helped find the most optimal approach, which considered the above-mentioned shortcomings and presented a more accurate description of the temperature field with consideration of the heat of phase transition according to thermophysical temperature coefficients, which led to a Stefan problem formulated by Austrian engineer and metallurgist Josef Stefan as early as in 1870s.

It was the way to research the temperature field under heating during butt welding of two thin plates of a constant thickness and restricted by size [81]. Research of straightening and welding processes requires the problems which can be considered as Stefan ones, but they have a peculiarity that an unknown function which describes the law of transition surface motion of the 
first kind, is included not only in Stefan's conditions, but in the thermal conductivity equation.

The Stefan-type problems belong to non-linear boundary problems for parabolic equations with discontinuous coefficients on unknown moving surfaces. The monograph by L.I. Rubinstain [82] presents the generalized research into correctness of such problems. The existing numerical methods for a Stefan task can be divided into two groups: methods with an explicit selection of the transition boundary, and methods based on substitution of an equivalent thermal conductivity task with a heat source connected to the transition boundary. A characteristic feature of the second group is the use of a homogeneous difference scheme for solutions to the problem.

A lot of mathematic models, while building equations of thermal conductivity, define the spatial distribution of a heat source with the Dirac delta function, introduced by English mathematician Paul Dirac, which later on obtained his named ( $\delta$ function, Delta function). While being built a difference scheme is approximated with the Delta function, which sets smearing of the phase transition enthalpy on a certain phase interface. Thus, it is supposed that the phase transition heat emits at some area of the transition surface $\left(T_{*}-\Delta, T_{*}+\Delta\right)$, where the main supposition under modelling phase transformations is that the phase transition is conducted at a specific constant phase transition temperature of the first kind $T_{*}$, i.e. the phase transition begins at the temperature lower than the melting temperature (crystallization).

The phase (structural) transformations greatly affect residual stresses and deformations under welding and straightening, and estimation of them gives considerable errors. At the same time structural changes in metal during the gas welding are greater than changes during the arc welding due to smoother heating of the impact zones. Under the gas straightening metal undergoes phase structural changes at the heating stage in an interval of temperature $A_{1} \ldots . . A_{3}$ and higher (for Steel 09G2S the temperature of phase transformation beginning is $A_{1}(\mathrm{PSK})=725^{\circ} \mathrm{C}$, the temperature of recrystallization stoppage is $\left.A_{3}(\mathrm{GS})=860{ }^{\circ} \mathrm{C}\right)$. The heat temperature of the base metal which provides the best effect under straightening low-carbon steels is $t=700 \div 750{ }^{\circ} \mathrm{C}$, and the maximum admissible temperature is $t_{\text {max }}=900 \div 950{ }^{\circ} \mathrm{C}$ [79]. Experiments have proved that correction with 
local heating is the most rational at the temperatures from $800^{\circ} \mathrm{C}$ to $830^{\circ} \mathrm{C}$ [72], which is in the range from $600^{\circ} \mathrm{C}$ to $950^{\circ} \mathrm{C}$ according to [79].

Among the basic phase transition temperatures for Steel $09 \Gamma 2 C$ are [83]:

- normalization - area of the base metal in which the fine-grain structure of the best mechanical properties is formed. The temperature fluctuates from $860^{\circ} \mathrm{C}$ and higher (ferrite-to-austenite transformation);

- incomplete re-crystallization - base metal area where the fine-grain structure is formed near the coarse-grain structure through re-crystallization. The temperature fluctuates in a range of $725 \div 860{ }^{\circ} \mathrm{C}$ (ferrite-austenite partial transformation under heating);

- re-crystallization - part of the base metal characterized by the renovated form and sizes of damaged metal grains which were earlier treated by pressure. The temperature fluctuates in a range of $600 \div 725^{\circ} \mathrm{C}$. Heating below $725^{\circ} \mathrm{C}$ does not change the output phase steel composition; however at the temperature over $600^{\circ} \mathrm{C}$ (re-crystallization temperature) it leads to elimination of congenital rolling structure of the base material and spheroidization of the grain form. And the finite structure of the thermal impact zone under straightening depends on the cooling speed of points. This phenomenon is presented in a diagram of anizothermal decomposition of austenite (continuous-cooling transformation diagram) [32].

Below are the materials how to reduce a Stefan problem to a heat conduction problem with a mobile heat source under straightening with an arc gas burner for center sill elements.

In the chosen coordinate system its origin was on the edge of Z-like profiles, the $O x_{2}$ axis was directed along the axis of weld joint $O x_{1}$ along the edge of $\mathrm{Z}$-profile, perpendicular to the axis $\mathrm{Ox}_{2}$. By considering symmetry relative to the axis $O x_{1}$ let us consider one Z-profile $\Omega=\left\{0<x_{1}<l_{1}, 0<x_{2}<l_{2}\right\}$ Fig. 2.4. And the problem of defining the temperature field at straightening is reduced to solution of such an equation system [81]:

$$
c \frac{\partial T}{\partial t}=\operatorname{div}(\lambda \operatorname{grad} T)-\frac{2 \alpha}{\delta}\left(T-T_{c}\right)+q,\left(x_{1}, x_{2}\right) \in \Omega, t>0,
$$

where

$$
c=\left\{\begin{array}{l}
c_{1}, T<T_{*} \\
c_{2}, T>T_{*}
\end{array}, \lambda=\left\{\begin{array}{l}
\lambda_{1}, T<T_{*} \\
\lambda_{2}, T>T_{*}
\end{array},\right.\right.
$$




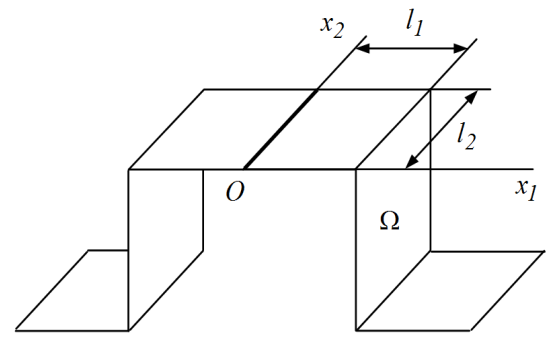

Fig. 2.4. Coordinate system for straightening center sill of open wagon

where $c_{1}\left(c_{2}\right), \lambda_{1}\left(\lambda_{2}\right)$ - volumetric specific heat and heat conductivity factor of solid (liquid) phase, respectively;

$\alpha$ - heat transfer coefficient;

$\delta$ - thickness of beam elements;

$T_{c}$ - environmental temperature at straightening (heating temperature $650 \div 900^{\circ} \mathrm{C}$, non-complete re-crystallization, over-crystallization, normalization of material of open wagon frame);

$T_{*}$ - phase transition temperature.

$$
T=T_{*}([\lambda \operatorname{grad} T], \operatorname{grad} \varphi)+L \frac{\partial \varphi}{\partial t}=0, \varphi\left(x_{1}, x_{2}, t\right)=0, t>0,
$$

where $L$ - crystallization heat of volumetric unit of material;

$\varphi\left(x_{1}, x_{2}, t\right)=0-$ heat boundary equation;

$g$ - specific thermal flow of burner flame with boundary conditions:

$$
\begin{gathered}
-\lambda \frac{\partial T}{\partial x_{1}}+\alpha\left(T-T_{c}\right)=0, x_{1}=0, t>0 ; \\
\lambda \frac{\partial T}{\partial x_{1}}+\alpha\left(T-T_{c}\right)=0, x_{1}=l_{1}, t>0 ; \\
\frac{\partial T}{\partial x_{2}}=0, x_{2}=0, t>0 ; \\
\lambda \frac{\partial T}{\partial x_{2}}+\alpha\left(T-T_{c}\right)=0, x_{2}=l_{2}, t>0 ;
\end{gathered}
$$

with initial condition

$$
T\left(x_{1}, x_{2}, 0\right)=T_{c},\left(x_{1}, x_{2}\right) \in \Omega .
$$


Under actual straightening the heat flow is distributed in some compact space, thus there exists a distributed heating source. Thus, for a surface heating source, e.g. a gas flame, it is experimentally established that the specific heat flow $q$ in any point of the heating spot is described by the Gaussian curve (the normal distribution law) [32] and approximately it can be expressed by the formula

$$
q=q_{\max } \cdot e^{-R k^{2}}
$$

where $q_{\text {max }}$ - largest heat flow in heating zone center, кал $/ \mathrm{cm}^{2} c$;

$e$ - base of natural logarithm;

$R$ - heat flow concentration factor, $1 / \mathrm{cm}^{2}$, (for gas welding $\left.R=0,3 \mathrm{~cm}^{-2}[32]\right)$;

$k$ - radial distance of heat spot point from flame axis, $c M$.

In equation (2.19) the expression $\frac{2 \alpha}{\delta}\left(T-T_{c}\right)$ considers the heat conductivity from both surfaces of Z-like profiles. The Derichlet's boundary conditions (2.21), (2.22), (2.24) establish the condition of heat exchange on elements flanges with the environment. The Newmann's boundary condition (2.23) sets symmetry along the axis $O x_{1}$ in any time moment.

Thus, two-dimensional Stefan problem (2.19), (2.20) with the fixed phase transition temperature $T_{*}$ is reduced to a heat conduction problem with a heat source distributed in a small area on the phase boundary; it is chosen in the phase zone under formation. Due to continuous change in position of the phase transition surface, the heat source added is mobile with the phase boundary.

The heat source is described with the partially continuous integral function $g(T)$ which satisfies the following conditions

- $g(T)$ defined in the whole range of temperature change, non-zero in a range from $T_{*}$ to $T_{*}+\Delta$, and beyond them identically equals zero;

- $g(T)=1$;

- $\frac{\partial g}{\partial T}<0$ for $T \in\left(T_{*}, T_{*}+\Delta\right)$.

Thus, the above-mentioned Stefan problem (2.19) - (2.21) is correct, it is equivalent to the heat conduction problem defined by the equation 


$$
c \frac{\partial T}{\partial t}=\operatorname{div}(\lambda \operatorname{grad} T)-\frac{2 \alpha}{\delta}\left(T-T_{c}\right)+q+L \frac{\partial g}{\partial t},\left(x_{1}, x_{2}\right) \in \Omega, t>0,
$$

with the boundary and initial conditions of the problem $(2.21)-(2.25)$.

In its turn the condition $\frac{\partial g}{\partial T}<0$ provides positivity of the expression $c-L \frac{\partial g}{\partial t}$. In the melting problem $\frac{d T}{d t}>0$, then $\frac{\partial g}{\partial t}=\frac{d g}{d T} \cdot \frac{\partial T}{\partial t}<0$, thus the last summand of the right part of equation (2.27) means a heat leakage which corresponds to the phase transition absorption.

By the method based on the concept of study [68], let us consider some volume $\mathrm{V}$, restricted by the surface $A$ with the phase boundary $\Sigma$ (Fig.2). 5 .

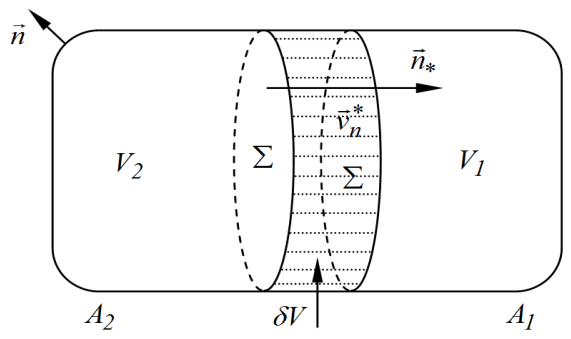

Fig. 2.5. Volume with phase boundary

In the time moment $t$ the phase boundary $\sum$ divides the area $V$ in two sub-areas $V_{1}, V_{2}$ with the external surfaces $A_{1}, A_{2}$. For a certain time gain $\Delta t$ the phase boundary $\sum$ undergoes the elementary volume gain $\delta V$ and takes the position $\Sigma^{\prime}$. At the same time the volume taken by phase 2 increases and, consequently, the volume of phase 1 decreases.

If we integrate equation (2.27) by volume $\mathrm{V}$ with Gauss theorem, we will obtain

$$
\int_{V} c \frac{\partial T}{\partial t} d V=\int_{A}(\lambda \operatorname{grad} T, \vec{n}) d A+\int_{V} L \frac{\partial g}{\partial t} d V+\int_{V}\left(f-\frac{2 \alpha}{\delta}\left(T-T_{c}\right)\right) d V,
$$

where $\vec{n}$ - outward normal to the surface $A$.

Let us work out the second integral of the right part (2.28) 


$$
\begin{aligned}
& \int_{V} L \frac{\partial g}{\partial t} d V=\int_{V_{1}} L \frac{\partial g}{\partial t} d V+\int_{V_{2}} L \frac{\partial g}{\partial t} d V= \\
& =\int_{V_{1}-\delta V} L \frac{\partial g}{\partial t} d V+\int_{V_{2}+\delta V} L \frac{\partial g}{\partial t} d V .
\end{aligned}
$$

Here, the integral over domain $V_{1}-\delta V$ equals zero by the function $g(T)$, and the second integral by $V_{2}+\delta V$ has the form

$$
\int_{V_{2}+\delta V} L \frac{\partial g}{\partial t} d V=\int_{V_{2}} L \frac{\partial g}{\partial t} d V+\lim _{\Delta t \rightarrow 0} \int_{\delta V} L \frac{(g)_{1, t+\Delta t}-(g)_{2, t}}{\Delta t} d V .
$$

By the function $g(T)$ we get that $(g)_{1, t+\Delta t}=0$ and $g(T)=1$ on the phase surface. When $\Delta t \rightarrow 0$ the ratio $d V / d t$ tends to $v_{n}^{*} \cdot d \sum$, where $v_{n}^{*}-$ local speed of the element $d \sum$ along the normal to it towards the first phase. Besides, the volume $\delta V$ shrinks to the surface $\sum$, thus the integration domain becomes $\sum$. And on the basis of two previous ratios we get

$$
\int_{V} L \frac{\partial g}{\partial t} d V=\int_{V_{2}} L \frac{\partial g}{\partial t} d V-\int_{\Sigma} L \cdot v_{n}^{*} d V
$$

Let us write ratio (2.28) for each phase

$$
\begin{gathered}
\int_{V_{1}} c_{1} \frac{\partial T}{\partial t} d V=\int_{A_{1}+\Sigma}(\lambda \operatorname{grad} T, \vec{n})_{1} d A+\int_{V_{1}} L \frac{\partial g}{\partial t} d V+ \\
+\int_{V_{1}}\left(f_{1}-\frac{2 \alpha}{\delta}\left(T-T_{c}\right)\right) d V ; \\
\left.\int_{V_{2}} c_{2} \frac{\partial T}{\partial t} d V=\underset{A_{2}+\sum}{\int(\lambda \operatorname{grad} T}, \vec{n}\right)_{2} d A+ \\
+\int_{V_{2}} L \frac{\partial g}{\partial t} d V+\int_{V_{2}}\left(f_{2}-\frac{2 \alpha}{\delta}\left(T-T_{c}\right)\right) d V .
\end{gathered}
$$

In equation (2.32) the second summand of the right part equals zero, and in equation (2.33) a similar part is replaced by its value from formula (2.31). And by summing the obtained ratios, we will obtain the equation 


$$
\begin{gathered}
\int_{V} c \frac{\partial T}{\partial t} d V=\int_{A}(\lambda \operatorname{grad} T, \vec{n}) d A+\int_{\Sigma}(\lambda \operatorname{grad} T, \vec{n})_{1} d \sum+\int_{\Sigma}(\lambda \operatorname{grad} T, \vec{n})_{2} d \sum+ \\
+\int_{V} L \frac{\partial g}{\partial t} d V+\int_{\Sigma} L \cdot v_{n}^{*} d \sum+\int_{V}\left(f-\frac{2 \alpha}{\delta}\left(T-T_{c}\right)\right) d V .
\end{gathered}
$$

By deducting equation (2.28) from the obtained ratio we will get

$$
\int_{\Sigma}(\lambda \operatorname{grad} T, \vec{n})_{1} d \sum+\int_{\Sigma}(\lambda \operatorname{grad} T, \vec{n})_{2} d \sum+\int_{\Sigma} L \cdot v_{n}^{*} d \sum=0 .
$$

If the local normal line to $\sum$, directed to the first phase, is indicated as $\vec{n}_{*}$, in the first integral $\vec{n}=-\vec{n}_{*}$, and in the second integral $\vec{n}=\vec{n}_{*}$. And the previous equation can be noted as

$$
\int_{\Sigma}\left[\left((\lambda \operatorname{grad} T)_{2}-(\lambda \operatorname{grad} T)_{1}, \vec{n}_{*}\right)+L \cdot v_{n}^{*}\right\rfloor d \sum=0 .
$$

Therefore, due to randomness of the volume $V$ and the corresponding surface $\sum$ we will get

$$
\left([\lambda \operatorname{grad}], \vec{n}_{*}\right)+L \cdot v_{n}^{*}=0
$$

which considers the ratio

$$
\begin{gathered}
v_{n}^{*}=\frac{1}{|\operatorname{grad} \Phi|}\left(\frac{d \vec{R}}{d t}, \operatorname{grad} \Phi\right), \\
\vec{n}_{*}=\frac{\operatorname{grad} \Phi}{|\operatorname{grad} \Phi|},\left(\frac{d \vec{R}}{d t}, \operatorname{grad} \Phi\right)+\frac{\partial \Phi}{\partial e}=0
\end{gathered}
$$

gives condition (2.20). In the last equation $\vec{r}=\vec{R}(t)$ - radius vector of a point on the transition surface. The check for adequacy of the obtained mathematical model is conducted with numerical calculation of a problem of heating the wagon's elements under straightening; they are presented below. For numerical calculation of equations (2.27), (2.21) - (2.25), let us use the smoothing method. The coefficients of equation (2.27) as temperature functions jump at $T=T_{*}$ and they are not determined in this point. Let us 
join the last term of the right part with the left part, then the effective thermal capacity $c-L d g / d T$ jump at the points $T=T_{*}$ and $T=T_{*}+\Delta$. Therefore, equations (2.27), (2.21) - (2.25) will have the following form

$$
\begin{gathered}
\widetilde{c} \frac{\partial T}{\partial t}=\operatorname{div}(\tilde{\lambda} \operatorname{grad} T)-\frac{2 \alpha}{\delta}\left(T-T_{c}\right)+q,\left(x_{1}, x_{2}\right) \in \Omega, t>0 \\
-\tilde{\lambda} \frac{\partial T}{\partial x_{1}}+\alpha\left(T-T_{c}\right)=0, x_{1}=0, t>0 \\
\tilde{\lambda} \frac{\partial T}{\partial x_{1}}+\alpha\left(T-T_{c}\right)=0, x_{1}=l_{1}, t>0 \\
\frac{\partial T}{\partial x_{2}}=0, x_{2}=0, t>0 \\
\tilde{\lambda} \frac{\partial T}{\partial x_{2}}+\alpha\left(T-T_{c}\right)=0, x_{2}=l_{2}, t>0 \\
T\left(x_{1}, x_{2}, 0\right)=T_{c},\left(x_{1}, x_{2}\right) \in \Omega
\end{gathered}
$$

coefficients of the mathematical notation mentioned above are determined in the whole range of temperature changes by the following way

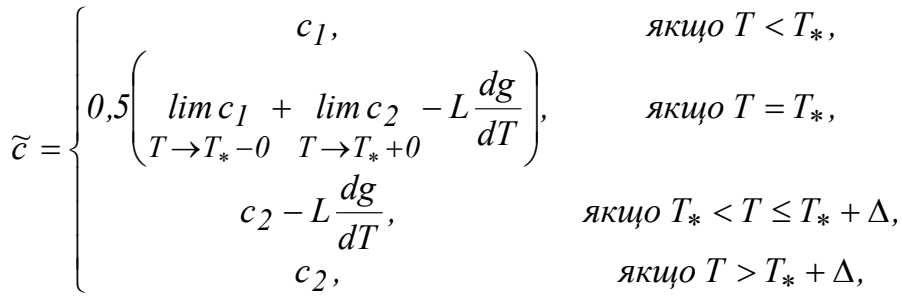

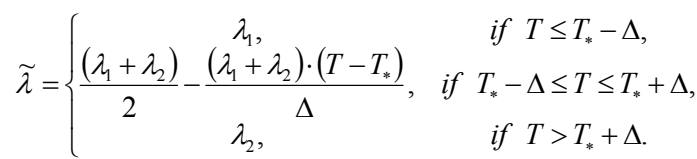

The approximation by continuous function was taken for the thermal coefficient. Therefore, it can be re-defined similarly to the heat capacity. As a temperature field is most sensitive to the value of thermal coefficient, it must, when re-defined, closely match the actual phase transition process. By choosing the function $g(T)$ there is a need to consider the process direction: the phase transition is conducted as a result of a temperature fall or rise. It should differ from zero in the phase zone under the following formation. 
The validity check of the design mathematical model was conducted with the data presented in studies [32, 69, 83, 84].

Fig.2.6 presents the design data in terms of temperature distribution in the center sill of low-carbon steel (345-09G2S-14, GOST 5267.0-90) of 10 $\mathrm{mm}$ in thickness at various time moments from the beginning of heating under welding. And the radius of the heating zone is $10 \mathrm{M}$, the effective capacity of the heating source is 245 Дж/c and the heating time is $30 \mathrm{c}$.

Fig. 2.7-2.10 present design and experimental data regarding temperature distribution in the center sill at the corresponding distances $R$ from the heating center.

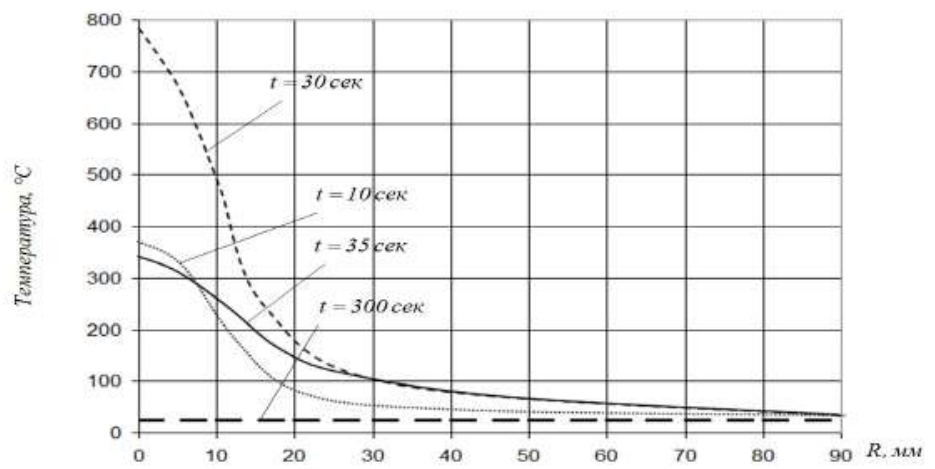

Fig. 2.6. Temperature distribution in center sill

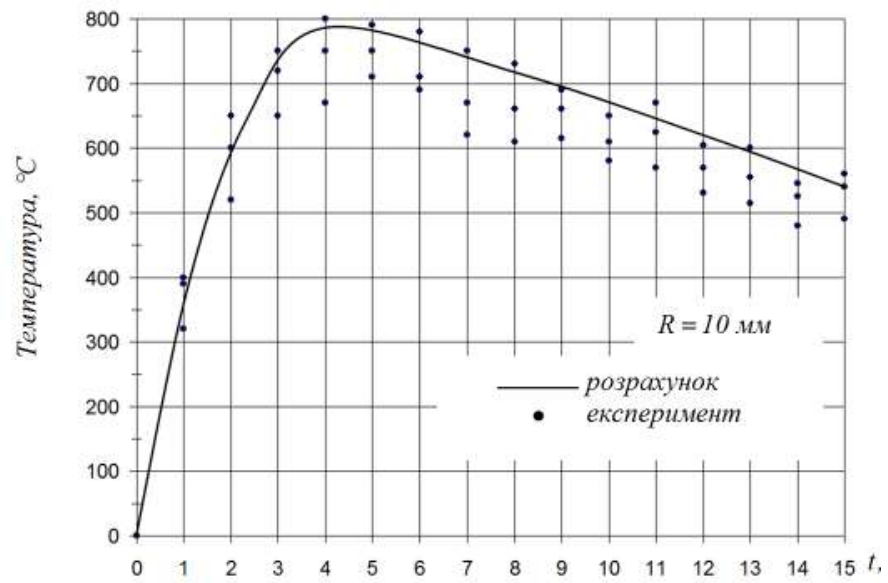

Fig. 2.7. Kinetics of design and experimental temperature values at $10 \mathrm{sm}$ from heating center on beam 


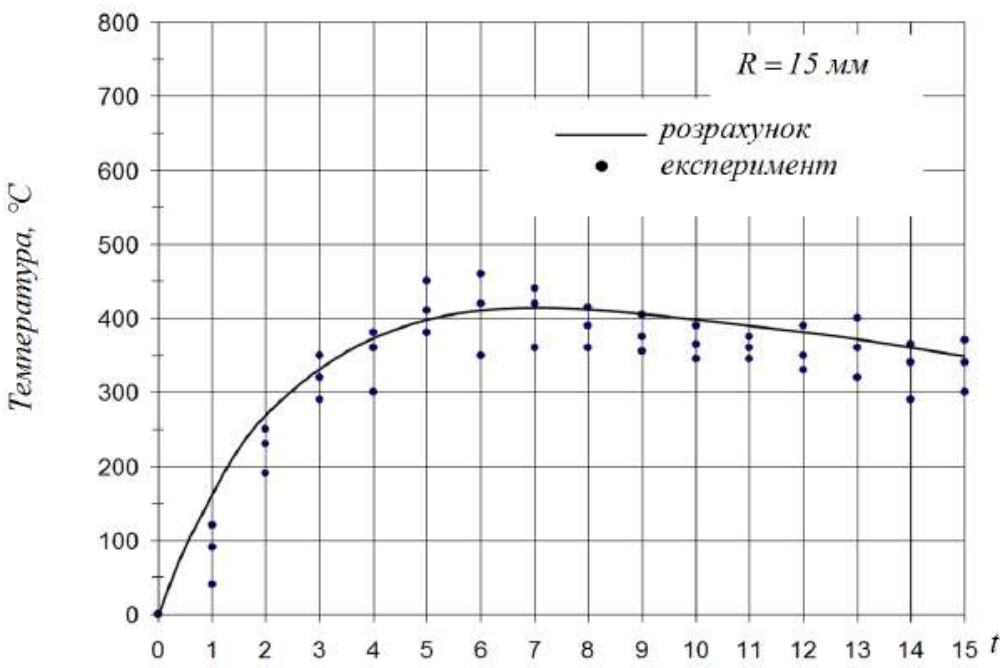

Fig. 2.8. Kinetics of design and experimental temperature values at $15 \mathrm{sм}$ from heating center on beam

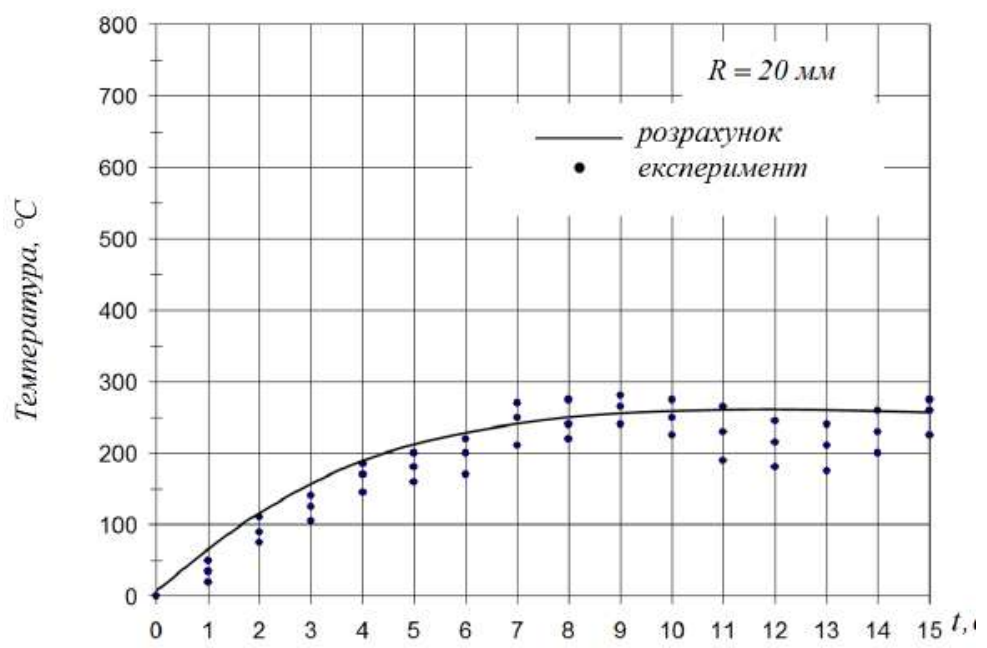

Fig. 2.9. Kinetics of design and experimental temperature values at $20 \mathrm{~mm}$ from heating center on beam 


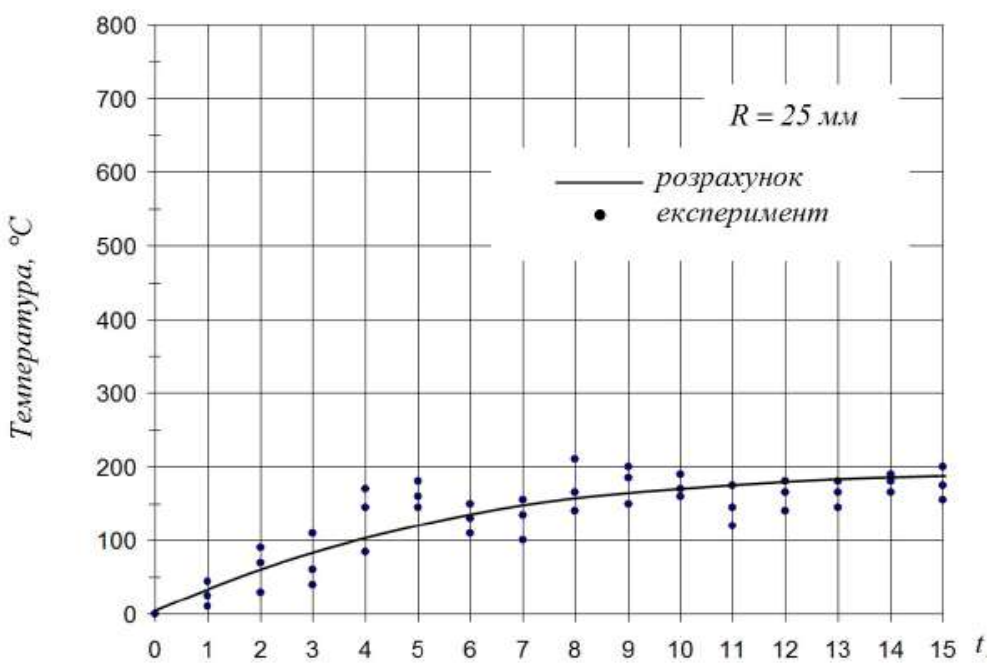

Fig. 2.11. Kinetics of design and experimental temperature values at $25 \mathrm{Mm}$ from heating center on beam

\subsection{Rationale for choosing forms and geometrical parameters of heating zones under thermal straightening for wagon metal structures}

The use of thermal straightening with local heating is connected with the following stages: revealing deformations emerging in the structure;

- measuring these deformations and decompose complex deformations into simple ones;

- $\quad$ establishing location, form, size and heating mode according to the nature and values of the deformations; and

- using a prior elastic heating deformation with subsequent complete cooling of the structure, if needed $[66,85]$.

Among the above-mentioned stages particular attention is given to a choice of heating form and size. According to the existing classification there are the following heating forms: dotted heating along concentric circles; circular heating; spiral heating; heating along bands or rings in consecutive order; heating by triangles (wedges); combination of wedge heating and band heating; cross heating combined with band heating [85, 66, 86].

There are some recommendations for thermal straightening: 
- $\quad$ application of short bands and waviness by free edges for straightening cambers on the shell;

- $\quad$ application of bands on the reverse side of welded shells to straighten ribbings;

- application of triangles (wedges) for straightening deflections of beams; and

- $\quad$ application of a spotted circle for straightening cambers on thin-sheep shells (4 mm and less in thickness).

The number of heating bands, spots and triangles are chosen for a decrease of existing deformations by means of residual plastic deformations to admissible values under heating.

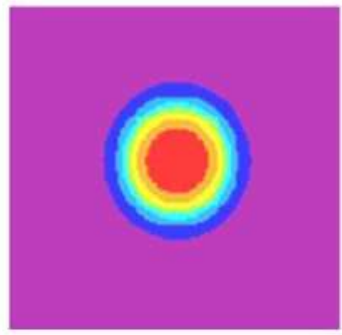

a)

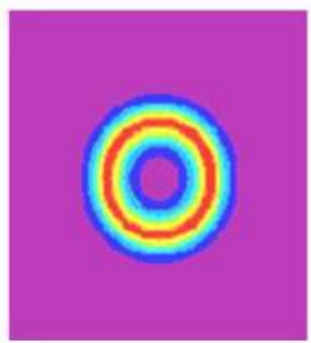

2)

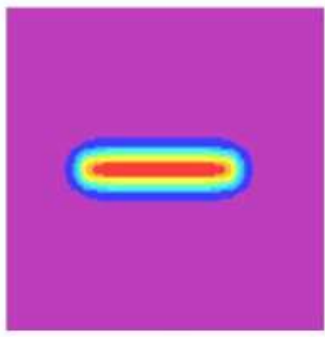

б)

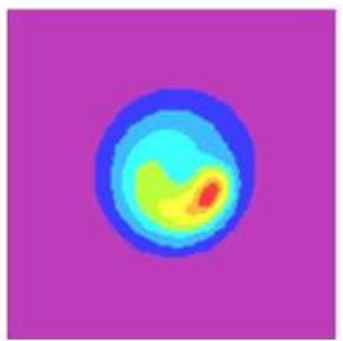

d)

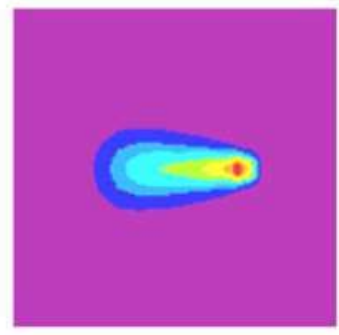

в)

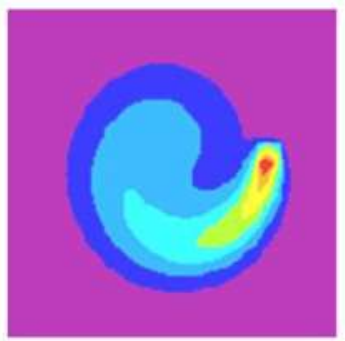

e)

Fig. 2.11 presents examples of local heating forms traditionally used at thermal straightening $[64,73]$.

Fig. 2.11. Forms of heating zones:

a) round heating zone; b) long band with distributed heating source; c) long band with moving heating source; d) circular heating with distributed source; e) circular heating with moving heating source; f) spiral heating with moving heating source 
Analysis of the above-mentioned heating forms indicated that the bending moment needed to straighten the structure can be reached through longitudinal or transverse shrinkage of metal. The heating band is an example of a longitudinal shrinkage of metal at local heating. In its turn transverse shrinkage of metal is used for wedge heating, which increases with approaching the cambered side of an element under deformation. It was established that the thermal straightening for carrying structure elements of freight wagons requires transverse shrinkage of metal and wedge heating.

Fig. 2.12 demonstrates an example of the thermal straightening for elements of freight wagons with wedge heating.
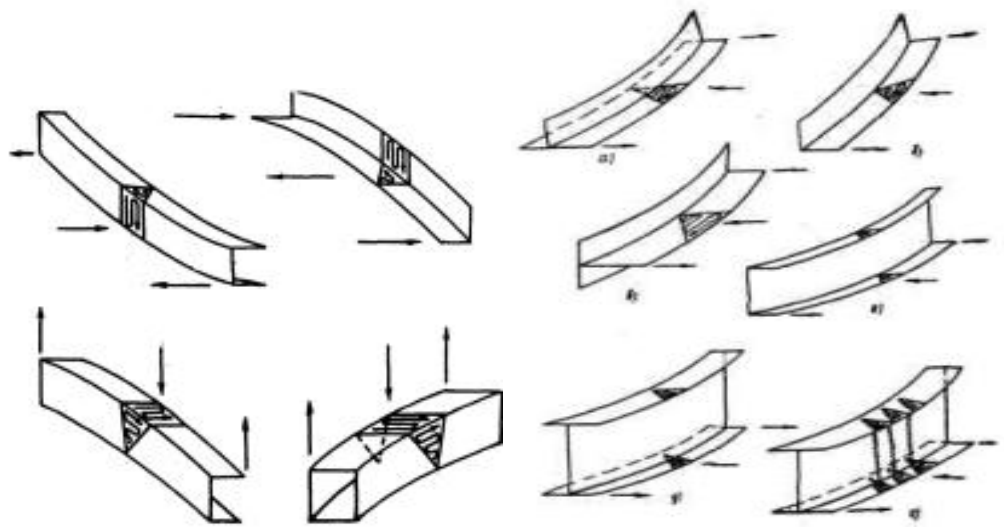

Fig. 2.12. Thermal straightening for post-welded deformations on carrying structure elements of freight wagons with wedge heating method

2.5 Computer modelling of straightening process with application of designed mathematical dependencies

The author proposes the thermal non-impact straightening for the technologically deformed center sill of an open wagon presented in Fig. 2.12; this method is called the method of wedge heating and realized by the internal stressed state generated by thermal impact. This method provides for the heating of triangles (wedges) (Fig. 2.13) on Z-like profiles (Fig. 2.14).

The straightening procedure of the technologically deformed center sill of an open wagon by the above-mentioned method runs as follows. Two gas cutters simultaneously and symmetrically heat equiangular triangles (wedges) (see Fig. 2.14) with heating equipment (at thermal straightening the heating is 
conducted with a gas oxygen flame or an electric arc) on Z-like profiles (see Fig. 2.13, areas 1-4) until steel in the heating zones reaches cherry-red/red colour (corresponding external parts of bottom horizontal flange, fillets and vertical rail of Z-like profiles (Fig. 2.15). After heating all wedges the center sill are cooled in the processing area. After cooling one can see on the beam the vertical positive displacements of mean points so that its longitudinal axle and horizontal line are balanced and even the vertical deflection moves upward (technical documentation admits up to $10 \mathrm{~mm}$ ).

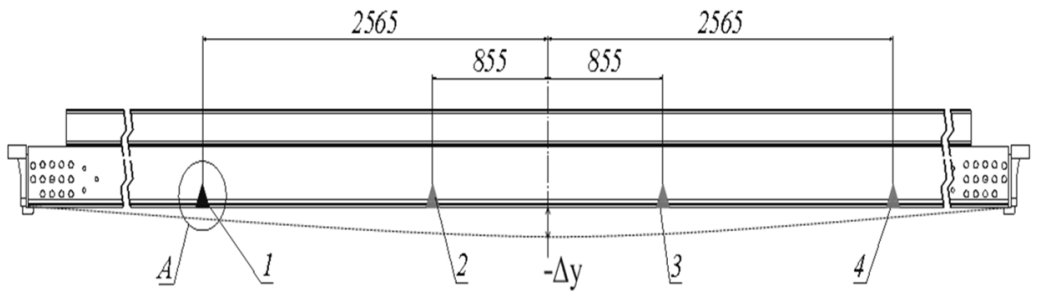

Fig. 2.13. Center sill with areas for heating with wedge method

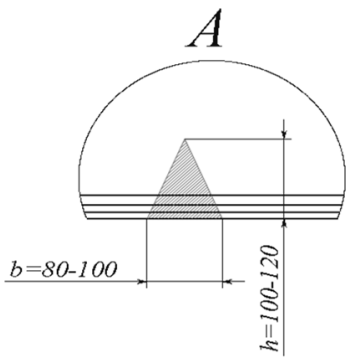

Fig. 2.14. Wedge

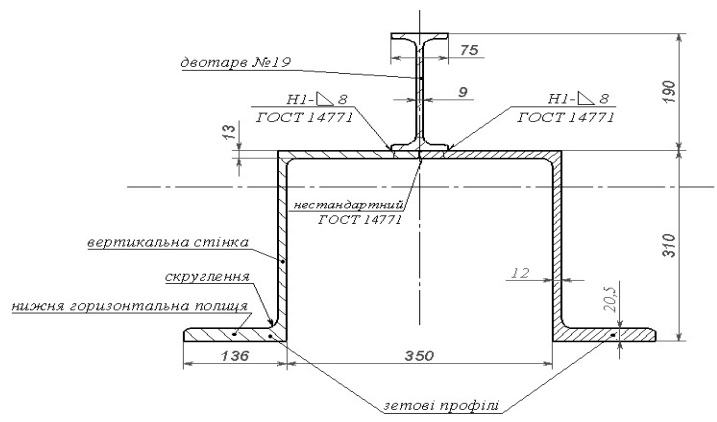

Fig. 2.15. Cross section of center sill 
The basic complexity under thermal straightening is determination of sizes and heating modes. They were determined by mathematical modelling of the thermal straightening for the center sill of an open wagon [66, 68, 85 88]. Fig. 2.16 presents an example of the mathematical research planning for reference and actual parameters, and also determination of the macro-model coefficients.
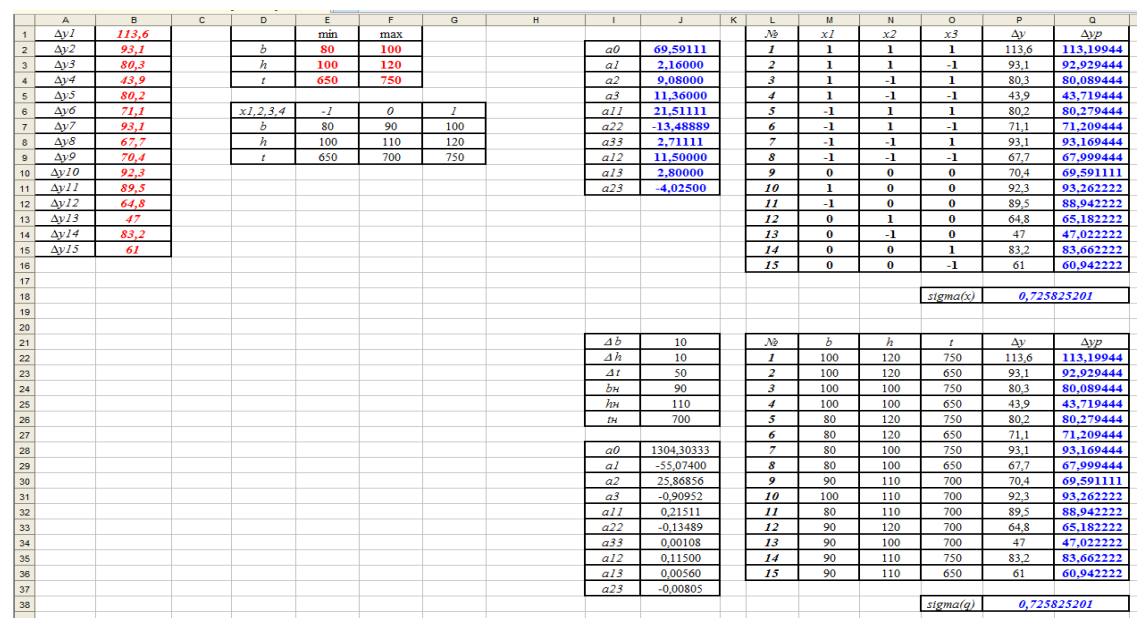

Fig. 2.16. Fragment of program field of calculation of mathematical model of deflection change in center sill of open wagon

Below is given a three-factor generalized mathematical model obtained with the method of mathematical research planning; it describes a change in the basic parameter (beam deflection $\Delta y$ ) depending on changing variables (geometrical parameters of the wedge - width $b$, height $h$ and heating temperature $t$ ) [89] and makes a comparison with variable colours of steel in accordance with DSTU 2658-94 given in Appendix C.

$$
\begin{gathered}
\Delta y=1304,30333-55,074 \cdot b+25,86856 \cdot h- \\
-0,90952 \cdot t+0,21511 \cdot b^{2}-0,13489 \cdot h^{2}+ \\
+0,00108 \cdot t^{2}+0,115 \cdot b \cdot h+0,0056 \cdot b \cdot t- \\
-0,00805 \cdot h \cdot t .
\end{gathered}
$$

The adequacy check of the above-mentioned mathematical model proved its operating capacity and possibility for further application. 
As an example Fig. 2.17 - 2.20 present additional diagrams for defining the geometrical parameters of wedge (at the heating temperatures $500{ }^{\circ} \mathrm{C}, 600^{\circ} \mathrm{C}$ and $700^{\circ} \mathrm{C}$ ) with isolines (lines of equal values) of deflection of the beam.

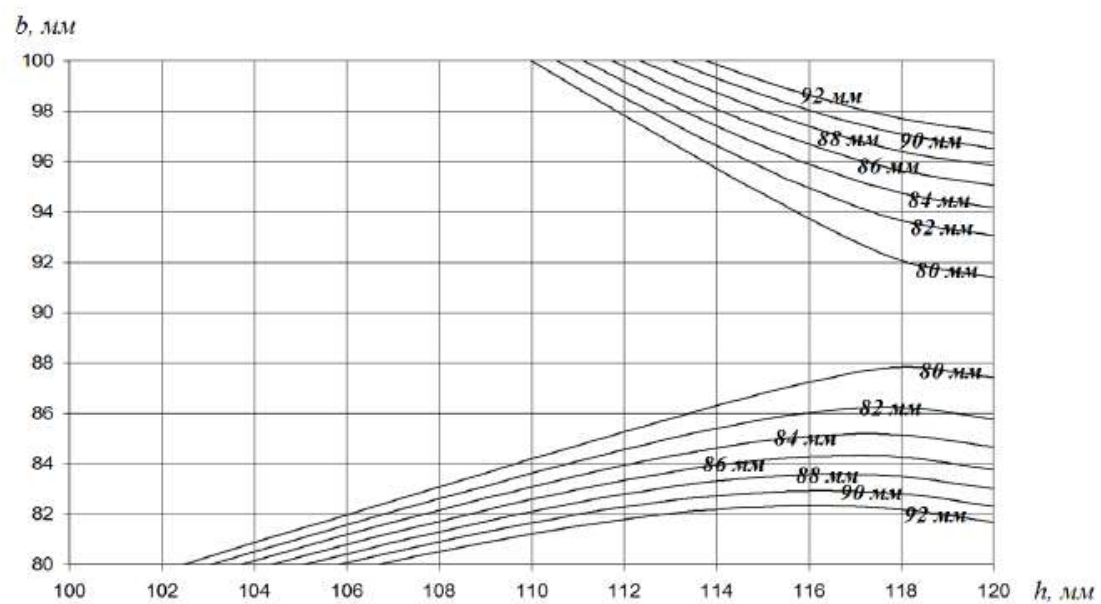

Fig. 2.17. Additional diagram for selection of sizes of wedge $\left(t=500{ }^{\circ} \mathrm{C}\right)$

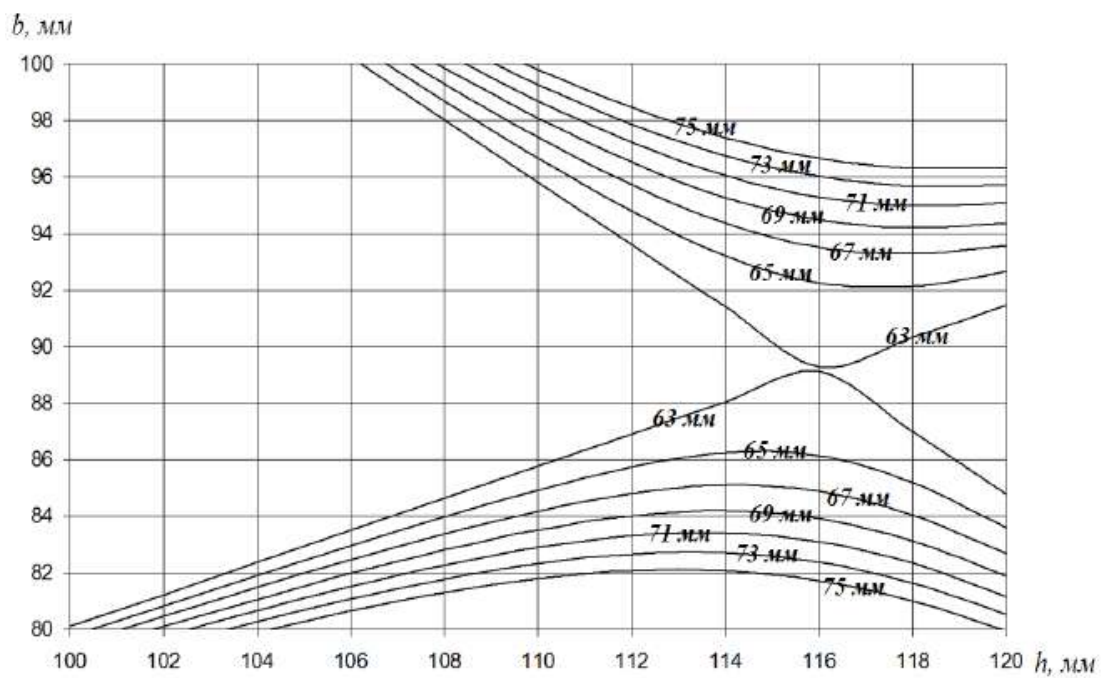

Fig. 2.18. Additional diagram for selection of sizes of wedge $\left(t=600{ }^{\circ} \mathrm{C}\right)$ 


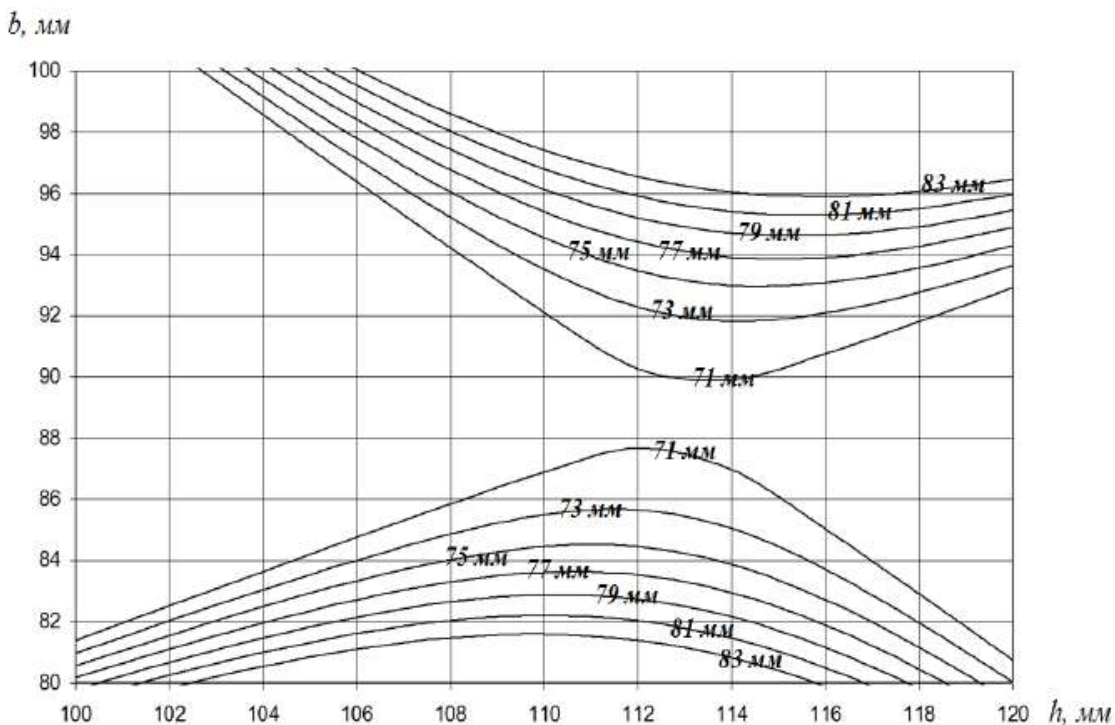

Fig. 2.19. Additional diagram for selection of sizes of wedge $\left(t=700{ }^{\circ} \mathrm{C}\right)$

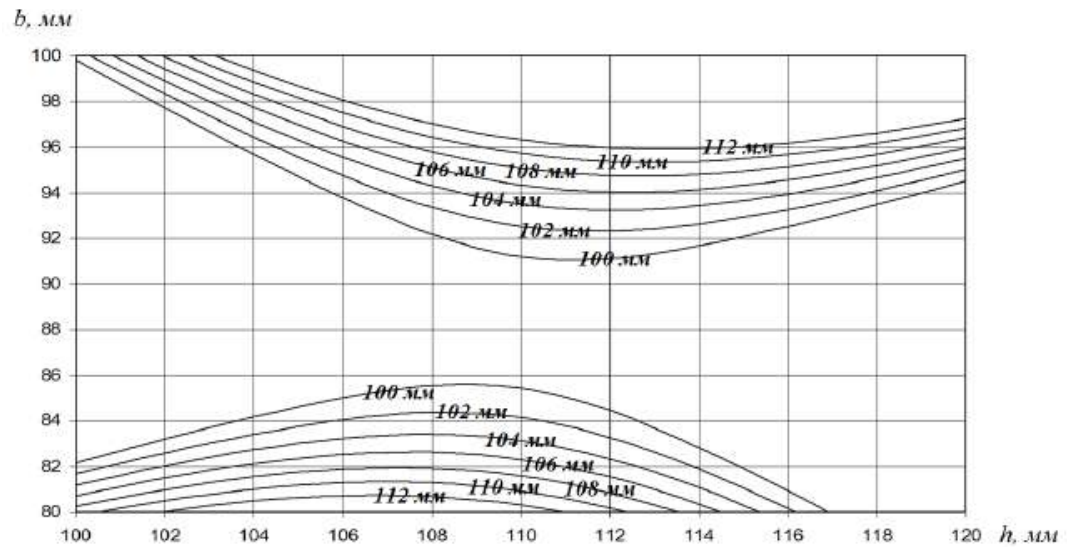

Fig. 2.20. Additional diagram for selection of sizes of wedge $\left(t=790{ }^{\circ} \mathrm{C}\right)$

The author proposes the thermal non-impact straightening for technologically deformed top cord of an open wagon (Fig. 2.21); this method is called the wedge heating and it is realized by internal stressed state through thermal impact. The method consists of short-term heating of triangles (wedges) (Fig. 2.22) in the corresponding external areas on the side (vertical) walls of a profile, the cross section of which is given in Fig. 2.23. 
The straightening of a technologically deformed top cord of the center sill for an open wagon is fulfilled by the following way. Two gas cutters simultaneously and symmetrically heat equiangular triangles (wedges) (see Fig. 2.21) with heating equipment (at thermal straightening the heating is conducted with a gas oxygen flame or an electric arc) on side (vertical) flanges of the profile (see Fig. 2.20, areas 1-8) until steel in the heating zone reaches cherry-red/red colour. After the heating of all wedges, the top cord is cooled in the processing area. After cooling the technologically deformed top cord demonstrates vertical positive displacements of mean points of the profile so that its longitudinal axle is levelled with the horizontal.

The basic difficulty of thermal straightening for the technologically deformed top cord of an open wagon is determination of sizes of forms (here, wedge) and heating modes. They were determined by the mathematical modelling of the thermal straightening process for the technologically deformed top cord of an open wagon [65, 90, 91, 92]; it included building the mathematical planning for the corresponding mathematical models, and building additional nomogramms with their subsequent analysis.

Fig. 2.23, 2.24 and 2.25 present an example of the mathematical research planning for reference and actual parameters, and also determination of the macro-models coefficients.

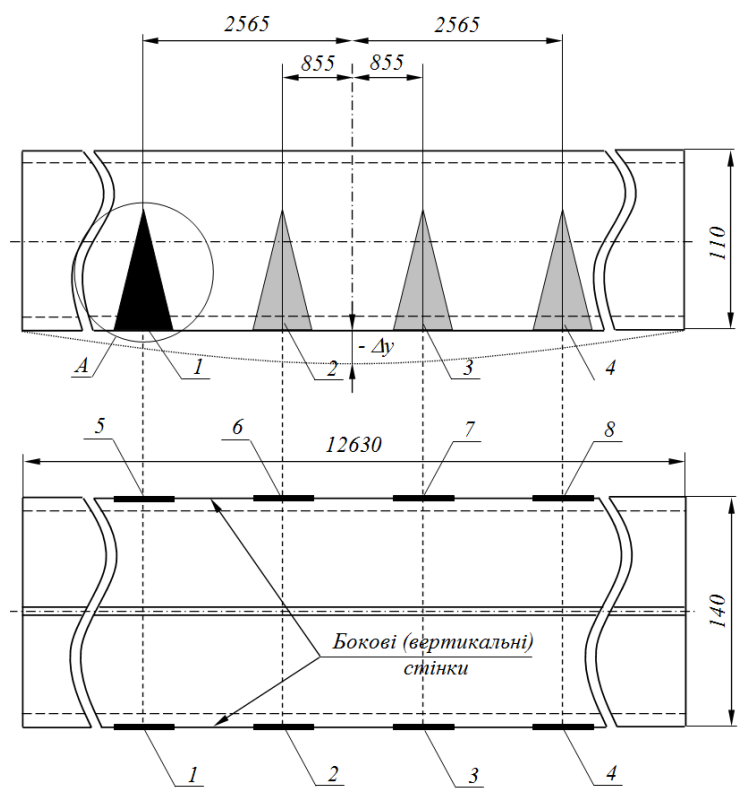

Fig. 2.21. Top cord with areas $(1-8)$ for heating with wedge method 


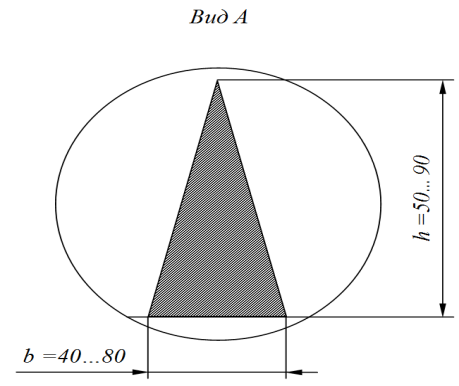

Fig. 2.22. Wedge

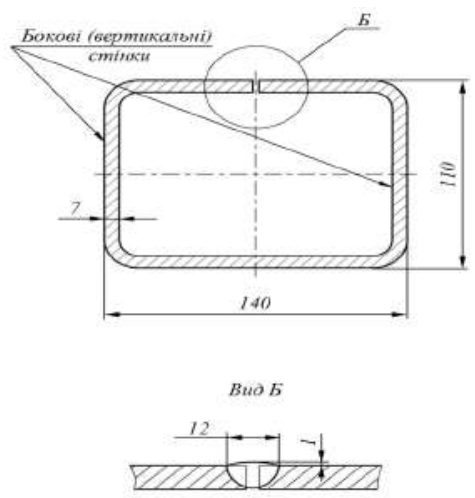

Fig. 2.23. Cross section of top cord

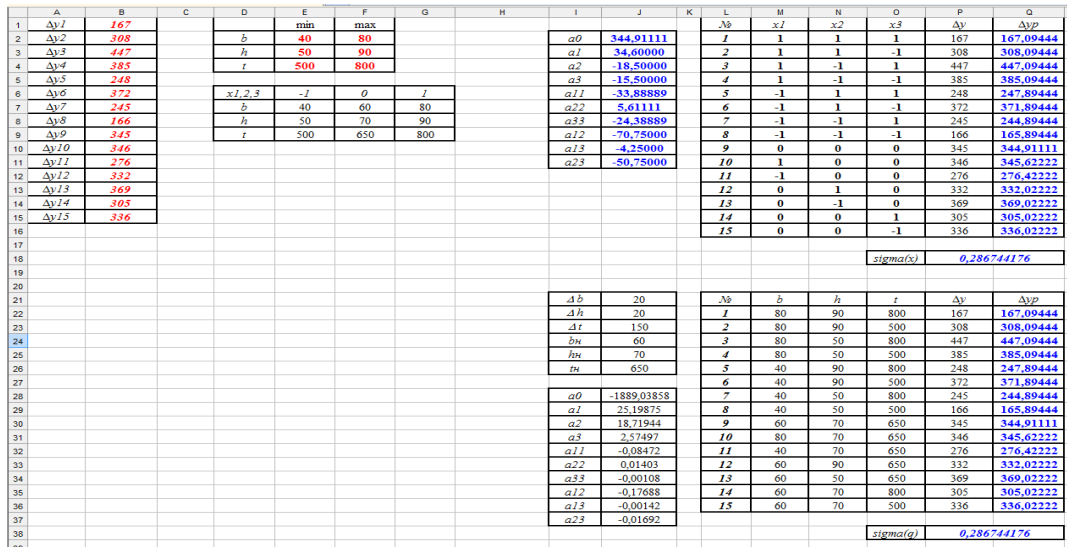

Fig. 2.24. Fragment of program field with calculation of mathematical model of changes in deflection of top cord $\left(\right.$ at $\mathrm{t}=500{ }^{\circ} \mathrm{C}$ and $\mathrm{t}=680{ }^{\circ} \mathrm{C}$ ) 


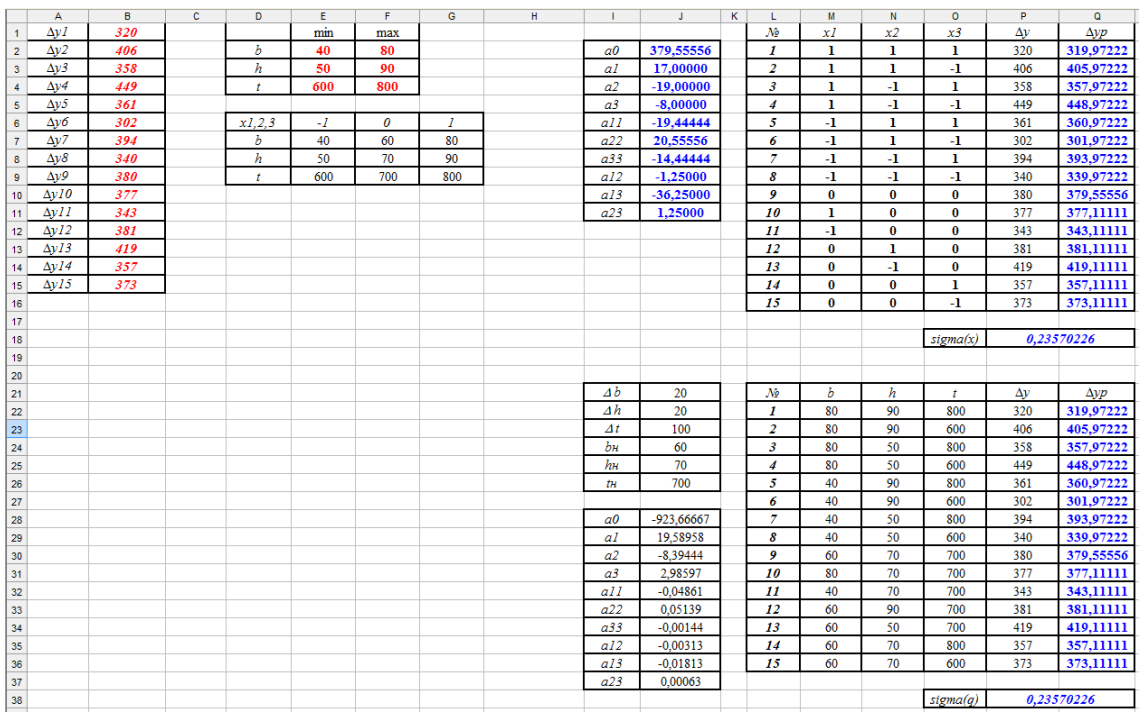

Fig. 2.25. Fragment of program field with calculation of mathematical model of changes in deflection of top cord $\left(\right.$ at $\left.\mathrm{t}=600^{\circ} \mathrm{C}\right)$
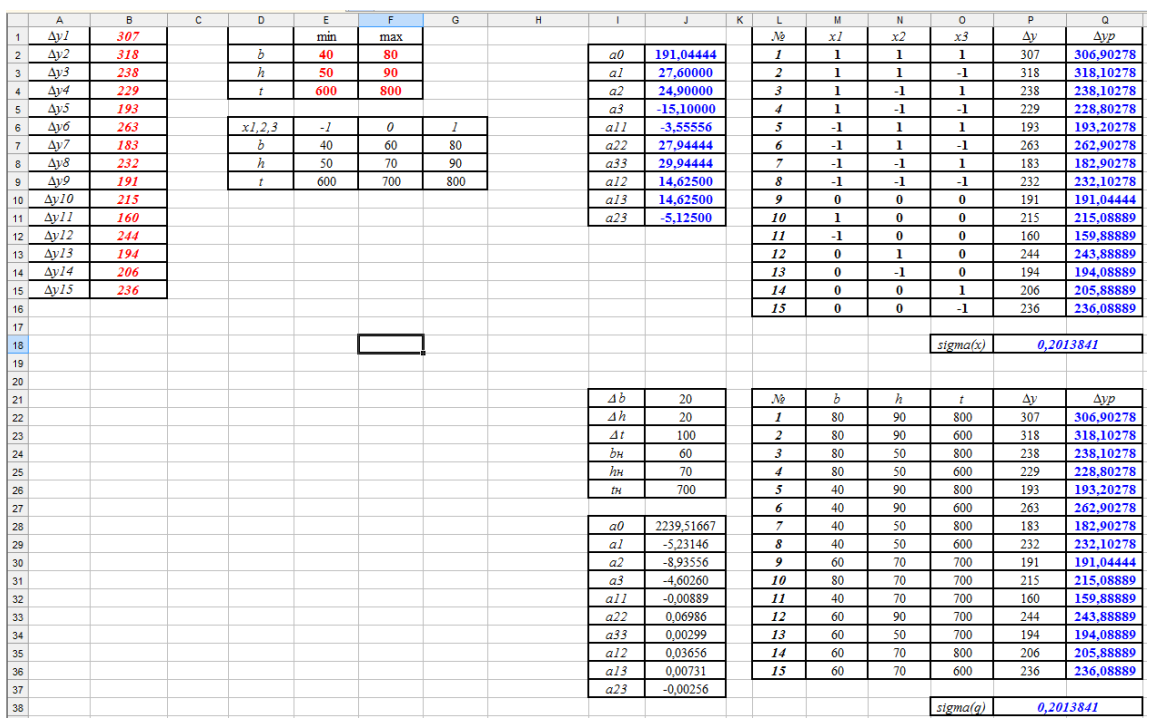

Fig. 2.26. Fragment of program field with calculation of mathematical model of changes in deflection of top cord $\left(\right.$ at $\left.\mathrm{t}=800^{\circ} \mathrm{C}\right)$ 
Below are given three-factor generalized mathematical models (obtained by applying the method of mathematical research planning), which describe changes in the main factor (deflection of the top cord $\Delta y$ ) depending on the variation of guided variables (geometrical parameters of a wedge: wide $b$, height $h$, and heating temperature $t$ ) [93].

$$
\begin{aligned}
& \Delta y=2239,51667-5,23146 \cdot b-8,93556 \cdot h- \\
& -4,60260 \cdot t-0,00889 \cdot b^{2}+0,06986 \cdot h^{2}+ \\
& +0,00299 \cdot t^{2}+0,03656 \cdot b \cdot h+0,00731 \cdot b \cdot t- \\
& -0,00256 \cdot h \cdot t \\
& \Delta y=-3092,45833+25,76542 \cdot b+25,48611 \cdot h+ \\
& +5,16319 \cdot t-0,08472 \cdot b^{2}+0,01403 \cdot h^{2}- \\
& -0,00244 \cdot t^{2}-0,17688 \cdot b \cdot h-0,00213 \cdot b \cdot t- \\
& -0,02538 \cdot h \cdot t \\
& \Delta y=-923,66667+19,58958 \cdot b-8,39444 \cdot h+ \\
& +2,98597 \cdot t-0,04861 \cdot b^{2}+0,05139 \cdot h^{2}- \\
& -0,00144 \cdot t^{2}-0,00313 \cdot b \cdot h-0,01813 \cdot b \cdot t+ \\
& +0,00063 \cdot h \cdot t \text {. }
\end{aligned}
$$

The adequacy check of the above-mentioned mathematical models confirmed their working capacity and possibility for further application.

As an example Fig. 2.27-2.30 give additional diagrams for defining the geometrical parameters of a wedge (at the heating temperatures $500{ }^{\circ} \mathrm{C}, 600^{\circ} \mathrm{C}$ and $680^{\circ} \mathrm{C}$ ) with isolines (the lines of equal values) of deflection of the top cord.

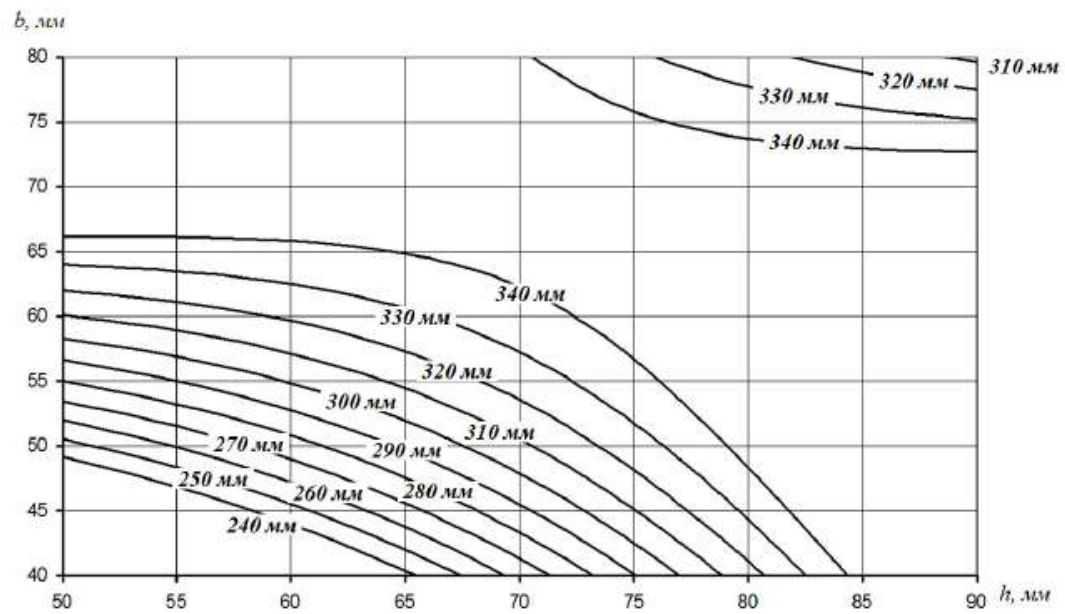

Fig. 2.27. Additional diagram for selection of sizes of wedge $\left(t=500{ }^{\circ} \mathrm{C}\right)$ 


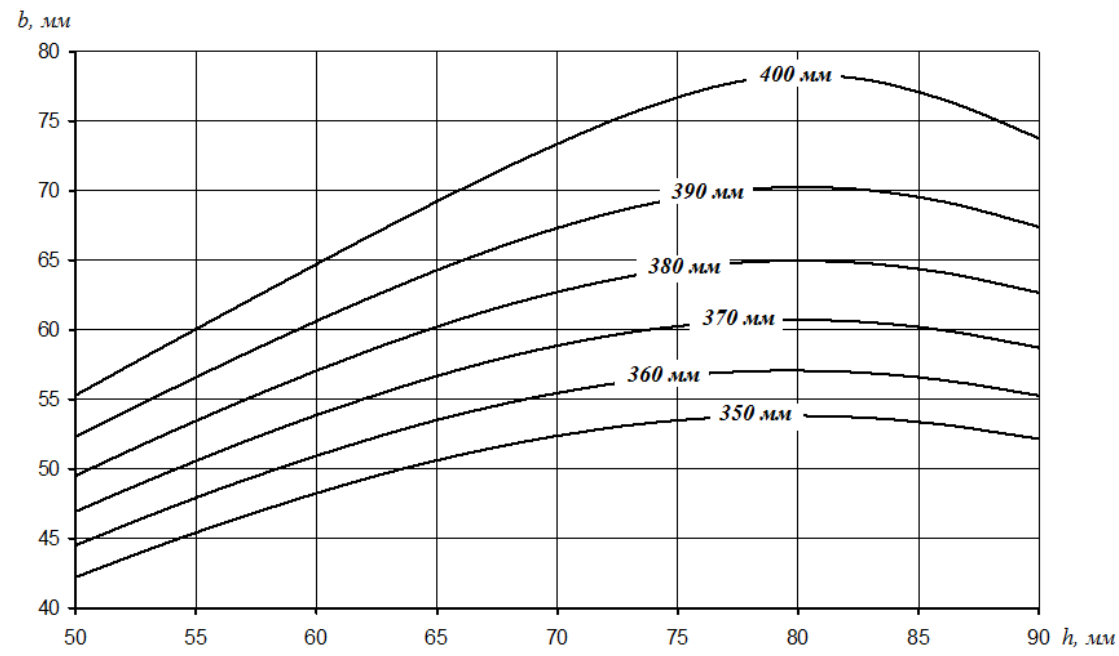

Fig. 2.28. Additional diagram for selection of sizes of wedge $\left(t=600{ }^{\circ} \mathrm{C}\right)$

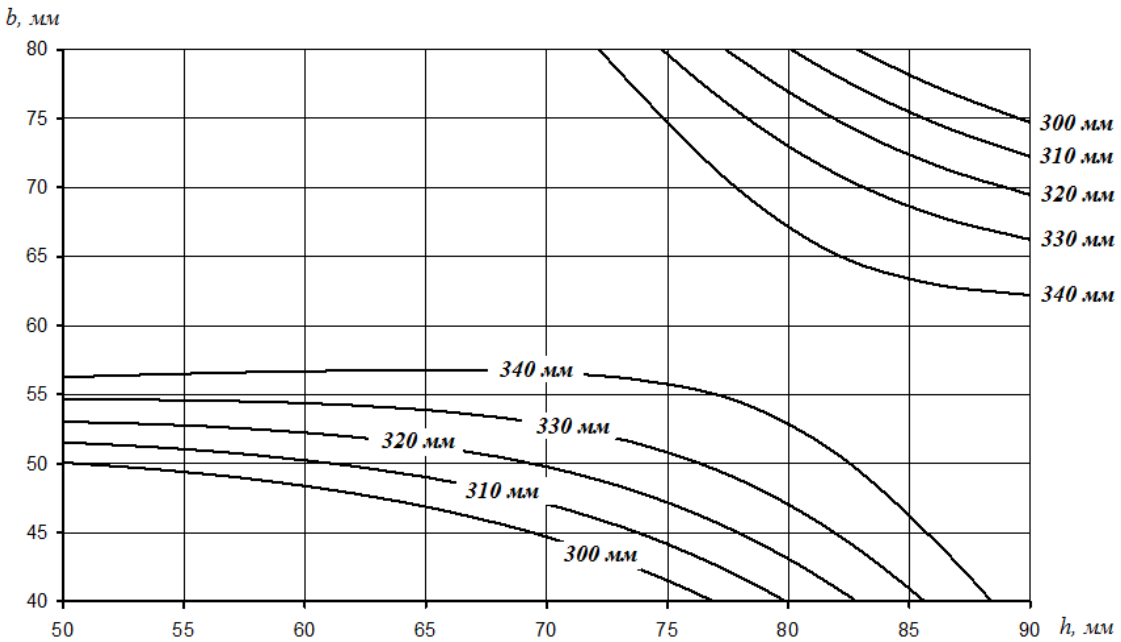

Fig. 2.29. Additional diagram for selection of sizes of wedge $\left(t=680^{\circ} \mathrm{C}\right)$ 


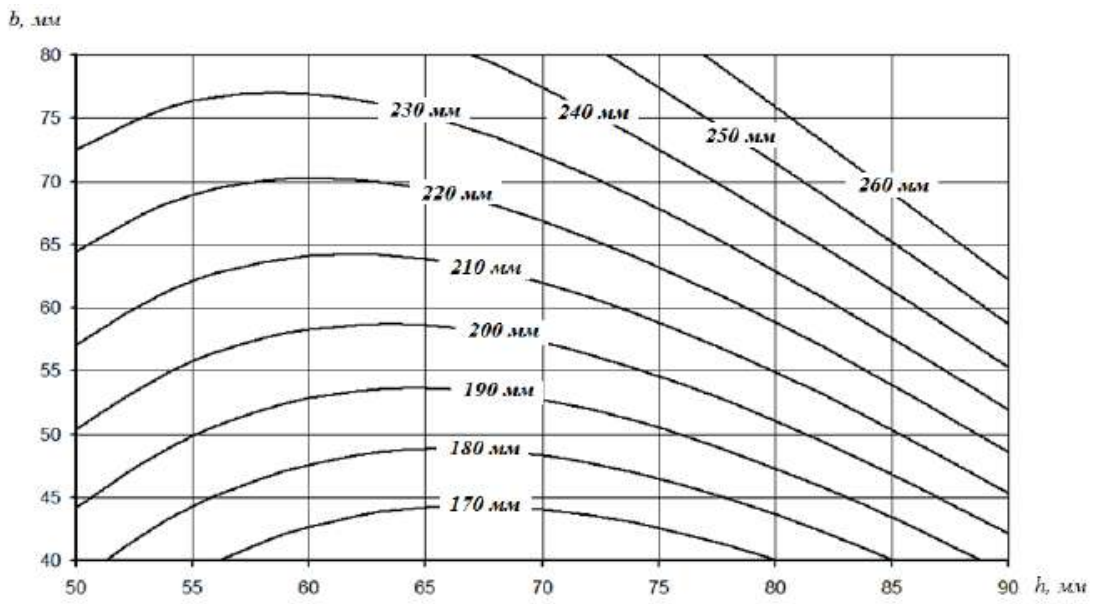

Fig. 2.30. Additional diagram for selection of sizes of wedge $\left(t=800{ }^{\circ} \mathrm{C}\right)$

\section{Conclusions to Chapter 2}

1. The study deals with the physical nature of the thermal straightening. It was mentioned that its application requires heating, which can be divided into three types: heating symmetrical to the detail's axis; heating nonsymmetrical to the detail's axis; heating regardless of the symmetry axis. Thus, such straightening is a thermal treatment, i.e. the processes of thermal impact by certain modes in order to change the structure and properties of material of welded metal structures.

2. The study presents a notation of optimization research into the thermal straightening of wagon metal structures aimed at a decrease of postwelding deformations, as a task of multivariable optimization with restrictions. The parametric and functional restrictions chosen helped form a searching zone of the admissible values.

3. The author described a thermal field with consideration of the heat of phase transition according to the thermal coefficients of temperature, which is reduced to solution of a Stefan problem. The study gives phase transitions for Steel 09G2S, procedure of reduction of a Stefan problem to a thermal conductivity problem with a mobile heating source by arc straightening with 
a gas burner for elements of the center sill and the top cord of an open wagon.

4. It is recommended to use the wedge method for thermal straightening of center sills and top cords (C-like structures) of standard open wagons. The heating zone is formed as an isosceles triangle, the apex of which is directed to further deflection of the beam.

5. Heating zones under the thermal straightening of the center sill and the top cord should be formed symmetrically and simultaneously at both sides. The most rational parameters of the thermal straightening for the center sill are as follows: optimal heating temperature fluctuates in a range from 800 ${ }^{\circ} \mathrm{C}$ to $850^{\circ} \mathrm{C}$, height of the heating triangle - from $100 \mathrm{~mm}$ to $120 \mathrm{~mm}$, width - from $80 \mathrm{~mm}$ to $100 \mathrm{~mm}$; for the top cord: optimal temperature - from 600 ${ }^{\circ} \mathrm{C}$ to $650^{\circ} \mathrm{C}$, height of the heating triangle - from $50 \mathrm{~mm}$ to $90 \mathrm{~mm}$, width from $40 \mathrm{~mm}$ to $80 \mathrm{~mm}$. And the number of heating spots varies in a range from 3 to 5 at each side.

6. The additional diagrams developed should be used for a search of the optimal geometric parameters of heating spots of the center sill and the top cord of universal open wagons according to the initial deformational deflection. For example, the optimal parameters of the center sill at the most popular deflection $100 \mathrm{~mm}$ are: heating temperature $800{ }^{\circ} \mathrm{C}$, height of the heating triangle $\mathrm{h}=107 \mathrm{~mm}$, and width $\mathrm{b}=85 \mathrm{~mm}$. The optimal parameters for the center sill at the most popular deflection $380 \mathrm{~mm}$ are: heating temperature $600{ }^{\circ} \mathrm{C}$, height of the heating triangle $\mathrm{h}=78 \mathrm{~mm}$, and width $\mathrm{b}=$ $65 \mathrm{~mm}$.

7. The study describes the straightening stages for the technologically deformed center sill and the top cord with thermal non-impact procedure realized by internal thermal stressed state. The results of computer modelling for the straightening process are presented as mathematical dependencies. It was mentioned that by analyzing the additional diagrams it is possible to choose sizes of heating zones, and values of heating temperatures; it makes it possible to eliminate deflections emerging under the technological welding process by metal straightening. 


\section{CHAPTER 3 \\ COMPUTATION AND EXPERIMENTAL RESEARCH INTO THERMAL STRAIGHTENING OF WAGON STRUCTURES}

\subsection{Organization of experimental research}

The stages of the computer modelling of thermal straightening and experimental research aimed at determination of efficiency of thermal straightening for metal wagon structures are given in Fig. 3. 1.

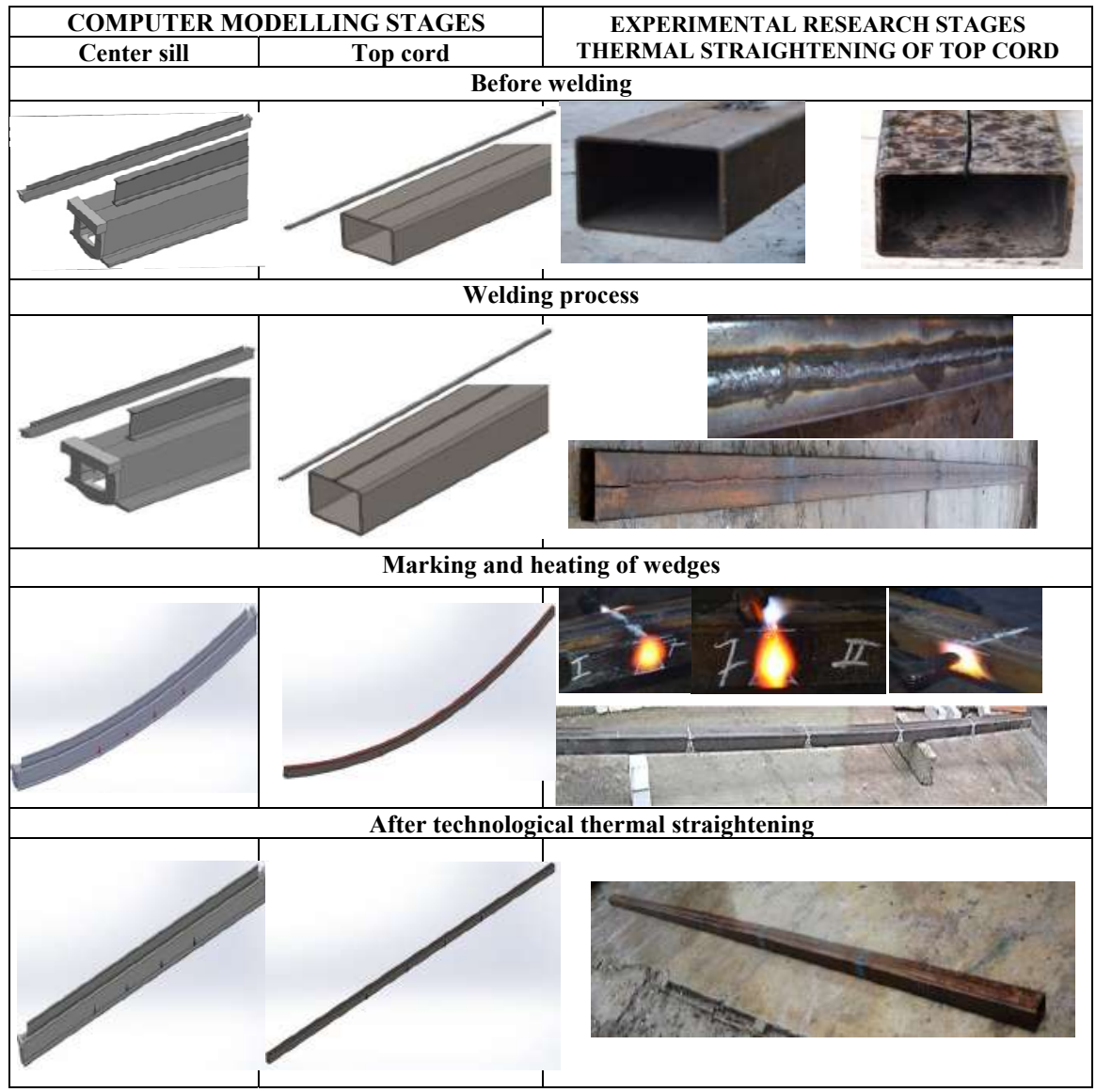

Fig. 3.1. Stages of thermal straightening modelling for computer and experimental research into wagon metal structures 
The experiment was conducted on a full-scale sample of the size (length $\mathrm{x}$ width $\mathrm{x}$ height), which considered structure, technology and material, similar to the real top cord of an open wagon (Fig. 3.2). The experiment demonstrated a $30-\mathrm{mm}$ deflection in the center sill, which was eliminated by heating certain areas on the test model [94].
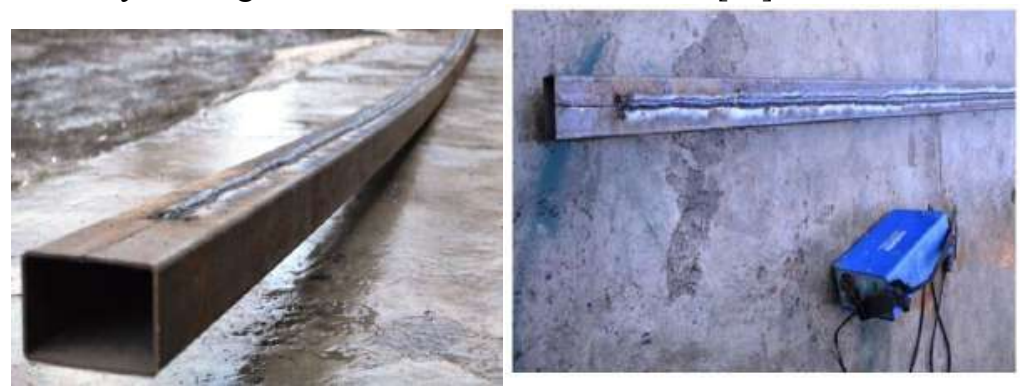

Fig. 3.2. Top cord test sample after technological welding

The methodical stages of the experimental research are [65]:

- welding joint along the sample length with welding equipment;

- measuring the deflection after cooling; and

- determination heating zone sizes (isosceles triangles, called wedges) according to the deflection, their location on the test sample (see Fig. 3.1) and heating temperature.

The experimental research stages are:

- welding joint along the sample length with welding equipment;

- measuring the deflection after cooling;

- determining heating zone sizes (isosceles triangles, called wedges) and heating temperature;

- heating the marked vertical flanges of the wedges (with a gas oxygen flame) until they reach cherry red/red colour in the heating area;

- cooling the test sample after heating all wedges; and

- controlling the deflection elimination, formed during welding, after cooling $[95,96]$.

\subsection{Experimental research into thermal straightening with local heating of wagon metal structures}

This Chapter of the presents the results of the thermal straightening modelling for a test model with the specialized module Cosmos as part of solid modelling computer-aided program SolidWorks $[84,96]$. 
Fig. 3.2 presents a fragment of the test sample model divided into finite elements. Heating was set as additional shrinkage deformations in the beam plane. The elasticity theory (method of shrinkage function) was used in solution of general deformations as a $3 \mathrm{D}$ problem.

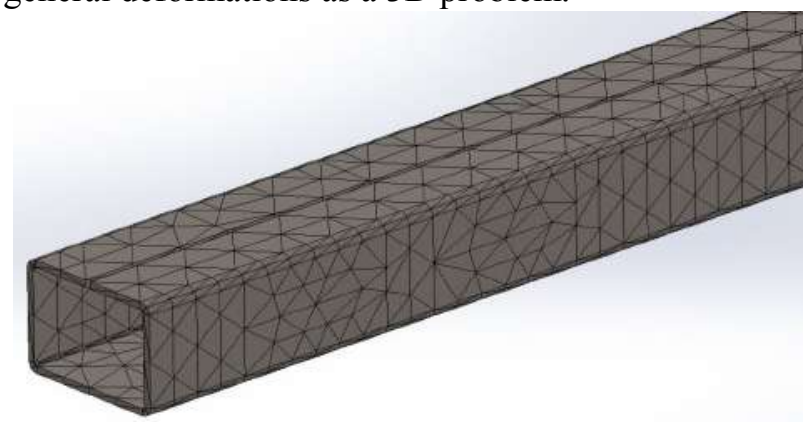

Fig. 3.2. Finite-element model of top cord test sample of open wagon

The method of shrinkage function is an approximation and it does not consider emergence and development of elastic-plastic deformations. Therefore, the designed model cannot be used for determination of a sequence of heating impacts on the general deformation of the sample. In comparison with the general method of thermal plasticity, the method of shrinkage is more advantageous as it gives a possibility to obtain solutions in terms of general deformations of complex spatial structures with a great number of heating sets.

Fig. 3.3. and Fig. 3.4 depict the top cord test sample of an open wagon obtained in SolidWorks software prior to welding (before a welded joint) and after welding (the axle line is not distorted) [88].

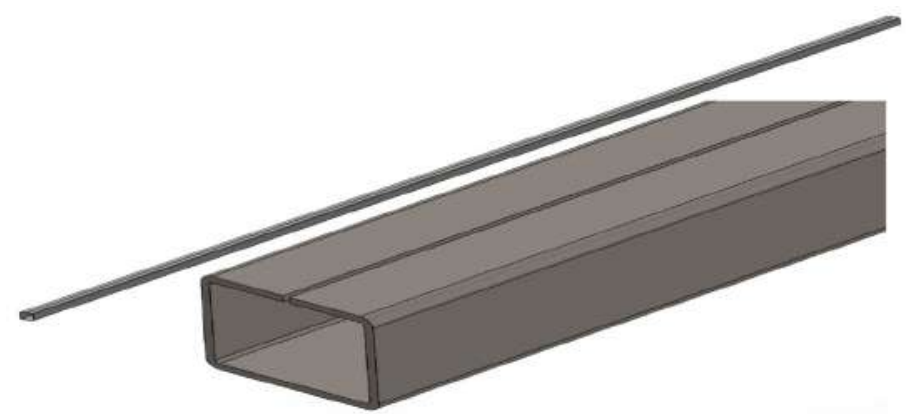

Fig. 3.3. Test sample of top cord without welded joint 


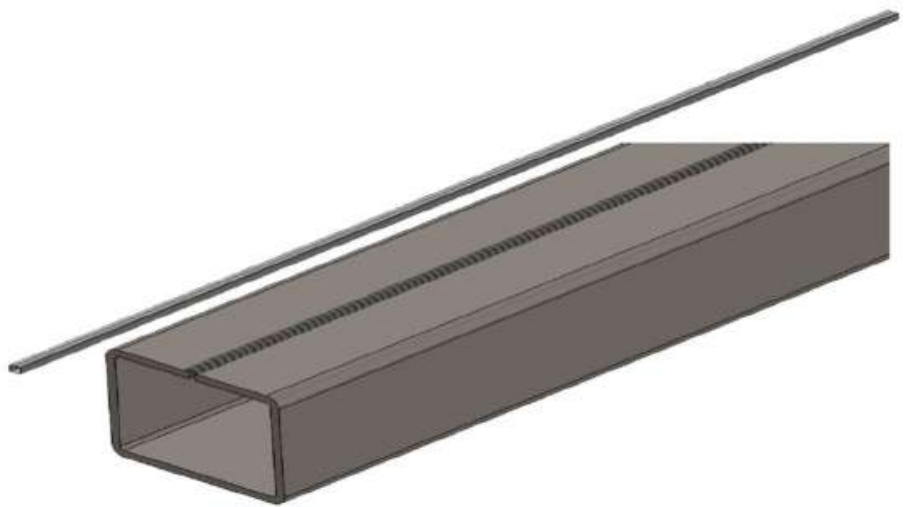

Fig. 3.4. Test sample of top cord with welded joint (axle line is not distorted)

Fig. 3.5 gives the finite-element model of the test sample after a welded joint. As seen from the model, the temperature heating of the sample modelled with special module Cosmos led to distortion of its longitudinal axle, i.e. emergence of a deflection (in this case $300 \mathrm{~mm}$ ). Here we can also see location of heating zones in the form of isosceles triangles.

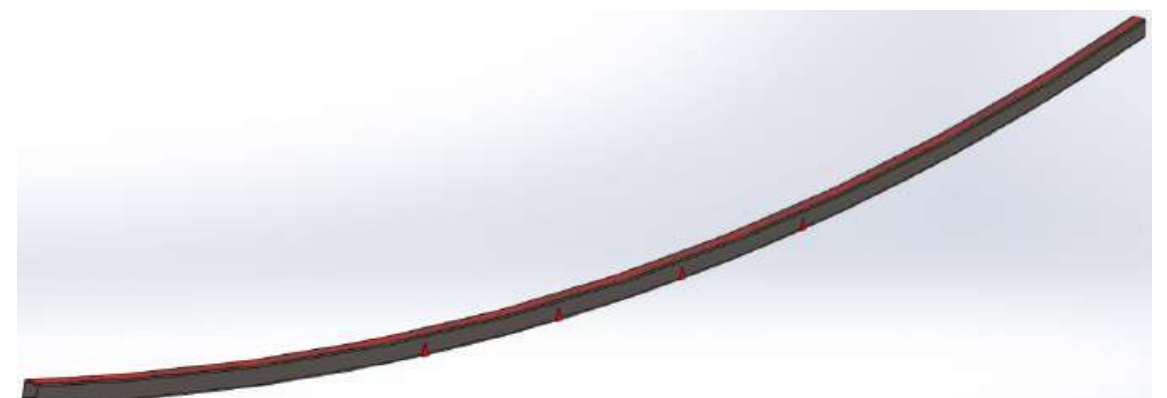

Fig. 3.5. Finite element model of test sample of top cord with location of heating zones

The sizes of heating zones (wedges) and the heating temperatures were used in special module Cosmos for simulating the heating straightening of the test sample. Thus, the heating of the wedges was modelled. Finally, after cooling one can observe elimination of the deflection obtained in technological welding (the axle of the test sample became straight) (see Fig. 3.6) [88]. 


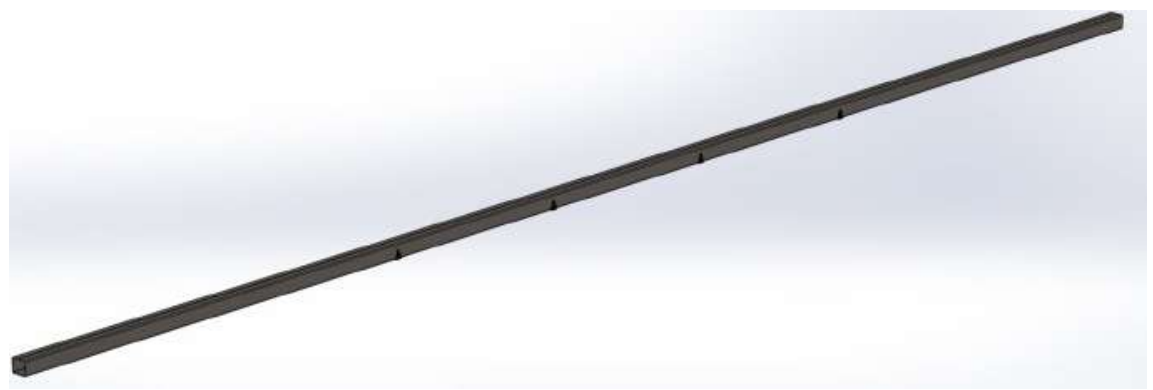

Fig. 3.6. Test sample of top cord after modelling of thermal straightening

The results of the thermal straightening modelling for the test sample of the top cord of an open wagon conducted in SolidWorks were proved by experimental research into the mentioned straightening of a full-scale sample of the top cord by the technique presented above.

Fig. 3.7 gives a full-scale sample of the top cord after technological welding, i.e. putting on a welded joint along the sample. After cooling the longitudinal axle of the sample was distorted thus a deflection was formed. The deflection was measured and accounted for $80 \mathrm{~mm}$ in the center of the beam and $280 \mathrm{~mm}$ at the ends (see Fig. 3.8 and Fig. 3.9).

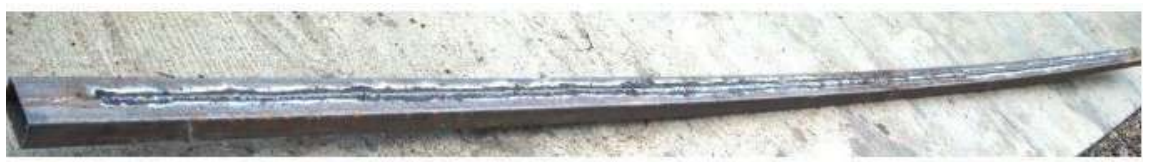

Fig. 3.7. Full-scale sample of top cord of open wagon with welded joint

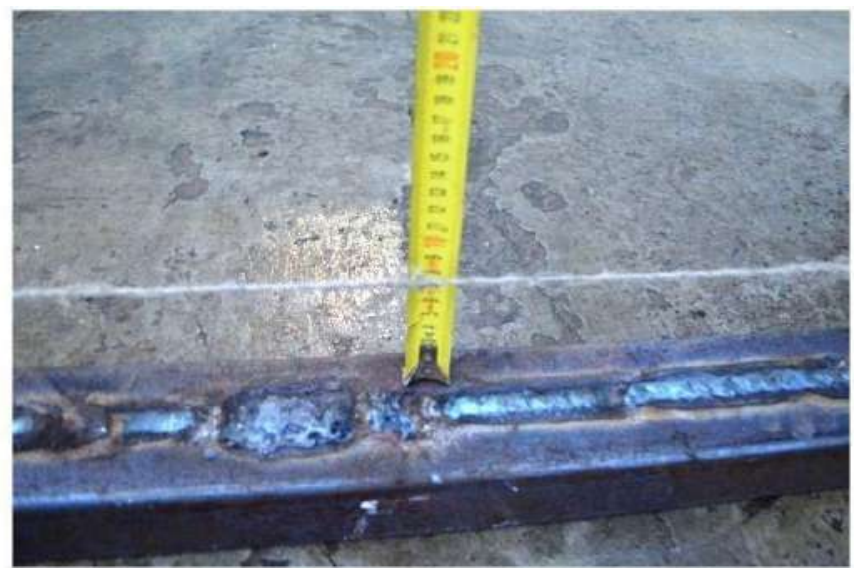

Fig. 3.8. Measurement of deflection in mid-span 


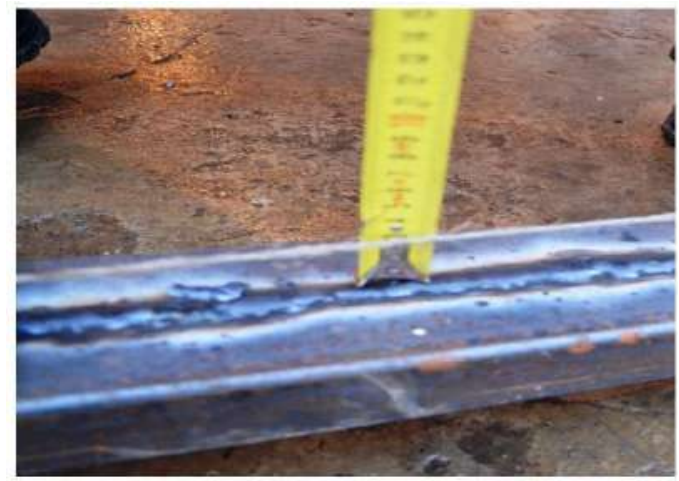

Fig. 3.9. Measurement of deflection at ends

When the deflections were measured, location of heating zones, dimensions and heating temperature were determined. Fig. 3.10 and 3.11 present heating zones in the form of isosceles triangles (wedges).

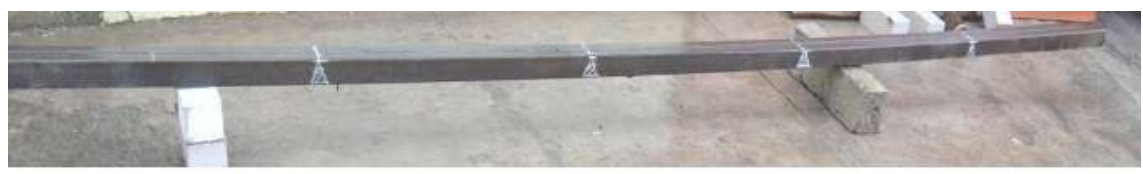

Fig. 3.10. Full-scale sample with marked wedges

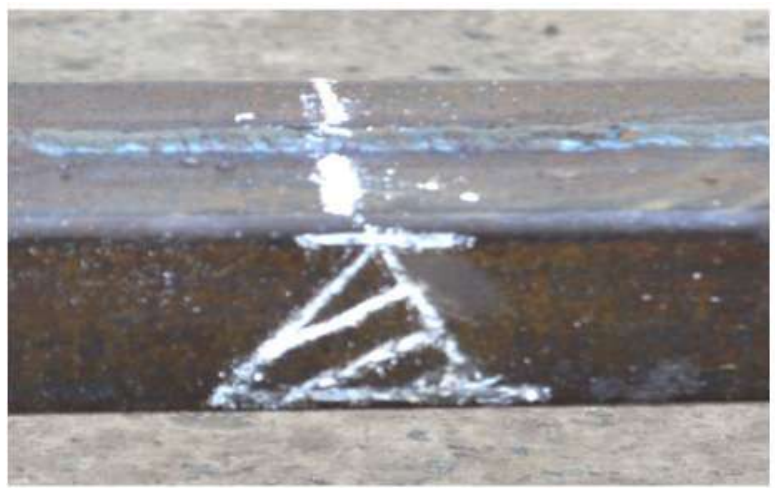

Fig. 3.11. Isosceles triangle (wedge)

After marking wedges on the side (vertical) walls of the full-scale sample with a gas oxygen flame, the wedges were heated to the needed temperature (Fig. 3.12) and measured with a thermo-element (Fig. 3.13). 
The whole heating procedure was conducted with a single oxyacetylene blowpipe, the effective capacity of which (q) changed at various heating sets in a range of 2.5-4.4, the average value being $3200 \mathrm{cal} / \mathrm{s}$.

After the heating of all wedges, the full-scale sample of the top cord was cooled down.
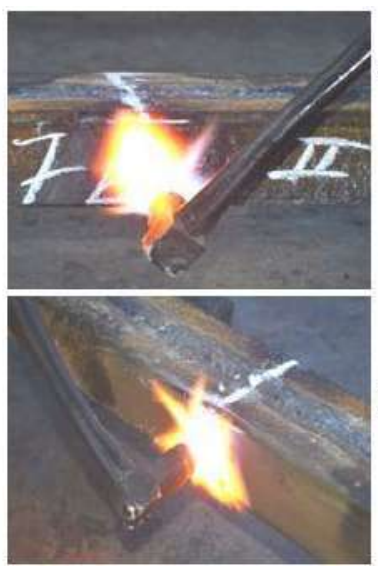

Fig. 3.12. Heating of wedges with gas burner
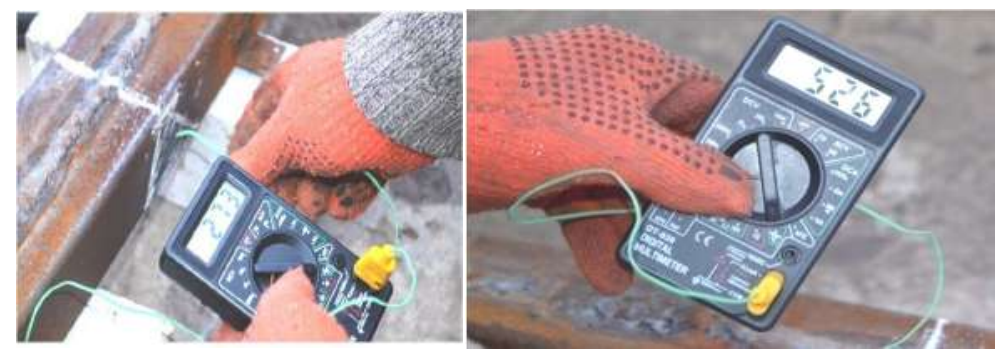

Fig. 3.13. Measurement of temperature under heating wedges

After cooling the distorted axle of the beam was straighten, thus the deflection formed in welding was eliminated (see Fig. 3.14).

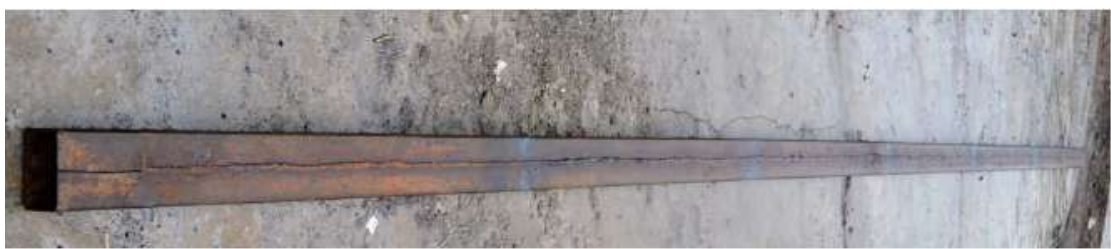

Fig. 3.14. Beam after thermal straightening 


\subsection{Optical microscopy for research into metal structure in heating zone}

After experimental research the author conducted microscopic examination of the metal structure in the heating zone to confirm working capacity of steel 09G2S (the material of the beam) after straightening, and researched into the structural states of the materials of the carrying structures of freight wagons in the zones of thermal impact under thermal straightening.

The microscopic examination was made after straightening at the heating temperature from $450-900^{\circ} \mathrm{C}$ at the microslice with microscope Digital Microskope CELESTRON 44302 B-CGL Deluxe Handheld. A zoom range of the microscope was from 8 to 500 [97].

The preparation of the slices included three stages:

1) mechanical polishing with coated abrasive of grains from $100 \mu \mathrm{m}$ to 5 $\mu \mathrm{m}$ (P150 - P2500 according to ISO-6344);

2) polishing by diamond pasts of the grain fineness $10 / 7,7 / 5$; and

3 ) polishing with felted cloth by adding aqueous slurry of chromic oxide $\mathrm{Cr} 2 \mathrm{O}_{3}$.

The microstructure of the samples was detected with the method of chemical and electrolytic etching. The etching was made with accordance to recommendations $[98,99]$. Nital $\left(4 \% \mathrm{HNO}_{3}\right)$ and saturated solution of picric acid in ethylic alcohol were used to reveal structures of pearlite, bainite and martensite. Etching of the slices was made with cotton wool wads or by sinking them into a tank. The $10 \%$ aqueous solution of chromic anhydride $\mathrm{Cr} 2 \mathrm{O} 3$ and the $10 \%$ aquatic solution of ethanedioit acid (etching stress - 20V) were used for electrodeposited etching. The recommendations presented above were considered in production of the microslice for the research (Fig. 3.15).

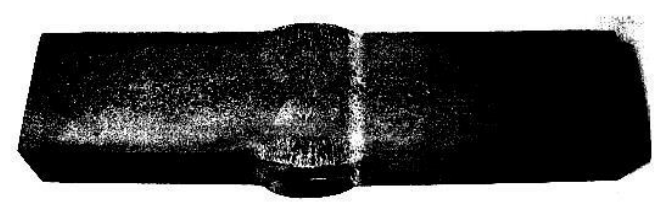

Fig. 3.15. Microslice for research into structural states of materials in zones of temperature impact at thermal straightening

The following observations were made under research into effect of an untreated microslice on changes in non-ferrous inclusions in samples 1 and 2. 
The general number and size of non-ferrous inclusions in comparison with that of the base metal were the same before and after straightening. There were one-dimensional oxides of 2-3 points, single silicate inclusions, and no sulphide inclusions.

The metal of sample 1 was heated. The thermal cycle affected the structural state of steel, which, in its turn, led to changes in the mechanical properties of steel. The most optimal thermal cycle should provide plastic behavior of the base metal after external heating above the line $A_{1}$ (PSK) $\left(725^{\circ} \mathrm{C}\right)$, when austenite was transformed into pearlitic grains, and in some places above line $\mathrm{A} 3(\mathrm{GS})\left(860^{\circ} \mathrm{C}\right)$ it provided short overheating of austenite (Fig. 3.17).

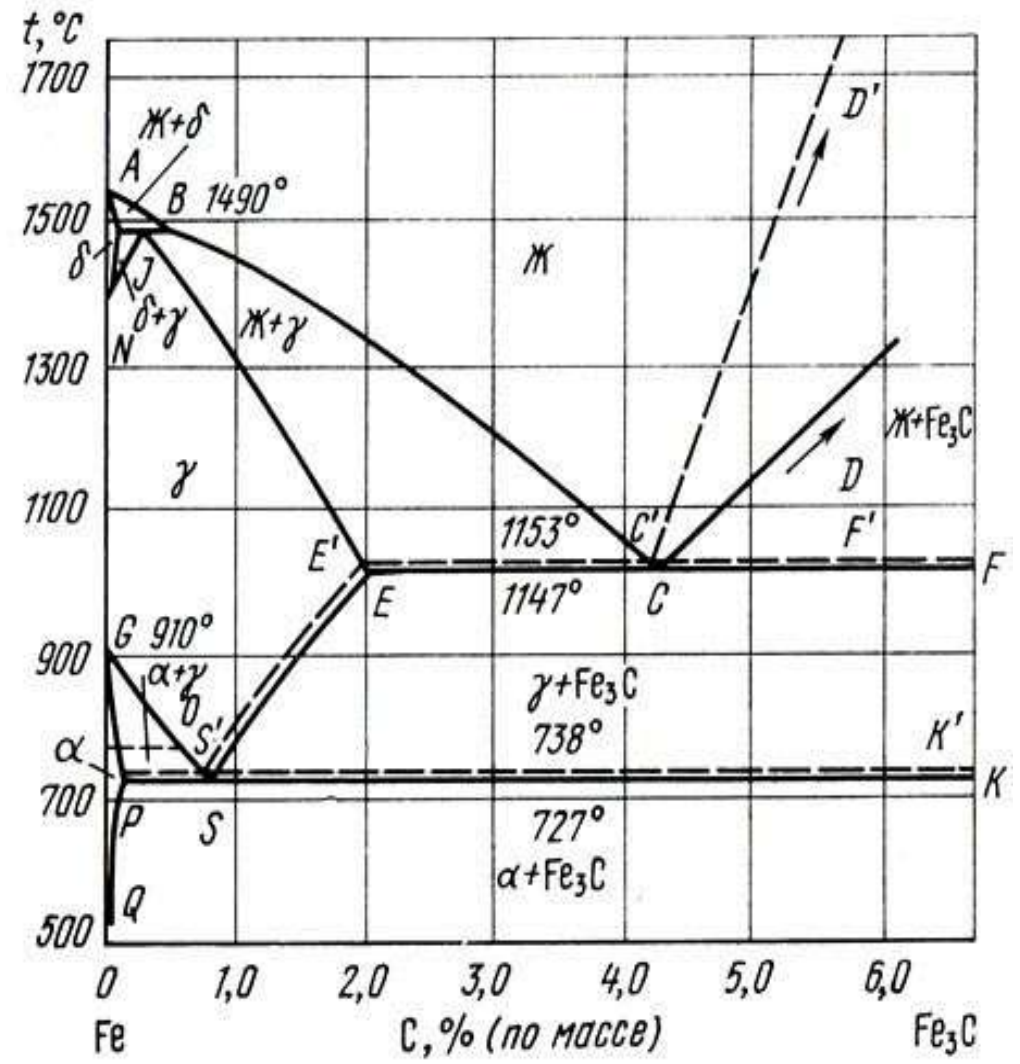

Fig. 3.17. Iron/carbon diagram element 
The structural changes were conditioned by steel polymorphism. The output ferritic-pearlitic or sorbitic steel structure kept stable only up to the transformation point $A_{1}$. A long term effect of the temperature above $A_{3}$ on metal encourages an increase of an austenite grain, and when the grain grows the plastic properties of metal decrease. The metal was heated in a temperature range of $700-900^{\circ} \mathrm{C}$; the structure included ferritic and pearlite grains (Fig. 3.18, b). The ferritic grain was 8 points [99]. The ferrite is presented both as polygonal and acicular components. The polygonal ferrite extended around the former austenite grain filled with acicular ferrite and pearlite. Generally, the structure is coarse with great amount of stress concentrators.

a) before straightening

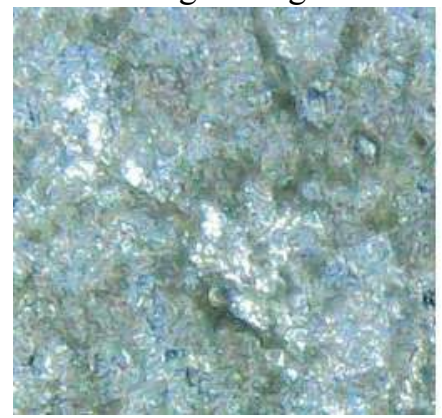

Microstructure of Sample 1

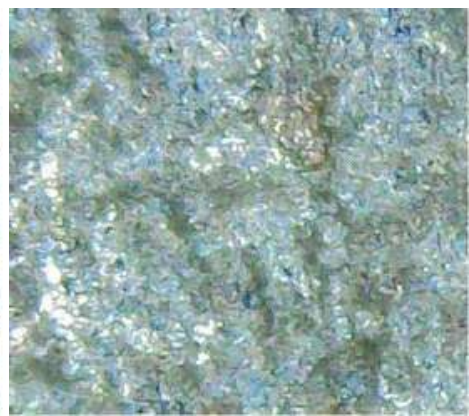

Microstructure of Sample 2

b) after straightening

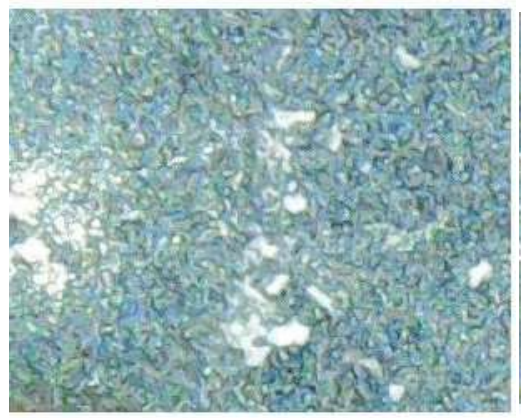

Microstructure of Sample 1

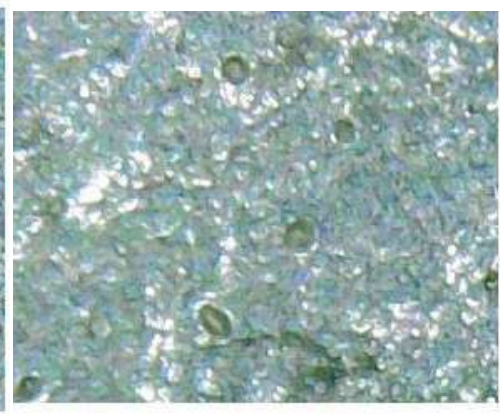

Microstructure of Sample 2

Fig. 3.18. Microstructure of wedge heating zone for straightening Steel 09G2C (x500):

a) before straightening; b) after straightening 
The heating temperature should not exceed the line A3, i.e. the temperature of phase transition end. An increase of the heating temperature by more than $100{ }^{\circ} \mathrm{C}$ above the line $\mathrm{A} 3$ is not recommended, as it generates an intensive growth of the austenite grain. Thus, for Steel 09G2S the optimal heating temperature varies in a range of temperatures $\mathrm{T}_{\text {opt }}=800^{\circ} \mathrm{C}-830^{\circ} \mathrm{C}$ according to study [72]. A small increase in the heating temperature up to $50^{\circ} \mathrm{C}$ can be observed in a zone heated by a flame of a blowpipe. If under straightening a blowpipe moves uniformly across the wedge section a temperature drop is not significant.

The microstructure of Sample 1 is the same after (Fig. 3.18, b) and before (Fig. 3.18) straightening with returning and annulling process inside. The ferrite grain is more balanced in comparison with that in Sample 1, its size is 8-9 points. The acicular component is less coarse in comparison with that of Sample 1 (Fig. 3.17, a) [98]. The metal of Sample 2 before straightening (Fig. 3.18, a) is of the ferrite-pearlite structure which is rolling oriented (Fig. 3.18, a). The grain size of the base metal equals 10 points by the scale.

The results of metal graphical research into the structure of Steel 09G2S at the temperatures (600-450) ${ }^{\circ} \mathrm{C}$ after the $\gamma \rightarrow \alpha$-transformation in the isothermal conditions are given in Fig. 3.19.

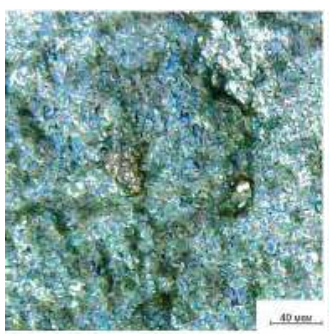

a)

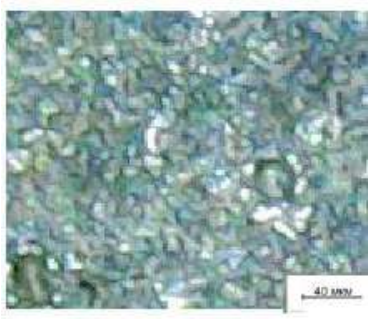

b)

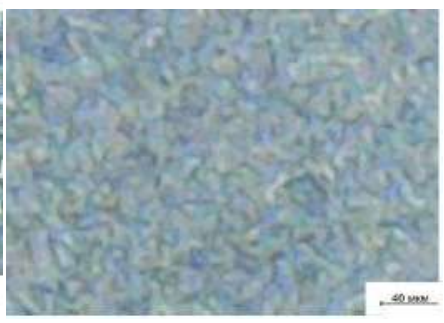

c)

Fig. 3.19. Microstructure of samples of Steel 09G2S after isothermal decomposition under straightening of wedge: a) $500{ }^{\circ} \mathrm{C}$; b) $600{ }^{\circ} \mathrm{C}$; c) $700{ }^{\circ} \mathrm{C}$

The metallographic examination demonstrated that the isothermal transformation at the temperature $600{ }^{\circ} \mathrm{C}$ led to formation of two structural components - globular light and dark ones which etches the martensite-like component of needle-like crystals. Analysis of the light component at high magnification demonstrated that it is ferrite, though non-homogeneous, and composed of ferrite grains of low density of dislocations and equal borders without visual inclusions inside the grains, and also of ferrite with wavy boundaries called the meso-ferrite. 
Electron-microscopic examination of the steel microstructure after the isothermal $\gamma \rightarrow \alpha$-decomposition at $500{ }^{\circ} \mathrm{C}$ demonstrated that after transformation the structure composes of polyhedral ferrite of high density of dislocations and bainite of well-defined grid structure (Fig. 3.18, b). A beinite area of non-grid structure is given in Fig. 3.18, c.

An electron-diffraction pattern of such an area demonstrates two ferrite grids with the axes of the zones (001) $\alpha 1$ and $135 \alpha 2$, and an austenite grid (001) $\gamma$. Reflexes in the electron-diffraction pattern are characterized by strong azimuthal dithering indicating presence of considerable stresses in the structure. The Bain ratio (001) $\gamma \|$ (110) $\alpha$ is kept between ferrite and austenite.

The grid bainite found in the structure was grouped in $\alpha$-phase grid packages; the grid width was 0.1-0.5 $\mu \mathrm{m}$ (Fig. 3.18, b). The package structure of bainite $\alpha$-phase is a feature of low bainite or martencite of low-carbon structural steels.

The research demonstrated that the structure consists of not only grid bainite areas but also wide crystals of $\alpha$-phase with small plate-like particles. The analysis helped to determine that these inclusions inside the crystal were cementite, the image of the structure was obtained in the cementite reflection (102) $\mathrm{Fe}_{3} \mathrm{C}$. Cementite particles in the $\alpha$-phase of bainite was the result of self-tempering of bainite (or martencite) crystals during cooling, and conditioned more intensive etching of a dark structural component revealed in metallographic examination.

The package structure of $\alpha$-phase, inclusions of cementite inside wide crystals of $\alpha$-phase and residual austenite in the structure are specific features of bainite transformation at low temperatures.

A drop of temperature in isothermal transformation of austenite to 500 ${ }^{\circ} \mathrm{C}$ leads to formation of the structure which is a uniform mixture of darker and lighter areas of small sizes and irregular forms. Metallographic examination at possible boundary increases showed that light areas had a relief related to well-defined internal fragment structure of bainite ferrite.

It was revealed that about $50 \%$ of the structure is taken by beinite areas of subgrain structure - $\alpha$-phase crystals divided into fragments and disoriented relative to each other by the angle $5-7^{\circ}$. The other half of the structure is of standard grid nature with thin residual austenite layers on the boundaries. The bainite areas of subgrain and grid structures are mixed.

Metallographic observation did not detect acicular structure in a mixture of both morphological types of bainite; in publications it is often called the grain bainite or the granular bainite. It was mentioned that such a 
bainite form is mostly typical at continuous cooling, and very rare at isothermal conditions. It was formed due to fluctuation re-distribution of carbon and alloyed element between $\alpha$ - and $\gamma$ - phases during the isothermal $\gamma$ $\rightarrow \alpha$-transformation. Formation of first portions of $\alpha$-phase goes along with transfer of carbon to austnite, which at isotermic aging is transformed to the so-called the MA (martensite-austensite) component, which is the product of transformation of enriched carbon to austensite. Such a location of austenite (thin layers in the MA component) is advantageous.

After transformation at $500^{\circ} \mathrm{C}$ bainite of granular morphology is the basic structure. The research into the thin structure showed that the bainite of granular morphology is actually a mixture of some morphological components. Thus, for example, the structure has ferrite areas of polyhedral form with high density of dislocations with layers of residual austenite on the boundaries. Besides there develop small portions of acicular ferrite. However the basic morphological type is the bainite of sub-granular structure (fragments of different sizes, though not exceeding $0.5 \mu \mathrm{m}$, and the disorientation angle to each other is $5-7^{\circ}$ ). On the basis of literature values and results from earlier research it is possible to state that domination of bainite of developed sub-grain structure in steel positively affects the mechanical properties of the steel under study.

\subsection{Determination of mechanical characteristics in heating} zone

The mechanical characteristics of a welded joint were determined in accordance with requirements [100-103]. The samples were cut out of the testing specimens of a welded joint and out of the testing samples after straightening according to the diagram presented in Fig. 3.20 (testing samples were cut for production of plane samples to study the properties of the joint metal and the base metal of a wedge after straightening).

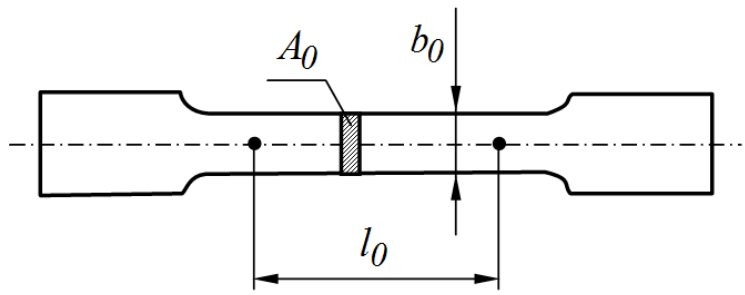

Fig. 3.20. Diagram of testing flat bar to study materials for tension 
The samples were tested for torsion at $500^{\circ} \mathrm{C}, 600^{\circ} \mathrm{C}, 700^{\circ} \mathrm{C}, 800^{\circ} \mathrm{C}$ and the force to $50 \mathrm{kN}$ with the universal testing machine $2054 \mathrm{P}-5$ (Fig. $3.21)$.
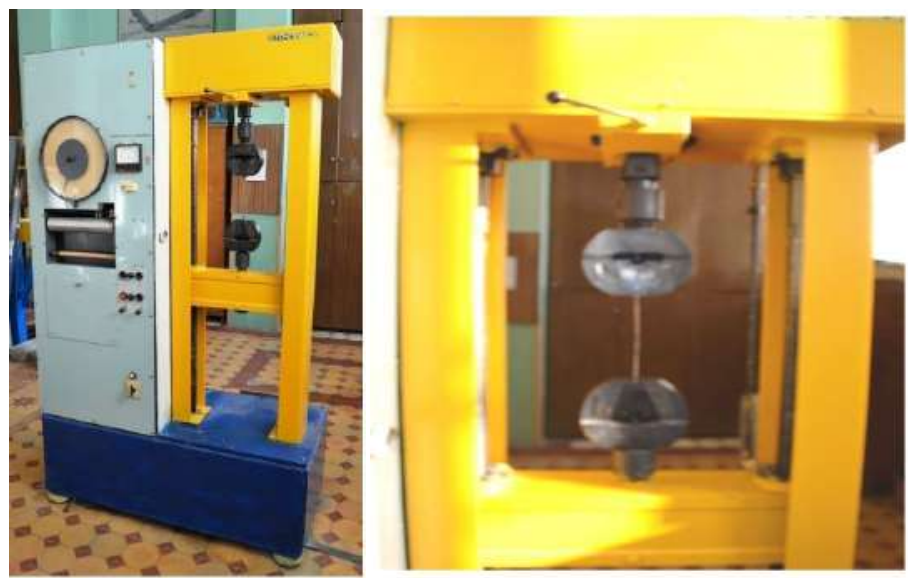

Fig. 3.21. Universal machine P-5 for static torsion testing

The technical characteristics of the equipment (machine 2054 P-5):

The greatest boundary load $-50 \mathrm{kN}$.

The number of force sensors -4 .

The displacement speed of an active grab of the machine 2054 P-5 $100 \mathrm{~mm} / \mathrm{s}$.

The measurement range of an active grab speed:

- range I - $1 \mathrm{~mm} / \mathrm{min}-10 \mathrm{~mm} / \mathrm{min}$;

- range II - $10 \mathrm{~mm} / \mathrm{min}-100 \mathrm{~mm} / \mathrm{min}$.

The admissible boundary for a relative measurement error of the speed at the working active grab is $\pm 5 \%$.

The idle run speed of an active grab of the machine 2054 P-5 should be no less than $200 \mathrm{~mm} / \mathrm{min}$.

The power consumption - no more than $1.2 \mathrm{~kW}$.

The power supply of the machine $2054 \mathrm{P}-5-380 \mathrm{~V}, 50 \mathrm{~Hz}$.

The dimensions $-2200 \times 850 \times 1335 \mathrm{~mm}$.

The mass $-650 \mathrm{~kg}$.

After testing on the samples the author obtained torsion diagrams. According to [101] at least two samples were used for each testing. On the basis of these diagrams and using standard techniques [101-105] the author determined the following mechanical characteristics: yield boundary $\sigma_{T}$, 
temporary resistance $\sigma_{u t}$, percentage extension of fracture $\delta$ and transverse contraction $\psi$. The test results were estimated according to study [101]. At the same time a self-recorder was connected to the machine and drew the socalled a Prandtl diagram (Fig. 3.22).

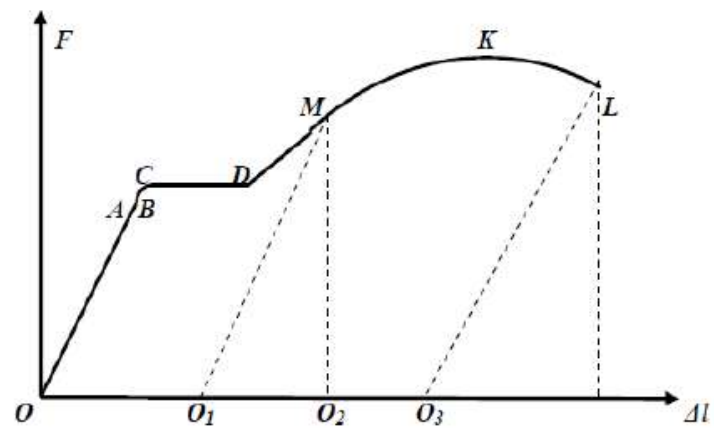

Fig. 3.22. Tensile diagram for plastic material $(\Delta 1, F)$

Tensile diagrams for the top cord at the fusing temperatures 500 $800^{\circ} \mathrm{C}$ (Fig. 3.23-3.26).

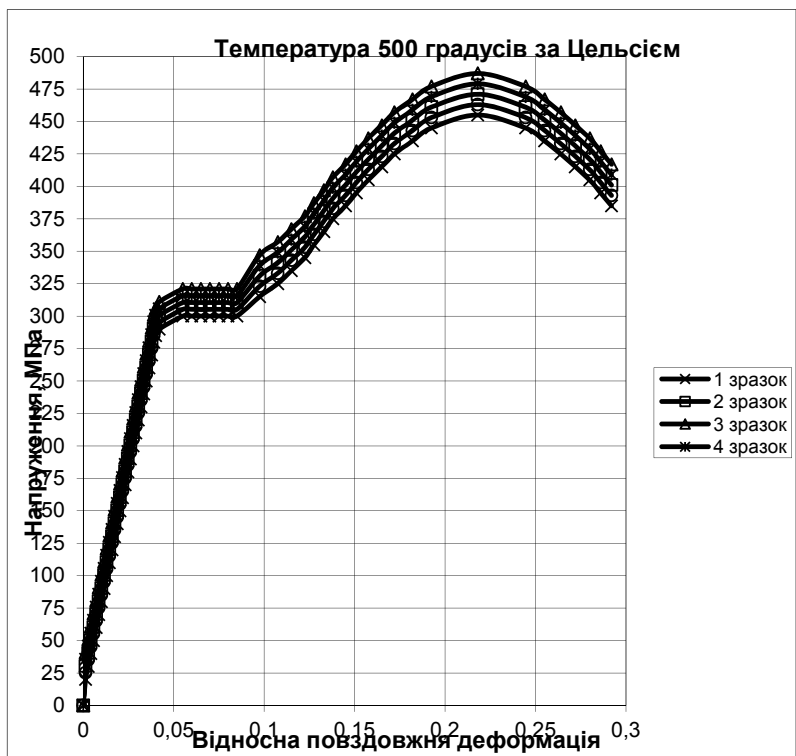

Fig. 3.23. Tensile diagram at $500{ }^{\circ} \mathrm{C}$ 


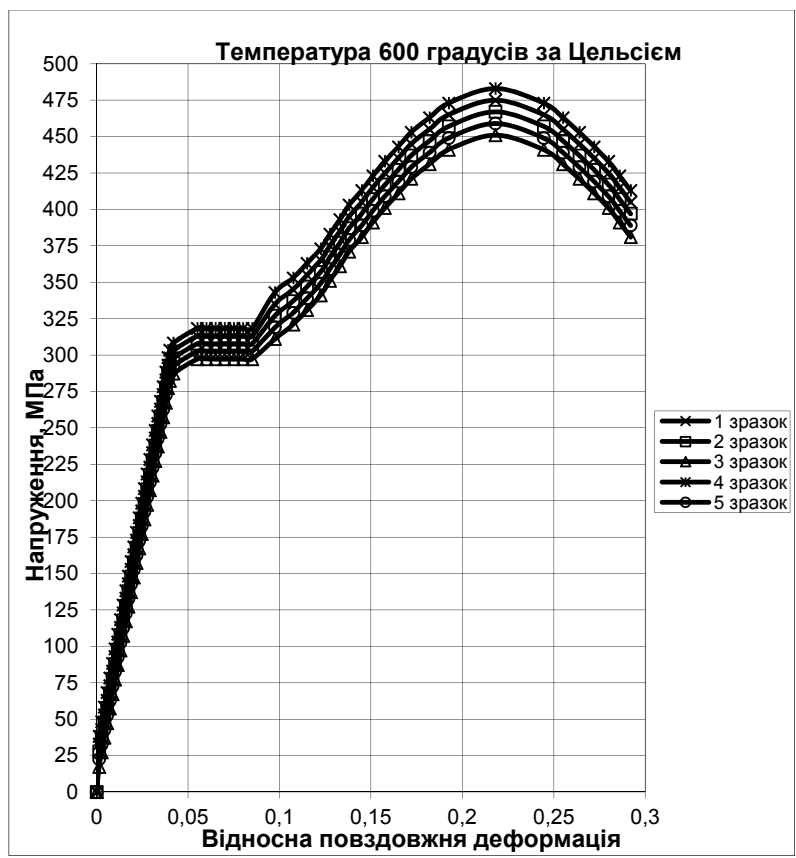

Fig. 3.24. Tensile diagram at $600{ }^{\circ} \mathrm{C}$

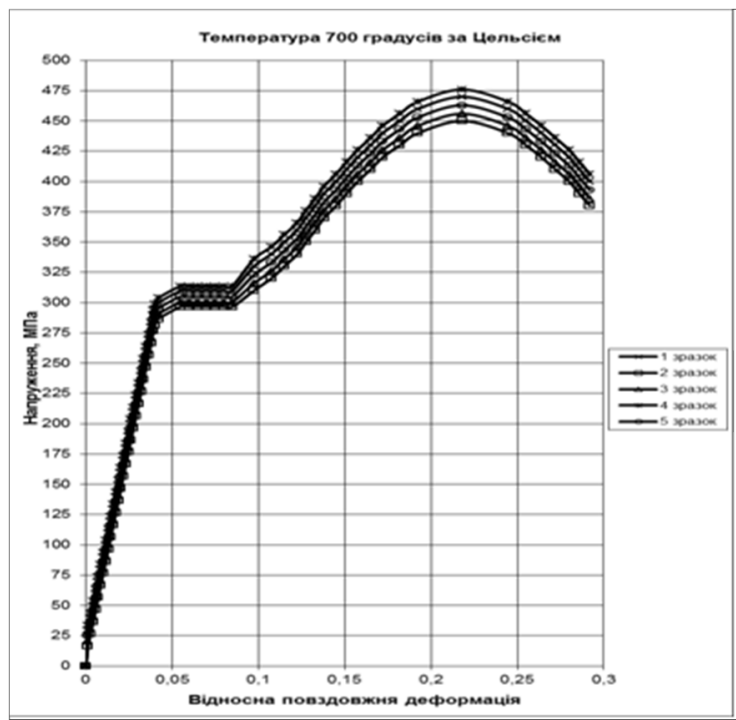

Fig. 3.25. Tensile diagram at $700{ }^{\circ} \mathrm{C}$ 


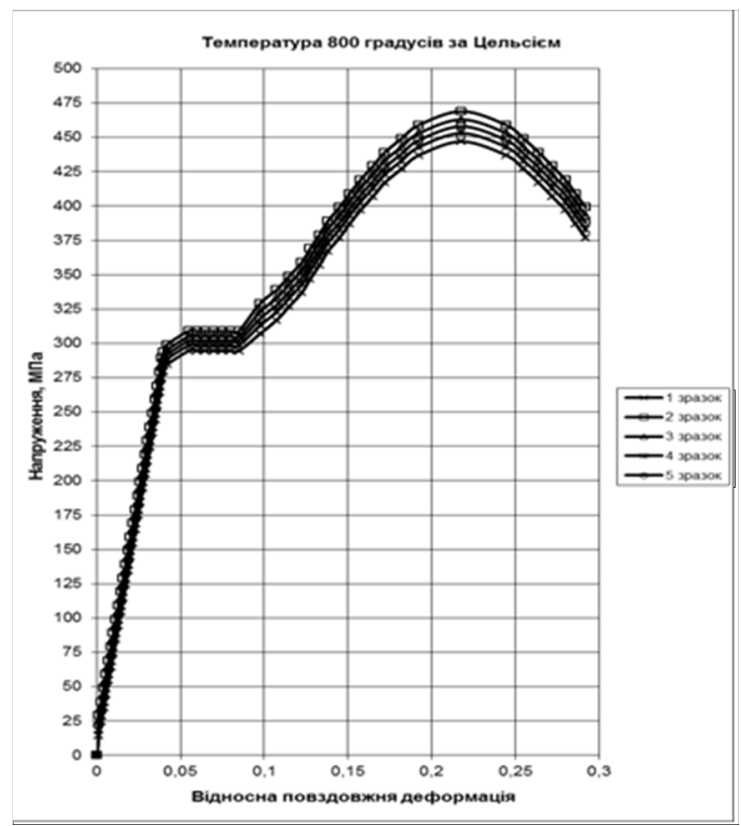

Fig. 3.26. Tensile diagram at $800{ }^{\circ} \mathrm{C}$

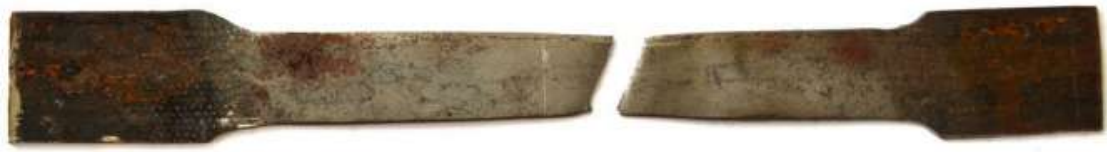

Fig. 3.27. Sample of top cord tested at $600{ }^{\circ} \mathrm{C}$

Tensile diagrams for the center sill at the fusing temperatures 500-800 ${ }^{\circ} \mathrm{C}$ are given in Fig. 3.28-3.31. 


$$
\frac{r}{r}
$$




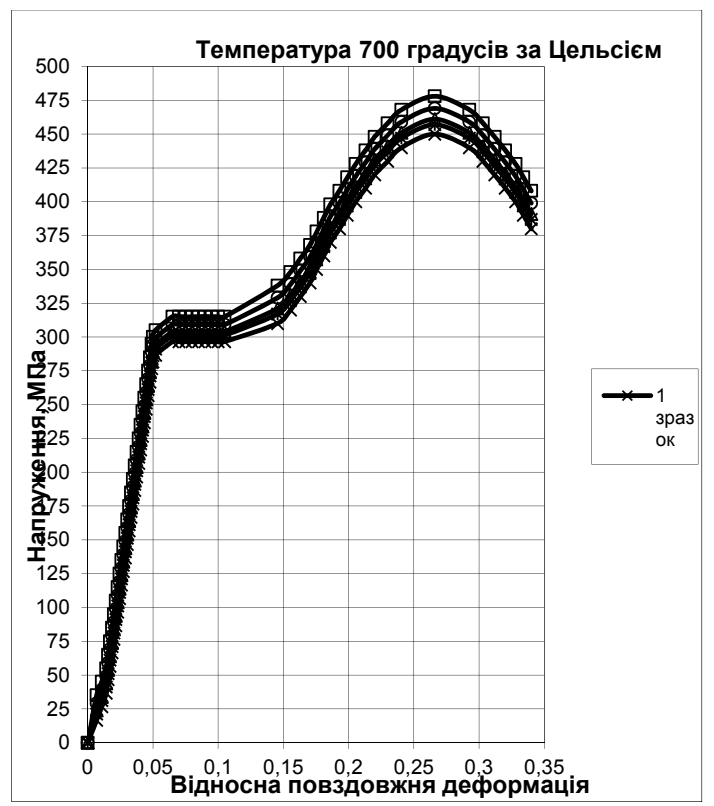

Fig. 3.30. Tensile diagram at $700{ }^{\circ} \mathrm{C}$

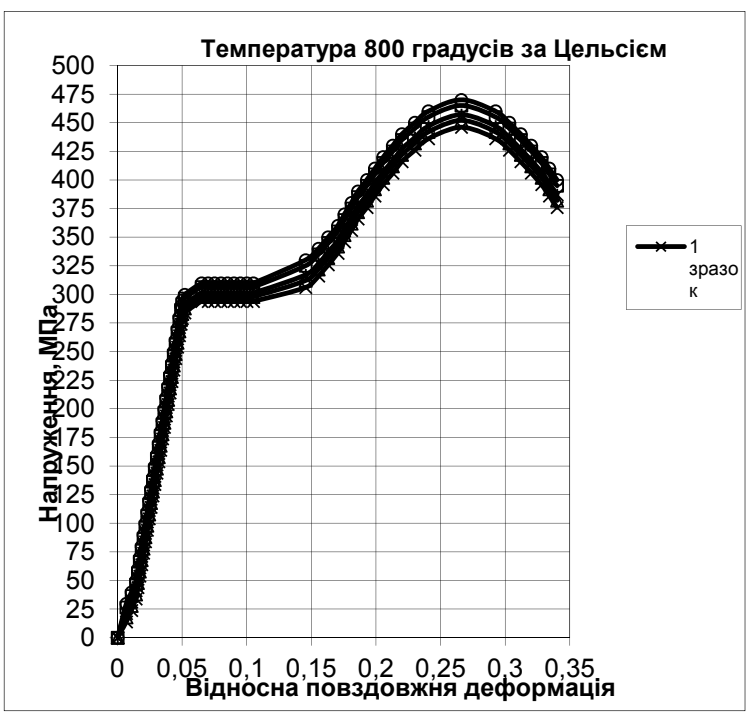

Fig. 3.31. Tensile diagram at $800{ }^{\circ} \mathrm{C}$ 
The mechanical characteristics of metal in a heating zone obtained after straightening of the full-scale test sample of wagon metal structure confirmed their insignificant deviations from those defined before the straightening, i.e. decrease of the yielding boundary by $6-7.5 \%$. It is grounded by a need to ensure a certain level of the properties of material.

Measurements of micro-hardness of structural components

The micro-hardness of triangles after straightening was measured by depth on metallographic slices with the micro-hardness tester PMT-3 with accordance to GOST 9450-76. The micro-slices were produced by the technology described above. The loading by the indenter was 0.5 and $1 \mathrm{~N}$ according to the structural components under measurement. A diamond pyramid with an angle of convergence $45^{\circ}$ was used as an indenter. Other values of micro-hardness were measured by the diagonal of the impression with the electronic microscope REM-106I, thus avoiding errors in determination of the length by optical measuring method, and re-calculation of the values obtained by GOST 9450-76. An insignificant deflection from ones determined before straightening was a hardness decrease by $8 \%$.

\subsection{Cost-benefit analysis of improved technology implementation for production and maintenance of freight wagons}

This Chapter presents the cost-benefit evaluation obtained due to the author's recommendations. As far as the techniques proposed have not realized yet, there is no possibility to reach absolute accuracy of the results. The cost-benefit evaluation uses the factor of risk and uncertainty (in percent). Thus, the risk is considered as the result of unfavourable solution when situation can be estimated by a previous year. The author used the method of design factor correction so that to consider the factor of risk and uncertainty; this factor is a lower number of open wagons per year. The risk factor was taken $3 \%$ by expert estimation.

The feasibility estimation of implementation is determined on the basis of the modern calculation techniques "Methods for determination of economic efficiency of research, development and production implementation and Procedure and estimation criteria of economic efficiency for investment proposals and projects" [106-109] by comparing costs of cold and thermal straightening.

The basic characteristics of the general economic efficiency, both nationally and in terms of the railway transport, are the net present value (integral economic effect) and the pay-back period. The net present value or 
integral effect is the sum of current effects in the whole accounting period as presented before a start year.

The net present value (profit) is defined by the formula

$$
\text { ЧДД }=\sum_{t=0}^{T}\left(R_{t}-3_{t}\right) \frac{1}{(1+d)^{t}}=\sum_{t=0}^{T} \frac{P_{t}}{(1+d)^{t}} \text {, }
$$

where NPV - net present value;

$\mathrm{R}_{\mathrm{t}}$ - economic effect, million hrn.

$3_{t}-$ capital investments, million hrn.

$\mathrm{t}$ - innovation and investment project period;

$P_{t}-$ net cash flow for period $\mathrm{t}$;

$\mathrm{d}$ - rate of discounting (in national currency 0.17 for August, $1^{\text {st }} 2018$ by National Bank of Ukraine);

Net cash flow (NCF) consists of annual values of cash money which is the difference between inflow and outflow

$$
P_{t_{i}}=\Pi_{t_{i}}-Q_{t_{i}}
$$

where $P_{t_{i}}$ - net cash flow in $t_{i}$ project period;

$\Pi_{t_{i}}-$ incoming payment in this period;

$Q_{t_{i}}$ - expenditures in this period.

The integral net flow;

$$
P_{t}=\sum_{t=0}^{T}\left(P_{t}-Q_{t}\right)
$$

Discounting of cash flows starts at the moment (time) of beginning of the project.

Asynchronical expenditures must be given by one for all time moments; therefore, the reduction factor $\alpha_{t}$ is used

$$
\dot{\alpha}_{\mathrm{t}}=\left(1+\mathrm{E}_{\mathrm{H}}\right)^{\mathrm{t}},
$$

where $E_{n}$ - reduction normative for asynchronical expenditures and results, numerically equals the profit-to-investment ratio $\left(\mathrm{E}_{\mathrm{n}}=0.2\right)$; 
$\mathrm{t}$ - number of years, which detaches expenditures and results of a specific year from those of an accounting year;

In order to define spending of money, let us calculate the full self-cost and labour input of the following works:

- cold straightening of the center sill

- cold straightening of the top cord

- thermal straightening of the center sill

- thermal straightening of the top cord

Costs of cold straightening

Capital investment calculation

Calculation of capital investments for cold straightening of freight wagon elements

Capital investments are one-time spending for technical re-equipment of the fixed-capital assets. While designing the technical re-equipment it is sufficient to calculate additional capital investments for a progressive variant. The total investments $(\mathrm{K})$ for cold straightening are defined by the formula

$$
\kappa=К_{\text {ОБ }}+K_{\mathrm{MP}}+K_{\mathrm{TP}}+\kappa_{\Pi и}+K_{\Pi Р}
$$

where КоБ - costs of modernization (acquisition) of the basic production equipment, million hrn;

$K_{M P}-$ costs of installation of basic equipment requiring assembly operations, tsd hrn.

$\mathrm{K}_{\mathrm{TP}}$ - transportation costs, tsd hrn.

Кпи - costs of production stock and small-scale mechanization equipment of more than three years of service, tsd hrn.

$\mathrm{K}_{\Pi \mathrm{P}}-$ other works and costs, tsd hrn.

Calculation of capital investments for cold straightening of freight wagon elements

The approach proposed for thermal straightening does not require any capital investments. The thermal straightening requires the equipment used for wagon production.

Calculation of salary expenditure for straightening of 100 wagons.

Calculation of salary expenditure for cold straightening.

The self-cost of cold straightening for a freight wagon is calculated by the formula

$$
C_{P}=B_{C P}+B_{O}+\left(B_{C P}+B_{O}\right) \cdot \varepsilon,
$$


where $B_{C P}$ - salary expenditure which includes costs of press straightening (requires a $2^{\text {nd }}$ category metal worker for rolling stock), hrn;

$B_{O}-$ salary expenditures including salary of team manager, hrn;

$\varepsilon$ - factor which considers social expenses, $\varepsilon=0.385$.

Wage expenditures for a 4-categogy metal worker of rolling stock are calculated by the formula

$$
B_{C P}=(1+\alpha+\beta) \cdot T_{C P} \cdot E_{\text {ГTСC }},
$$

where $T_{C P}$ - normative labour intensity of cold straightening operations for center sill by cold method, $T_{C P}=5.6$ persons/hour [110];

$E_{\text {ITCC }}$ - hourly wage rate of a 4-category rolling stock repairman, $E_{\text {ITCC }}=$ $22.36 \mathrm{hrn} /$ year;

${ }^{\alpha}$ - factor considering an additional salary, ${ }^{\alpha}=0.1$;

$\beta$ - factor considering bonus payment, long service benefit and others, $\beta=$ 0.35 .

$$
B_{C P}=(1+0,1+0,35) \cdot 25.15 \cdot 22.36=815.6 \mathrm{hrn}
$$

Wage expenses including those for a cold straightening press are calculated by the formula

$$
B_{b}=(1+\alpha+\beta) \cdot T_{O} \cdot E_{b},
$$

where $T_{O}-$ specified labour intensity, ${ }^{T_{O}}=8.28$ persons/hour [110];

$E_{\text {ITCO }}$ - foreman's hourly tariff wage, $E_{\text {ГTCO }}=45.93 \mathrm{hrn} / \mathrm{hour}$.

$$
B_{O}=(1+0,1+0,35) \cdot 8,28 \cdot 45,93=551.51 \mathrm{hrn}
$$

Thus, expenses for cold straightening of a wagon totals

$$
B_{X I I}=815.6+551.51=1367.11 \mathrm{hrn} .=1.367 \mathrm{tsd} \mathrm{hrn} \text {. }
$$

Wage expenses for two 4-category rolling stock repairmen for thermal straightening for a wagon are

$$
B_{T I I}=2 *(1+0,1+0,35) \cdot 10.6 \cdot 22.636=0.347 \text { tsd hrn. }
$$

Determination of electricity costs for cold straightening

Electricity cost, as part of the material expenses in terms of direct expenditures in wagon production, must be connected only with technological requirements, i.e. electricity for a press for cold straightening.

$$
\mathrm{C}_{\ni}=Ц_{\ni} \times \mathrm{W}_{\text {сил }}
$$


where $Ц_{\ni}$ - price for $1 \mathrm{~kW} / \mathrm{h}$ (for enterprises of Ukrzaliznytsia it is 2.12 hrn.)

$$
\mathrm{W}_{\text {сил }}=\frac{N \times T_{\text {дйсс. }} \times m \times K_{1}+K_{2}}{K_{3} \times \eta},
$$

where $\mathrm{N}$ - installed equipment capacity, for the straightening equipment the technical characteristics is taken according to http://ukrsk.com.ua/ (press for center sill $-12.5 \mathrm{~kW}$ and for pneumatic unit $2-7.3 \mathrm{~kW})$

$\mathrm{T}_{\text {дійсн }}$ - present (calculation) annual fond of equipment hours at 40-hour working week (for $2017 \mathrm{~T}_{\text {дейст }}=1986$ );

$\mathrm{K}_{1}$ - time load factor of equipment, $\mathrm{K}_{1}=0.7-0.8$

$\mathrm{K}_{2}-$ demand factor, $\mathrm{K}_{2}=0.6-0.75$;

$\mathrm{K}_{3}$ - electric line loss factor, $\mathrm{K}_{3}=0.96$;

$\mathrm{m}$ - number of equipment shifts;

$\eta$ - efficiency of electric motors; $\eta=0.85-0.88$

$$
\begin{aligned}
& \mathrm{W}_{\text {сил (ХБ) }}= \frac{12.5 \times 1986 \times 0.7 \times(0.85+0.7)}{0.96 \times 0.86}=32538, \mathrm{kWh} * \text { year } \\
& \mathrm{C}_{\ni}=2,12 * 32538=68,981 \mathrm{tsd} . \mathrm{hrn} . \\
& \mathrm{W}_{\text {сил(ХБ) }}=\frac{7.3 \times 1986 \times 0.7 \times(0.85+0.7)}{0.96 \times 0.86}=26882.6, \mathrm{kWh} * \text { year } \\
& \mathrm{C}_{\ni}=2,12 * 26882=56,991 \mathrm{tsd} . \mathrm{hrn} .
\end{aligned}
$$

The total electricity costs for cold straightening per 100 wagons

$$
\mathrm{C}_{\text {заг.э }}=68.981+56.991=125.972 \text { тис. гр }=0.125 \mathrm{~m} \mathrm{hrn} \text {. }
$$

The self-cost of cold straightening per wagon is

$$
\mathrm{C}_{\text {схп }}=1.25+1.36711=2.62 \mathrm{tsd} \text { hrn. }
$$

Determination of expenses for thermal straightening per wagon

$$
\mathrm{C}_{\text {г }}=Ц_{\ni} \times \mathrm{W}_{\text {сил }}
$$

where $Ц_{\ni}-$ price of $1 \mathrm{~m}^{3}$ of propane/butane mix (for enterprises of Ukrzaliznytsia it is $15.12 \mathrm{hrn}$.)

$$
\mathrm{C}_{\ni}=15.12 * 50=0.756 \text { tsd hrn. }
$$

The thermal straightening cost per wagon

$$
\mathrm{C}_{\text {схп }}=0.756+0.347=1.103 \text { tsd.hrn. }
$$

The calculation results are presented in Table 3.1 


\begin{tabular}{|c|c|c|c|c|c|c|c|}
\hline$\widehat{\tilde{\tilde{D}}}$ & $=$ & $\underset{\mathrm{S}}{\mathrm{i}}$ & స్ & & $\stackrel{\varrho}{\stackrel{\overbrace{}}{ت}}$ & $\begin{array}{l}\hat{\infty} \\
\stackrel{\infty}{0} \\
\vdots\end{array}$ & $\stackrel{m}{\varrho}$ \\
\hline 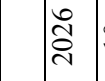 & 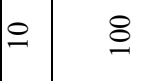 & $\underset{\mathrm{S}}{\mathrm{i}}$ & స్ & ' & $\stackrel{\Re}{=}$ & & $\stackrel{m}{\varrho}$ \\
\hline थิं & $\sigma$ & $\underset{\mathrm{S}}{\mathrm{i}}$ & ్ֻర & & $\stackrel{\overbrace{}}{\stackrel{\overbrace{}}{ت}}$ & & $\stackrel{?}{\varrho}$ \\
\hline ठ্ণ & $\infty$ & $\underset{\mathrm{i}}{\mathrm{i}}$ & ర్ & & $\stackrel{\Re}{=}$ & & $\stackrel{?}{\ominus}$ \\
\hline 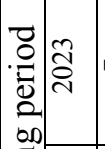 & r & $\begin{array}{l}\text { S. } \\
\text { in }\end{array}$ & ర్ల & , & $\stackrel{\Re}{\varrho}$ & & $\stackrel{?}{\ominus}$ \\
\hline 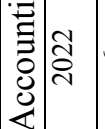 & 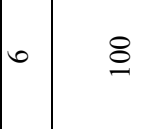 & $\underset{\mathrm{i}}{\mathrm{i}}$ & ర్ర & & $\stackrel{\varrho}{\varrho}$ & & $\stackrel{m}{\ominus}$ \\
\hline$\overline{\overrightarrow{\tilde{C}}}$ & $\stackrel{8}{\circ}$ & $\underset{\text { Ș }}{\text { i }}$ & ర్లి & ' & $\stackrel{\overbrace{}}{\stackrel{\overbrace{}}{:}}$ & & $\stackrel{m}{\varrho}$ \\
\hline ते & 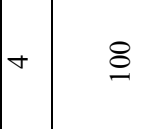 & $\underset{\mathrm{i}}{\mathrm{i}}$ & ర్ర & & $\stackrel{\overbrace{}}{\varrho}$ & & 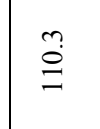 \\
\hline 亏ें & m & $\underset{\text { Ș }}{\text { i }}$ & స్ & & $\stackrel{\overbrace{}}{\stackrel{\overbrace{}}{:}}$ & & 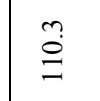 \\
\hline 交 & $\sim$ & 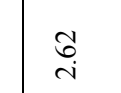 & స్ర & $\hat{\imath}$ & 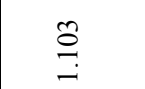 & & $\stackrel{?}{\varrho}$ \\
\hline 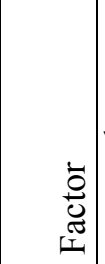 & 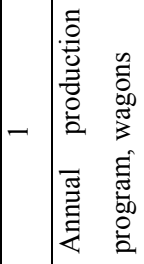 & 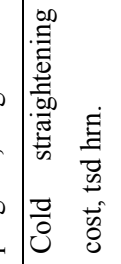 & 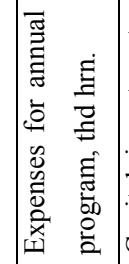 & 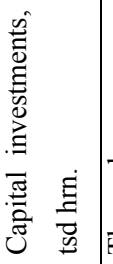 & 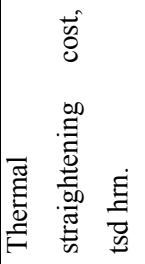 & 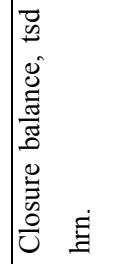 & 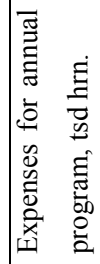 \\
\hline
\end{tabular}




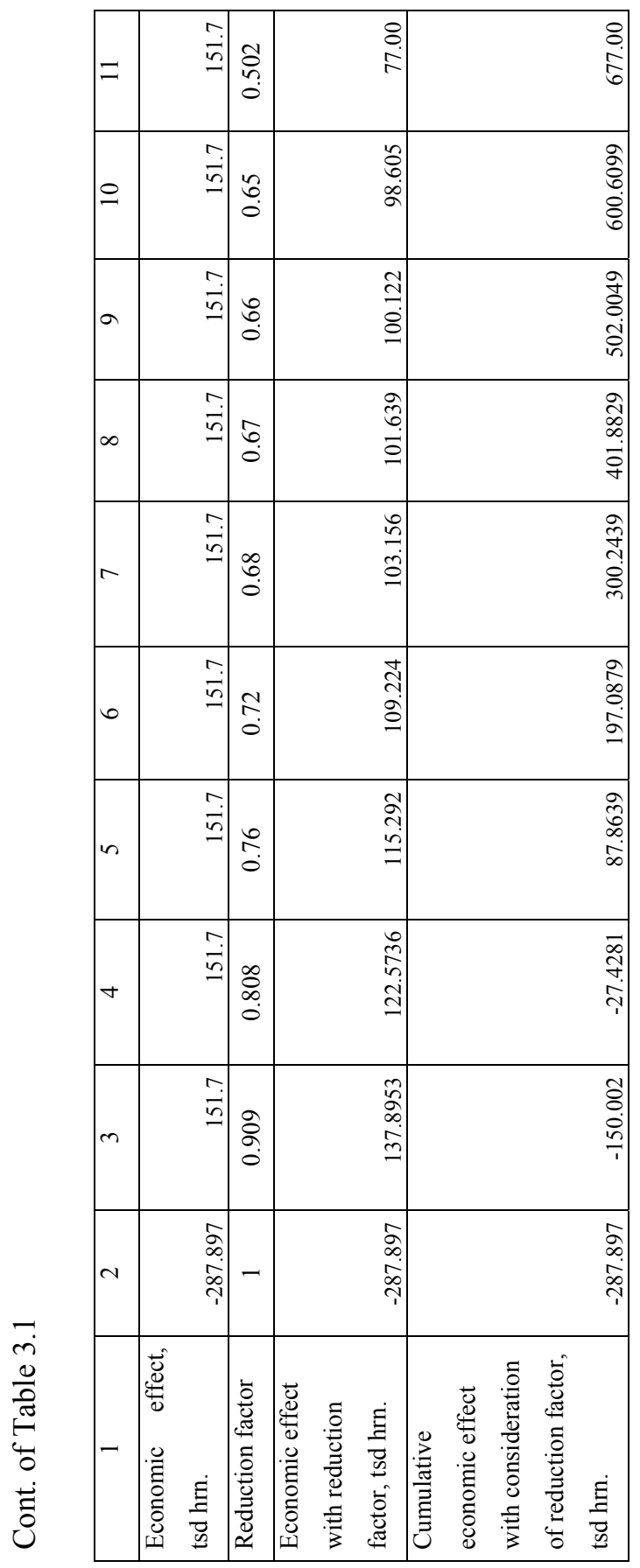




\section{Conclusions to Chapter 3}

1. The presents stages of experimental tests on a full-scale sample, made with consideration of structure, technology and material similar to those of the actual top cord of an open wagon.

2. The modelling of thermal straightening for the testing model was made with the specialized module Cosmos as part of the modelling computer program SolidWorks. It was mentioned that the results of modelling were proved by experimental research of thermal straightening of a full-scale sample of the top cord.

3. This Chapter gives a description of structural transformations in carrying systems of freight wagons at thermal impacts under welding and straightening processes. The study presents the results of optical microscopy for samples of 09G2S and their micro-structures before and after thermal straightening.

4. The study presents the results obtained through testing on the samples made of welding joints. The presented mechanical characteristics of the metal in the heating zone after welding and straightening of a full-scale wagon metal structure confirmed their insignificant deflections from those determined before straightening.

5. The cost-benefit of the improved technology of production and maintenance for freight wagons was estimated. It was established that expectation in terms of economic efficiency of the proposed engineering solutions regarding thermal straightening of freight wagon elements manufactured at Paniutino Wagon Works will account for 677,000 hrn. for 100 open wagons. 


\section{GENERAL CONCLUSIONS}

The presents the solution to an urgent and significant scientific problem of formulating the theoretical basis and providing practical solutions to elimination of production, maintenance and operational deformations of complex structures of freight wagons with the thermal straightening method. Implementation of the proposed techniques will help considerably reduce costs of technological processes of production and maintenance for freight wagons. The basic results, conclusions and recommendations include the following:

1. Analysis of possible deformations in structural components of freight wagons confirmed that the basic reasons for emergence of deformations are violations of operational and technological requirements. Particularly, it was established that over $80 \%$ of deformations in production was caused by breaches of technological welding procedures. Thus, breaches of technology in production of the center sill of universal open wagons can result in deflections of up to $120 \mathrm{~mm}$, which is inadmissible; and breaches of welding technology for the top cord can lead to deflection of about $500 \mathrm{~mm}$ which is inadmissible as well.

2. The classification of straightening techniques developed by the author and intended for wagon structures includes and describes all approaches used today. Among straightening techniques for wagon structures the thermal straightening has certain advantages in terms of economic characteristics.

3. The results of research into physical nature and scope of application of the thermal straightening for wagon metal structures substantiated its efficiency for frame elements. And the highest efficiency can be reached by straightening post-welding deformations in beams and frames of the carrying system.

4. A generalized universal mathematical notation of the thermal straightening process for wagon components is efficient, which is proved by experience in using the corresponding mathematical dependencies developed on its basis.

5. The results of metallographic (structural material transformation) and mechanical research in heating fields of wagon metal structures under thermal straightening grounded a possibility to use thermally straightened elements of freight wagons during their life cycle. It is reasoned by providing a required level of material characteristics, i.e. reducing the yielding level by 6-7.5\%, and change in hardness by $8 \%$. 
6. The developed mathematical dependencies of varied geometric parameters of heating zones under thermal straightening of the center sill and the top cord for universal open wagons are adequate (error is in a range of 7.5 $\%$ ), and their application for elimination of post-welding deformations is efficient.

7. The proposed wedge method is recommended for thermal straightening of center sills and top cords (C-like structures) of universal open wagons. The heating zone has an isosceles triangle form with the top directed to a further deflection area on the beam.

8. The heating fields at thermal straightening of the center sill and the top cord should be marked symmetrically on both sides. The rational parameters of thermal straightening for the center sill are: optimal heating temperature varies in the range from $800{ }^{\circ} \mathrm{C}$ to $850^{\circ} \mathrm{C}$, heating triangle height - from $100 \mathrm{~mm}$ to $120 \mathrm{~mm}$, and width - from $80 \mathrm{~mm}$ to $100 \mathrm{~mm}$. For the top cord: optimal temperature - from $600{ }^{\circ} \mathrm{C}$ to $650^{\circ} \mathrm{C}$, heating triangle height from $50 \mathrm{~mm}$ to $90 \mathrm{~mm}$, and width - from $40 \mathrm{~mm}$ to $80 \mathrm{~mm}$. The number of heating zones varies in the range from 3 to 5 at each side.

9. The additional diagrams developed are advisable to use for a search of optimal geometric parameters of heating zones of the center sill and the top cord of universal open wagons according to the initial deformation deflection. For example, for the center sill at the most popular deflection of $100 \mathrm{~mm}$ the optimal parameters are: heating temperature $800{ }^{\circ} \mathrm{C}$, heating triangle height $\mathrm{h}=107 \mathrm{~mm}$, and width $\mathrm{b}=85 \mathrm{~mm}$. For the top cord at the most popular deflection of $380 \mathrm{~mm}$ the optimal parameters are: heating temperature $600{ }^{\circ} \mathrm{C}$, heating triangle height $\mathrm{h}=78 \mathrm{~mm}$, and width $\mathrm{b}=65$ $\mathrm{mm}$.

10. The proposed thermal straightening techniques for carrying structures of freight wagons are also efficient if used for other metal structure of transport and general engineering. The economic effect from implementation of proposed technical solutions in terms of thermal straightening for structures of open wagons manufactured at Paniutino Wagon Works can reach 677,000 hrn per 100 units. 


\section{References}

1. Цыган Б. Г., Цыган А. Б. Вагоностроительные конструкции. Изготовление, модернизация, ремонт: монографія. Кременчуг: «Кременчуг», 2005. 752 с.

2. Шляпин В. Б., Лозинский В. Н. Сварка на железнодорожном транспорте за последние пятьдесят лет. Сварочное производство. 1988. №1. C. $15-18$.

3. Приходько В. И. Комплексная механизация и автоматизация производственных процессов в вагоностроении. Полтава: Критерий, 1999. $427 \mathrm{c}$.

4. Фомін О. В. Дослідження дефектів та пошкоджень несучих систем залізничних напіввагонів: монографія. Київ: ДЕТУТ, 2014. 299 с.

5.Matsui S. Prevention of Welding Deformations in Thin-Skin Welded Structures. J. of the Light Metal Welding \& Construction. 1982. Vol. 20. No 1. P. $3-11$.

6. Фомін О.В., Бурлуцький О.В. Аналіз факторів, що визначають міцність та надійність кузовів на піввагонів. // Перспективна техніка i технології - 2013: матеріали IX міжнар. наук.-практ. конф. молодих учених, аспірантів і студентів (24-26 вер. 2013, Миколаїв) Миколаїв, 2013. С. 124-131.

7. Фомін О. В., Бурлуцький О. В. Метод оцінки показників надійності елементів кузовів сучасних залізничних напіввагонів 3 урахуванням цензурування вибірки. Зб. наук. праць ДІЗТ УкрДАЗТ. Сер.Технические науки. Донецьк: ДонІЗТ, 2012. Вип. 29. С. 215-221. -(

8. Долматов А.А., Райков Г.В., Костров В.Б. Полувагонам прогрессивный срок службы Ж.-д. трансп. 1982. Вип. № 12. С. 61-63.

9. Николаев Г.А., Рыкалин Н.Н., Николаев Г.А. Деформации при сварке конструкцій. Москва: Издательство СССР, 1948. С. 183.

10. Фомін О. В, О.В. Бурлуцький, В.В.Фомін. Аналіз існуючих підходів до оцінювання втомленості декомпозиційних складових кузовів залізничних на піввагонів. Міцність матеріалів та елементів конструкцій: тези доповідей міжнар. наук.-тех. конф. «Втома та термовтома матеріалів та елементів конструкцій» Ін-ту проблем міцності ім. Г. С. Писаренка 28-31 трав. 2013 Київ. Київ,2013. С. 312-314.

11.Фомін О.В., О.В. Бурлуцький. Особливості методики визначення втомної довговічності напіввагона 3 урахуванням експлуатаційних ушкоджень. Східно-Свропейський журнал передових технологій. Харків, 2013. Вип. 2/7. С. 12-16.

12.Касаткин Б. С., Прохоренко В. М., Чертов И. М. Напряжения и деформации при сварке: учеб. пособ. Москва: Изд.- Выс. шк., 1987. 246 с.

13. Николаев Г. А. Сварные конструкции. Москва: Машгиз, 1953. 536 с.

14. Окерблом Н. О. Расчет деформаций металлоконструкций при сварке. Москва: Машгиз, 1955. 212 с. 
15. Гатовский К. М. Определение сварочных деформаций и напряжений с учетом структуры превращений металла .Сварочное производство. 1973. № 11. С.3-6.

16. Касаткин В. С., Лобанов Л. М. Температурное напряжение в пластине от точечного источника тепла. Автоматическая сварка. 1965. №6. C.6-10.

17. Винокуров В. А., Григорьянц А. Г. Способ определения временных и остаточных напряжений при движении упруго-пластической зоны в пластине при помощи ЦВМ. Изв. вузов. Машиностроение. 1967. № 5. С.149155 .

18.Tell L. Residual Stresses in Welded Plates. A Theoretical Study. The Weldig Journal. 1964. №43. P.123-131.

19.Окерблом Н. О. Конструктивно-технологическое проектирование сварных конструкций. Москва: Машиностроение, 1964. 419 с.

20.Bruce G. J., Yuliadai M. Z., Shahab A. A study on the prediction of ship plate distortion topology by neural networks. Journal of Ship Production. 1999. Vol. 15. No 4. P. 191-197.

21. Lightfoot M. P., Bruce G. J., McPherson N. A., Woods K. The Application of Artificial Neural Networks to Weld-Induced Deformation in Ship Plate. Weld. J. 2005. No 2. P. 23-30.

22. Винокуров В. А. Сварочные деформации и напряжения.- Москва : Машиностроение, 1968. 235 с.

23 Касаткин Б. С., Прохоренко В.М., Чертов И.М Напряжения и деформации при сварке. Київ, : Вища школа, 1987. 246 с.

24 Okerblom N. O. The calculation of deformation of welded metal structure. London : H. M. Stationary Office, 1958.

25 Vinokurov V. A. Welding stress and distortion. Wetherby : British Library, 1977. P. 259-264.

26 Makhnenko V. I., Velikoivanenko E.A., Pochinok V.E., Makhnenko V.O. [et al.] Numerical Methods for the Prediction of Welding Stress and Distortions. Welding and Surfacing Reviews. 1999. Vol. 13. No 1.

27 Ueda Y., Wang J., Murakawa H., Yuan M. Three dimensional numerical simulation of various thermo-mechanical processes by FEM (Report IV). Trans. of JWRI. 1993. Vol. 22. No 2. P. 289-294.

28 Ueda Y., Nakacho K., Yuan M. Application of FEM to theoretical analysis, measurement and prediction of welding residual stresses. Trans. of JWRI. 1991. Vol. 20. No 1. P. 97-107.

29 Трочун И. П. Внутренние усилия и деформации при сварке. Москва: Машгиз, 1964. 180 с.

30 Усадочные напряжения при сварке цилиндрических сосудов / Е. О. Патон, Б. Н. Горбунов, Д. И. Берштейн, К. И. Дзелватовский . Автоген. дело. 1936. № 5. С. $8-14$.

31 Тензометрия в машиностроении: справ. пособие / под ред. Р. А. Макарова. Москва : Машиностроение, 1975. -288 с. 
32 Рыкалин Н. Н. и Фридлянд Л. А. Регулирование твердости и структуры околошовной зоны. Сварочная техника. Москва: Машгиз, 1948. с. 41-70. 128.

33 Ряполов В. А. Разработка технологических основ и специфика модернизации вагонов - цистерн для обеспечения безопасности их эксплуатации и продления срока службы: дисс. канд. техн. наук.: 05.03.08 Барнаул, 1999. 210 с.

34.Шоршоров М. Х., Белов В. В. Фазовые превращения и изменение свойств стали при сварке: атлас. Москва: Наука, 1972. 219 с.

35. Акулов А. И., Бельчук Г. А., Демянцевич В. П. Технология и оборудование сварки плавленим: учеб. для студентов вузов. Москва: Машиностроение, 1977. 432 с.

36. Шляпин В. Б., Павленко А.Ф., Емельянов В.Ю. Ремонт вагонов сваркой: Справочник. Москва: Транспорт, 1983. 246 с.

37. Лившиц Л. С., Хакимов А. Н. Металловедение сварки и термическая обработка сварных соединений. Москва: Машиностроение, 1989. $331 \mathrm{c}$.

38. Гривняк И. Свариваемость сталей. Москва: Машиностроение, 1984. 216 c.

39. Б.Е.Патон, Лобанов Л.М., Самилов В.Н., Пилишенко И.С., Горинов В.А., Махненко О.В. и [др.] Крупногабаритная сварная конструкция преобразуемого объема. Автомат. Сварка. 2006. № 7. C. 3-14.

40. J. M. G. Duhamel. Mémoire sur le calcul des actions moléculaire développées par les changements de tempé rature dans les corps solides, «Mémoires présentées... par div. sav. à l'Ac ad. des sciences.» T. V. 1838

41. Динник А. Н. Приложение функций Бесселя к задачам теории упругости. Екатеринослав 1915. с. 94.

42] Мусхелишвили Н. И. Некоторые задачи теории упругости. Ленинград,1933.c. 163-174.

43 Галеркин Б. Г. Термические напряжения в упругих пластинах. Упругие тонкие плиты. Москва: Госстройиздат, 1933. с. 344-362.

44 Коваленко А. Д. Термоупругость пластин и оболочек. Киев: Институт механики АН УССР, Киев. гос. ун-т. 1971. 108 с.

45 Коваленко А. Д. Термоупругость. Киев: Вища школа, 1975. 216 с.

46 Речкалов С. Д. Напряженно-деформированное состояние сварных элементов кузова вагона для сыпучих металлургических грузов с учетом температурных воздействий : дис. канд. техн. наук. Москва, 1987. 295 с.

47 Даниленко Д. В., Намятов А. В., Лапшин В. Ф Модель термонагруженности вагона-термоса для транспортировки горячих металлургических заготовок. Транспорт Урала. 2013. № 2. с. 24 - 29.

48 Прохоренко О. В. Залишковий прогин хребтової балки вагона від зварювання поздовжніх швів. Технологические системы. 2009. № 4(48). С. $82-93$. 
49 Прохоренко О. В. Нова концепція запобігання залишкового прогину хребтової балки вагона від зварювання поздовжніх швів. Технологические системы. 2010. № 2(51). С. 58-63.

50]Бурлуцький О. В., Кочешкова Н.С. Визначення зварювальних деформацій які виникають під час життєвого циклу на піввагона. Зб. наук. праць ДЕТУТ. Серія Транспортні системи і технології. Київ: ДЕТУТ, 2015. № 26-27. C. 92-101.

51 Camilleri D., Gray T. J. Optimisation of welded lightweight multiplestiffener plate structures to minimise unwanted shape distortions. Welding and Cutting. 2006. Vol. 5. No 6. P. $320-327$.

52 Deng D. Theoretical Prediction and Control of Welding Distortion in Large Structures Considering Positioning and the Gap between Parts. Trans. JWRI. 2003. Vol. 32. P. 219-222.

53 Проектирование сварной надрессорной балки грузовых полувагонов / В. И. Махненко, Э. Ф.Гарф, С. Т.Римский, В. И.Галинич, О. В. Махненко и [др.]. Автомат. Сварка. 2006. №4. С. 3-10.

54 Мелюков В. В., Труфакин А. И., Чирков А.М. Моделирование оптимального теплового режима лазерной сварки кольцевого соединения малого діаметра. Технология машиностроения. 2005. № 9. С. 58-62.

55 Pavlovsky V. I., Masubuchi K. Residual Stresses and Distortion in Welded Structures WRC Bulletin. 1994. No 338.

56 Michaleris P., Sun X. Finite Element Analysis of Thermal Tensioning Techniques Multigating Weld Buckling Distortion. Weld. J. 1997. Vol. 76. No 11. P. 451-457.

57. Michaleris P., Dantzig J., Tortorelli D. Minimization of Welding Residual Stress and Distortion in Large Structures. Weld. J. 1999. No 11. P. 361366.

58 Shaoqing G., Wenli X., Xuesong L. [et al.] Finite Element Analysis of Welding Distortion Control by Trailing Intense Cooling. J. China welding. 2000. Vol. 9. No 2. P. 127-134.

59 Кауфман Г. Эффективное производство профилей для судостроения. Svetsaren. 2003. No 1. P. 9-15

[60] Park J. U., Park S. C., Lee C. H. Control of Longitudinal Bending Distortion of Built-Up Beams by High-Frequency Induction Heating. Weld. J. 2009. No 2. P. 29-34.

61 Механіка руйнування і міцність матеріалів: довідн. посібник / за заг. ред. В. В. Панасюка. Т. 8: Міцність матеріалів і довговічність конструкцій атомних електростанцій / О. І. Балицький, О. В. Махненко, О.О.Балицький, В. А. Грабовський, Д. М. Завербний, Б. Т. Тімофеєв; за ред. О. І. Балицького Київ: ВД „Академперіодика”, 2005. 541с.

62. Schaumann P., Keindorf C., Zacke S. Numerische Eigenspannungsermittlung an einer einlagig geschweißten Stumpfnaht mit anschließender UIT-Behandlung Schweißen und Schneiden. 2007. Vol. 59. No11. S. 590-599. 
63 Автоматизированная термическая правка сварных тонколистовых конструкцій / Б. Е. Патон, Л. М. Лобанов, Г. А. Цыбулькин, О. В. Махненко, Н. П. Переверзев. Автомат. сварка. 2003. № 7. С. 3-8.

64 Махненко О. В., Мужиченко А.Ф. Математическое моделирование тепловой правки цилиндрических оболочек и валов с общими деформациями искривления продольной оси. Автомат. сварка. 2007. № 9. С. 23-28.

65 Фомін О. В., Бурлуцький О.В., Горбунов М.І., Логвіненко О.А., Фоміна А.М. Термічна правка технологічно-деформованих верхніх обв'язувань на піввагонів. Вісник НТУ «ХПІ». Сер. Динаміка та міцність машин. Харків: НТУ(ХПІ), 2017. № 39(1261). С. 76-78.

66 Фомін О.В., Бурлуцький О.В., Логвіненко О.А. Процедура правки технологічно-деформованих вагонних металоконструкцій шляхом створення внутрішнього напруженого стану термічним впливом. Вісник Східноукр. нац. ун-ту імені Володимира Даля. Северодонецьк: СНУ ім. В. Даля, 2017. N 3(233). C. 234-238

67 Burlutskyi O. V. Application methods changes plastic deformation after welding sill gondola cars. Metallurgical and mining industry (Machine building). Dnipropetrovsk, 2015. No.10. P. 190-197

68 Бурлуцький О. В., Логвіненко О.А. Застосування математичного моделювання процесів правки при виготовленні елементів на піввагонів. Зб. наук. праць ДЕТУТ сер Транспортні системи і технології. Київ: ДЕТУТ, 2016. № 28. С. 110-123.

69 Бурлуцький О.В., Кочешкова Н.С. Визначення зварювальних деформацій які виникають під час життєвого циклу на піввагона. Зб. наук. праць ДЕТУТ сер Транспортні системи і технології. Київ: ДЕТУТ, 2015. № 26-27. С. 92-101.

70 Шишкин В. Ю., Храмов П.А. Приближенный метод расчета укорочения элементов металлоконструкций. Прогрессивные методы обработки металлоконструций: Сборник - Ленинград: Ленинградский дом научно-технической пропаганды, 1968. 25 с.

71 Пасек В. В. Сочетание применения АВМ и ЭВМ для исследования температурных деформаций и напряжений при термической правке сварных мостовых конструкцій. Применение машинных методов для решения краевых задач: тезисы докладов Всесоюзной научно-технической конференции. - Москва: Сов. Радио, 1976. с.10.

72 Варетник Л. Д. Правка сварных конструкцій. Харьков: Прапор, 1966. 50 c.

73 Махненко О. В. Прогнозування деформацій при зварюванні i термічному правленні конструкцій на осонові методів термопластичності і функції усадки: автореф. дис. ... д-ра техн. наук: 05.03.06 / НАН України; Ін-т електрозварювання ім. С. О. Патона. К., 2009. 40с.

[74] Мороз В.І., Братченко О.В., Ліньков В.В Основи конструювання і САПР: навч. посіб. Харків: Нове слово, 2003. 194 с. 
[75] Дитрих Я. Проектирование и конструирование: системный поход Москва: Мир, 1981. 456 с.

[76] Герасимов В. С., Скиба И.Ф., Кернич Б.М. и [др.] Технология вагоностроения и ремонта вагонов: учеб. для вузов под ред. В. С. Герасимова. 2-е изд., перераб. и доп. Москва: Транспорт, 1988. 381с.

[77] Сагалевич В. М. Методы устранения сварочных деформаций и напряжений. В.М. Сагалевич. - М.: Машиностроение, 1974. - 248 с.

[78] Вершинский С.В. Проектирование сварных конструкций в машиностроении / под ред. С. А. Куркина. Москва: Машиностроение, 1975. $376 \mathrm{c}$.

[79] ГОСТ 24.050.34-84. Проектирование и изготовление стальных сварных конструкций вагонов. Технические требования. Введ. 1988-01-01. Москва: Изд-во стандартов, 1988. $183 \mathrm{c}$.

[80] Сварка. Резка. Контроль: справочник: в 2 т. / Н. П. Алёшин, Г. Г. Чернышов, Э. А. Гладков и [др.]; под общ. ред. Н. П. Алёшина, Г. Г. Чернышова. Москва: Машиностроение, 2004. 624 с.

[81] Bergmann H.W., Hilbinger R.M. Numerical simulation of centre line not cracks in laser beam welding of aluminium close to the sheet edge. / H.W.Bergmann, // Mathematical Modeling of Weld Phenomena. London: The Institute of Materials, IOH Communications Ltd, 1998. P. 658-668

[82] Рубинштейн Л. И. Проблема Стефана. Рига: Звайгзне, 1967. 458 с.

[83] Фомін О.В., Логвіненко О. А., Дьомін Р. Ю., Фомін В. В., Бородай Г. П., Бурлуцький О. В. Математичні моделі зміни основних показників базових несучих елементів кузовів на піввагонів. Залізничний транспорт України. Київ: ДП «ДНДЦ УЗ», 2013. № 5/6(102/103). С. 95-104.

[84] Бурлуцький О. В. Особливості методу визначення динамічного навантаження кузова напіввагона Вост.-Европ. журн. передовых технологий. Харків, 2012. Вип. 4/7. С. 47-50.

[85] Фомін О. В., Логвіненко О.А., Бурлуцький О.В. Наукове обгрунтування вибору геометричних параметрів зон нагрівання при термічній правці елементів несучих систем вантажних вагонів. Вісник Східноукр. нац. ун-ту імені Володимира Даля. Северодонецьк: СНУ ім. В. Даля, 2017. N 4(234). С. 227-232.

[86] Спосіб термічної правки хребтової балки напіввагона пат. 118285 U Україна, МПК B61F 1/02, B61D 3/00./ Фомін О. В., Логвіненко О. А., Бурлуцький О.В.(Україна). № 201702689; заявл. 22.03.2017; опубл. 25.07.2017, Бюл. № 14 .

[87] Фомін О. В., Бурлуцький О. В. Уточнений метод для дослідження напруженого стану хребтової балки. Aktualne problemy nowoczesnych nauk 2012: Materialy VIII Międzynarodowej naukowi-praktycznej konferencji Vol. 45. Techniczne nauki.:Przemyśl.Nauka i studia C. 42-43

[88] Фомін О. В., Бурлуцький О. В., Горбунов М.І., Логвіненко О.А., Фоміна А.М. Математичне модулювання варіаційних характеристик плям нагрівання при термічній правці каркасних елементів на піввагонів. Зб. наук. 
праць ДУЗТ Серія Транспортні системи і технології. Київ: ДЕТУТ, 2018. № 31. C. 186-195.

[89] Fomin O., Logvinenko O., Burlutskyi O. Synopsis Of The Thermal Method For Straightening Technological-Deformed Car Parts. Globalization of scientific and educational space. Innovations of transport. Problems, Experience, Prospects: Theses of international scientific conference (3-12 May 2017, Dresden Paris) Severodonetsk: Volodymyr Dahl East Ukrainian National University, 2017. P. 201-204.

[90] Спосіб термічної правки обв'язування верхнього напіввагона патент України на корисну модель №122862, МПК (2017.01) B21D 1/00 B61D 3/00 / Фомін О. В., Горбунов М. І., Бурлуцький О. В., Логвіненко О. А., Фоміна А. М (Україна). № u 2017 08878; заявка 05.09.2017 ; публ. 25.01.2018, Бюл. № 2.

[91] Фомін О. В., Бурлуцький О.В., Логвіненко О.А. Особливості використання математичних моделей для отримання характеристик плям нагрівання при термічній правці несучих систем вантажних вагонів. Проблеми розвитку транспорту і логістики: збір тез VII-ї міжнар наук-практ. конф. (26-28 квіт. 2017, м. Одеса / ОНМУ) Северодонецьк: СНУ ім. В. Даля, 2017. C.113- 115

[92] Фомін О.В., Бурлуцький О.В., Горбунов М.I., Логвіненко О.А., Фоміна А.М. Математичні моделі варіації характеристик пятен нагрівання при термічній правці верхніх обв'язувань напіввагонів. Логістичне управління та безпека руху на транспорті: зб тез міжнар. наук.-техн. конф. (5-7 жовт. 2017,. м. Лиман (Україна)) - Северодонецьк: СНУ ім. В. Даля, 2017. C.180-184.

93 Бурлуцький О. В., Фомін О.В., Горбунов М.І., Логвіненко О.А. Допоміжний графік для визначення геометричних параметрів плями нагрівання типу "клин" при термічній правці несучих вагоно-конструкцій. Aktuální vymoženosti vědy - 2017: Materialy XIII mezinárodní vědecko praktická konference, (22 - 30 června 2017 ). On Technické vědy . Moderních informačních technologií .Vol. 6. Geografie a geologie Matematika Moderních informačních technologií Technické vědy. Praha. C. 24-27.

94. Логвіненко,О.А. Особливості технологічного контролю при виготовленні основних елементів конструкцій рухомого складу [Текст] / О.А. Логвіненко, О.В. Бурлуцький,// Матеріали 79-ї науково-технічної конференції «Розвиток наукової та інноваційної діяльності на транспорті» УкрДУЗТ 2017 Зб. наук. праць. - Харків: УкрДУЗТ, 2017. - Вип. 169. - С. 131-134.

95 Фомін О.В. Термічна правка технологічно-деформованих верхніх обв'язувань напіввагонів [Текст] / О.В. Фомін, О.В. Бурлуцький, M.I. Горбунов, О.А. Логвіненко, А.М. Фоміна // Вісник НТУ «ХПІ». Серія: Динаміка та міцність машин. - Харків: НТУ(ХПІ), 2017 -№ 39(1261) - С. 7678. - Режим доступу: DOI: https://doi.org/10.20998/20789130.2017.39.115771(включений до міжнародної науково метричної бази 
Index Copernicus ,Index Copernicus Value та Ulrich's Periodicals Directory (New Jersey, USA))

96. Solid Works компьютерное моделирование в современной практике / Алямовский А. А., Собачкин А. А., Одинцов Е. В., Харитонович А. И., Пономарев Н. Б. - СПб.: БХВ-Петербург, 2005. - 800 с.

97. Fomin, O.V. (2011) Modernization of elements wall lateral of universal freight gondola domestic production// Scientific-and-technical (Sci.Tech.) collected works - Donetsk: DonIZT,. - Vol. No. 26.- pp.111-115 [in Ukrainian]

98. Fomin, O., Kulbovsky, I., Sorochinska, E., Sapronova, S., Bambura, O. (2017). Experimental confirmation of the theory of implementation of the coupled design of center girder of the hopper wagons for iron ore pellets. EasternEuropean Journal of Enterprise Technologies, 5 (1 (89)), 11-18. doi: https://doi.org/10.15587/1729-4061.2017.109588

99. Fomin, O.V., Gostra, A. V. (2015) Variacijne opisannja konstruktivnih vikonan' vantazhnih vagoniv [Variations describe the structural designs of freight cars] Proceedings of the State Economic and Technological University of Transport, Ministry of Education and Science of Ukraine series "Transport systems and technologies", Vol. 26-27, 137-147 [in Ukrainian].

100. Makarenko, M. V. (2014) Kompleksnyi analiz ekonomichnoho efektu vid zhyttievoho tsyklu suchasnoho napivvahonu [Comprehensive analysis of the economic impact of the life cycle of a modern gondola]. Naukovo-praktychnyi zhurnal «Zaliznychnyi transport Ukrainy» - Scientific and Practical Journal "Railway Transport of Ukraine", Vol 5, 107 [in Ukrainian].

101. Turpak, S.M. Logistic technology to deliver raw material for metallurgical production / S.M. Turpak, I.O. Taran, O.V. Fomin, O.O. Tretiak// // Scientific Bulletin of National Mining University . 2018, Issue 1, p.162-169 DOI: $10.29202 / \mathrm{nvngu} / 2018-1 / 3$

102. Moroz, V.I. (2009) Matematychnyy zapys zadachi optymizatsiynoho proektuvannya piv-vahoniv za kryteriyem minimal'noyi materialoyemnosti [Mathematical notation of problem of optimizing design of open goods wagons by criterion of the minimum material capacity]. Zbirnyk naukovykh prats - Collection of scientifc papers, Vol. 111, 121-131 [in Ukrainian].

103. Shvets, A. O. (2018). Influence of the longitudinal and transverse displacement of the center of gravity of the load in gondola cars on their dynamic indicators. Science and Transport Progress, 5(77), 115-128. doi: 10.15802/stp2018/146432 (in Ukrainian)

104. Lovska A., Rybin A. (2015). The study of dynamic load on a wagonplatform at a shunting collision. Eastern-European Journal Of Enterprise Technologies, 3, 4-8.

105. Sapronova, S., Tkachenko, V., Fomin, O., Hatchenko, V., Maliuk, S. (2017). Research on the safety factor against derailment of railway vehicles. 
Eastern-European Journal of Enterprise Technologies, 6 (7 (90)), 19-25. doi: https://doi.org/10.15587/1729-4061.2017.116194

106. Lukhanin N. I., Myamlin S. V., Neduzhaya L. A., Shvets A. A. Dinamikagruzovykhvagonov $\mathrm{S}$ uchetompoperechnogosmeshcheniyatelezhek [Freight cars dynamics, taking into account transversal displacement of the bogies]. Zbirnyknaukovykh prats Donetskohoinstytutuzaliznychnohotransportu [Proc. of the Donetsk Railway Transport Institute], 2012, issue 29, pp. 234-241. (in Russian).

107. Fomin, O. Determining strength indicators for the bearing structure of a covered wagon's body made from round pipes when transported by a railroad ferry [Text] / O. Fomin, A. Lovska, V. Masliyev, A. Tsymbaliuk, O. Burlutski // Eastern-European Journal of Enterprise Technologies. - 2019. - Vol. 7, Issue 1 (97). - P. 33-40. doi: 10.15587/1729-4061.2019.154282

108. Fomin, Oleksij, Juraj Gerlici, Alyona Lovska, Kateryna Kravchenko, Pavlo Prokopenko, Anna Fomina, and Vladimir Hauser. "Durability Determination of the Bearing Structure of an Open Freight Wagon Body Made of Round Pipes during its Transportation on the Railway Ferry." Communications-Scientific letters of the University of Zilina 21, no. 1 (2019): 28-34.

109. Fomin, O. Determining the dynamic loading on a semi-wagon when fixing it with a viscous coupling to a ferry deck [Text] / O. Fomin, A. Lovska, I. Kulbovskyi, H. Holub, I. Kozarchuk, V. Kharuta // Eastern-European Journal of Enterprise Technologies. - 2019. - Vol. 8, Issue 2/7 (98). - P. 6-12. doi: $10.15587 / 1729-4061.2019 .160456$

110. Fomin, O. V. (2015) Vprovadzhennya kruglih trub v nesuchI sistemi napIvvagonIv z zabezpechennyam ratsIonalnih pokaznikIv mItsnostI [Introduction of round pipes in the carrier systems of gondolas with the provision of rational indicators of strength]. Naukoviy zhurnal - «Tehnologicheskiy audit i rezervyi proizvodstva» - Sceince magazine - "Technological audit and production reserves", Vol. 4/1(21), 83-89 [in Ukrainian].

111. Okorokov, A., Fomin, O., Lovska, A., Vernigora, R., Zhuravel, I., Fomin, V. (2018). Research into a possibility to prolong the time of operation of universal open top wagon bodies that have exhausted their standard resource. Eastern-European Journal of Enterprise Technologies, 3 (7 (93)), 20-26. doi: https://doi.org/10.15587/1729-4061.2018.131309

112. Tkachenko, V. Research of resistance to the motion of vehicles related to the direction by railway [Text] / V. Tkachenko, S. Sapronova, I. Kulbovskiy, O. Fomin // Eastern-European Journal of Enterprise Technologies. - 2017. - Vol. 5, Issue 7 (89). - P. 65-72. doi: 10.15587/1729-4061.2017.109791

113. Fomín O.V. Matematicheskiye modeli osnovopolagayushchikh pokazaniy bazovykh nesushchikh elementov kuzova / O.V. Fomín, O.A. Logvínenko, R.YU. D'omín, G.P. Boroday, V.V. Fomín, O.V. Burluts'kiy // 
Naukovo-prakticheskiy zhurnal «Zalíznichniy transport Ukraïni». - Kiïv: DNDTS UZ, 2013. - № 5/6 (102/103). - S. 95-104.

114. Kondratiev A. Method for determining the thickness of a binder layer at its non-uniform mass transfer inside the channel of a honeycomb filler made from polymeric paper [Text] / A. Kondratiev, M. Slivinsky. - Eastern-European Journal of Enterprise Technologies. - 2018. - Vol 6/5 (96). - Pp. 42 - 48. DOI: $10.15587 / 1729-4061.2018 .150387$ 




\section{CONTROLLED HEAT STRAIGHTENING FOR THE ROLLING STOCK STRUCTURES TO RESTORE THEIR SERVICEABILITY}

Collective monograph 